INSTITUTO DE PESQUISAS ENERGÉTICAS E NUCLEARES

Autarquia associada à Universidade de São Paulo

CONTRIBUIÇÃO À LEGISLAÇÃO BRASILEIRA NO SETOR DE

ENERGIA NUCLEAR

JOSÉ ALBERTO MAIA BARBOSA

Tese apresentada como parte dos requisitos para obtenção do Grau de Doutor em Ciências na Área de Tecnologia Nuclear - Aplicações.

Orientador:

Dr. Gian-Maria Agostino Angelo Sordi

Co - orientador:

Dr. Leandro Del Moral Ituarte 
Dedico este trabalho científico à Lorene Aparecida Norte da Silva, por ter estado ao meu lado, em todos os momentos desta jornada, principalmente nos de maior dificuldade, com palavras de carinho, incentivo e sabedoria, que me deram força e segurança para trilhar o caminho até o seu final, onde a distância não foi fronteira para o grande afeto que nos une. 


\section{AGRADECIMENTOS}

Quero agradecer as seguintes instituições e pessoas que contribuíram de maneira relevante para o meu ingresso, realização e conclusão no Programa de PósGraduação em Tecnologia Nuclear em nível de Doutorado do Instituto de Pesquisas Energéticas e Nucleares.

À Universidade de São Paulo, por promover e desenvolver todas as formas de conhecimento, por meio do ensino e da pesquisa, visando à formação de pessoas capacitadas ao exercício da investigação e do magistério em todas as áreas do conhecimento, bem como à qualificação para as atividades profissionais.

Ao Instituto de Pesquisas Energéticas e Nucleares, pelos ensinamentos transmitidos, pela oportunidade de convivência com profissionais da mais alta competência e pelos recursos tecnológicos colocados ao meu dispor para realização da pesquisa e desenvolvimento deste estudo.

Ao Banco Santander, pela bolsa de estudos do Programa de Mobilidade Internacional de Pós-Graduandos da Universidade de São Paulo (USP), que me permitiu a realização de um estágio na Universidad de Sevilla na Espanha.

Ao Doutor Gian-Maria Agostino Angelo Sordi, por ter aceitado ser meu orientador junto ao Programa de Pós-Graduação, que, nos anos de convivência, muito me ensinou, contribuindo para meu crescimento científico e intelectual, compartilhando todo o seu conhecimento técnico-científico, que foram fundamentais, para o desenvolvimento e conclusão do presente estudo e principalmente por sua preciosa amizade. 
Aos Doutores José Esteban Castro, Leandro Del Moral Ituarte e Álvaro Avelino Sánchez Bravo, facilitadores e responsáveis pelo meu intercâmbio de conhecimentos na Universidad de Sevilla na Espanha, essenciais para a complementação de minha formação acadêmica.

À Doutora Magda Vieira da Silva, pela sua participação na Comissão julgadora do meu exame de capacidade, e seus comentários críticos ao Plano de trabalho.

À Mestra Selma Violato Frazão, pelas aulas particulares das disciplinas de fundamentos de tecnologia nuclear e por sua valiosa amizade.

À Doralice de Lima Xavier, pela gentil acolhida em Sampa, período que me permitiu assistir aulas importantes sobre temas abordados no presente estudo.

À Marlene Cestarolli, pelo seu amor, carinho, presença constante, dedicação, incentivo e apoio incondicional, oferecidos durante minha estada na Espanha e nos derradeiros meses de conclusão da Pós-Graduação.

Aos meus irmãos Eduardo Ribeiro Barbosa e Isabel Cristina Maia Barbosa, pelo apoio constante nas tarefas cotidianas, me proporcionando tempo para total dedicação aos estudos da Pós-Graduação.

À minha mãe Alice Aparecida Maia Barbosa. 


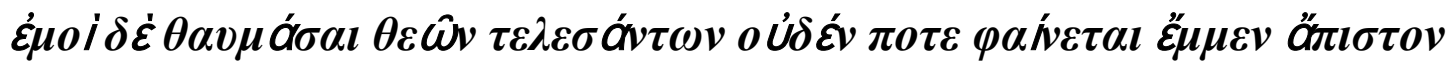

"Para mim, quando os deuses realizam maravilhas, nada parece inacreditável" Píndaro, Pi. P. 10.48-50 


\title{
CONTRIBUIÇÃO À LEGISLAÇÃO BRASILEIRA NO SETOR DE ENERGIA NUCLEAR
}

\author{
José Alberto Maia Barbosa
}

\begin{abstract}
RESUMO
Tecnologia nuclear, ter o seu domínio é, considerado nos dias de hoje, um diferencial para um país frente aos demais, podendo representar uma ameaça internacional a ser contida ou um aspecto de valorização tecnológica e política para aqueles cuja credibilidade internacional é reconhecida. Diante do uso crescente de novas tecnologias no setor e a necessidade de uma regulamentação, de acordo com os padrões de segurança internacionais, para assegurar a sua utilização, o objetivo desse estudo foi demonstrar se a radioproteção ocupacional e ambiental praticada em nosso país está de acordo com os padrões internacionais de segurança radiológica e nuclear. Para tanto, foi atualizada e revisada a legislação brasileira na área da energia nuclear comparando-a com as da União Europeia, contextualizados os pontos fortes e os pontos fracos da legislação nacional, apontadas críticas e sugestões para que reformas sejam realizadas visando a sua adequação aos padrões internacionais. A hipótese considerada demonstrou que mudanças na estrutura de regulação do setor nuclear brasileiro são necessárias, visando à criação de uma agência reguladora de atividades nucleares, com o intuito de assegurar que o estado da arte e da tecnologia, em termos de segurança nuclear, seja a base do exercício de suas atividades normativas de fiscalização e de avaliação de segurança na preservação do meio ambiente, da saúde do público e dos trabalhadores, frente às aplicações da energia nuclear.
\end{abstract}




\title{
CONTRIBUTION TO THE BRAZILIAN LEGISLATION IN NUCLEAR ENERGY FIELD
}

\author{
José Alberto Maia Barbosa
}

\begin{abstract}
Nuclear technology: to keep its domain is actually considered a differential for a country in relation to other ones, being able to represent an international threat to be contained or an aspect on technological and political valorization for those ones with recognized international credibility. Face to a raising use of new technologies in the field and the requirement asking for regulation in accordance with international safety standards, in order to assure its employment, the objective of this study was to demonstrate whether occupational and environmental radioprotection performed in our country is within radiological and nuclear safety international standards, and so it was updated and revised the Brazilian law in nuclear energy area, by comparing it with European Union, contextualized strong and weak points from national law, indicating criticisms and suggestions, in order that modifications will be able to be accomplished, aiming to its adequacy to international standards. The considered hypothesis showed that are required changes in the regulation structure in Brazilian nuclear area, aiming to the creation of a regulator agency of nuclear activities, with the purpose of assuring that the state of art and of technology, in terms of nuclear safety, to be the basis of the exercise related to their normative, control and safety assessment activities, on environment preservation, public and workers health, face to nuclear energy applications.
\end{abstract}




\title{
BEITRAG ZUR BRASILIANISCHEN GESETZGEBUNG IM BEREICH DER KERNENERGIE
}

\author{
José Alberto Maia Barbosa
}

\section{ZUSAMMENFASSUNG}

Die Beherrschung der Kernenergie wird heutzutage als eine Besonderheit gegenueber andere Laender betrachtet, sie kann als eine internationale zurueckzuhaltende Bedrohung oder als ein Aspekt der technologischen und politischen Bewertung fuer die, deren internationale Glaubwuerdigkeit anerkannt wird, darstellen. Angesichts der wachsenden Nutzung neuer Technologien in diesem Bereich und der Notwendigkeit einer Regelung in Uebereinstimmung mit den internationalen Sicherheitsnormen um ihre Benutzung sicherzustellen, ist das Ziel dieser Studie vorzuweisen, ob die in unserem Land angewendete Radio-Beschuetzung mit den internationalen Normen fuer Radiologie-und Kernenergie-Sicherheit uebereinstimmt. Dafuer wurde die brasilianische Regelung im Bereich der Kernenergie aktualisiert, nachgeprueft. und mit denen der EU verglichen. Dabei wurden die Schwachpunkte und die Staerken der nationalen Gesetzgebung in Betracht gezogen, auf Vorschlaege und Kritiken hingewiesen, damit die notwendigen Reformen in Uebereinstimmung mit den internationalen Normen, durchgefuehrt werden koennen. Die beruecksichtigte Hypothese zeigt, dass Aenderungen in der Regelung des brasilianischen Kernenergie-Bereichs notwendig sind mit der Absicht eine Agentur zur Regulierung der Kernenergie-Aktivitaeten zu erschaffen. Damit wird beabsichtigt, sicherzustellen, dass das Kunst-und Technologiewesen in Bezug auf KernenergieSicherheit die Grundlage ist, zur Ausuebung ihrer normativen Aktivitaeten bei der Kontrolle und Bewertung der Sicherheit, in der Erhaltung der Umwelt, der Gesundheit des Volkes und der Arbeiter bei der Kernenergie-Benutzung. 


\section{SUMÁRIO}

Página

1 INTRODUÇÃO 12

1.1 Energia Nuclear: Os desafios para o futuro 12

1.2 Principais razões que levaram o autor a realizar a pesquisa 13

1.3 A importância do problema levantado 13

1.3.1 O problema da pesquisa 13

1.3.2 Hipótese básica 13

1.4 Alcance da pesquisa e delimitação do assunto 14

1.5 Relação do trabalho com outros similares 15

2 FINALIDADE, OBJETIVOS E JUSTIFICATIVA 16

2.1 Finalidade 16

2.2 Objetivos 16

2.3 Justificativa 16

3 METODOLOGIA 18

4 A HISTÓRIA DA ENERGIA NUCLEAR NO BRASIL 20

4.1 Primórdios da energia nuclear no Brasil 20

4.2 Uma política nuclear nacional 22

4.3 Primeira usina nuclear brasileira 22

4.4 Implantação de centrais nucleares 23

4.5 Rompimento das negociações com os americanos 23

4.6 Acordo Brasil - Alemanha 25

4.7 Avaliação do PNB pós-governos militares 26

4.8 Programa Nuclear Autônomo 28

4.9 Viabilização econômica das usinas Angra 2 e Angra 3

4.10 Retomada do PNB e a conclusão de Angra 3

5 ORDENAMENTO JURÍDICO E INSTITUCIONAL NACIONAL 36

5.1 Ordenamento jurídico 36

5.2 Processo legislativo 36

5.3 Atos administrativos 38

5.4 Constituição Brasileira e o Direito Nuclear 41 
5.5 Legislação infraconstitucional brasileira

5.6 Legislação Internacional 49

6 MARCO REGULATÓRIO 51

6.1 Regulação na área Nuclear 51

6.2 Regulação nuclear no Brasil 51

6.3 Controle regulatório exercido no Brasil 52

7 FORMAÇÃO DO ESPAÇO EUROPEU

7.1 Principais instituições encarregadas da legislação e das políticas comunitárias 55

7.1.1 Parlamento Europeu 55

7.1.2 Conselho da UE

7.1.3 Comissão Europeia 56

7.2 Ordenamento jurídico 58

7.2.1 Tratados 58

7.2.2 Acordos internacionais 58

7.2.3 Acordos com países terceiros ou organizações internacionais 59

7.2.4 Acordos entre os Estados-Membros 59

$\begin{array}{ll}\text { 7.2.5 Direito derivado } & 60\end{array}$

$\begin{array}{ll}\text { 7.2.6 Regulamento } & 60\end{array}$

$\begin{array}{ll}\text { 7.2.7 Diretiva } & 60\end{array}$

$\begin{array}{ll}\text { 7.2.8 Decisão } & 60\end{array}$

$\begin{array}{ll}\text { 7.2.9 Recomendação } & 61\end{array}$

$\begin{array}{ll}\text { 7.2.10 Parecer } & 61\end{array}$

7.2.11 Ação comum $\quad 61$

7.2.12 Decisão, decisão-quadro e ação comum 61

7.2.13 Posição comum 62

7.2.14 Acordo internacional $\quad 62$

7.2.15 Jurisprudência $\quad 62$

7.2.16 Princípios gerais de direito $\quad 62$

7.2.17 Tribunal de Justiça das Comunidades Europeias 62

8 PANORAMA DA ENERGIA NUCLEAR NA EUROPA 64

$\begin{array}{ll}\text { 8.1 Origem } & 64\end{array}$

$\begin{array}{ll}\text { 8.2 Objetivos } & 65\end{array}$

$\begin{array}{ll}8.3 \text { Âmbito de aplicação } & 66\end{array}$ 
8.4 Regime jurídico $\quad 66$

$\begin{array}{ll}\text { 8.5 Estrutura } & 67\end{array}$

$\begin{array}{lc}\text { 8.6 Missões } & 68\end{array}$

8.7 Futuro do Tratado Euratom 71

8.8 Gestão dos riscos ligados à energia nuclear 72

8.9 Proteção contra as radiações $\quad 73$

8.10 Investigação europeia no domínio nuclear 74

8.11 Energia nuclear e competitividade 75

9 DISCUSSÃO

10 CONCLUSÕES 92

11 FUTUROS TRABALHOS 95

APÊNDICE - CONSOLIDADO DA LEGISLAÇÃO NA ÁREA NUCLEAR 96

GLOSSÁRIO 129

$\begin{array}{ll}\text { REFERENCIAS } & 137\end{array}$

BIBLIOGRAFIA RECOMENDADA 141 


\section{INTRODUÇÃO}

\subsection{Energia Nuclear: Os desafios para o futuro}

O século XXI deverá ser o século da energia nuclear, não apenas sob as formas que já vêm sendo exploradas pela humanidade há mais de meio século, mas também com os avanços proporcionados pelo crescente conhecimento dos processos que ocorrem no núcleo atômico, os quais prometem expandir as aplicações da energia nuclear à sintetização de novos materiais e combustíveis baseados no hidrogênio, dessalinização da água do mar e muitas outras.

Ademais, a indústria nuclear amplificada e aprimorada deverá ser um dos setores de ponta para levar a economia mundial a níveis mais elevados de produtividade física e postos de trabalho qualificados, que possibilitem uma reversão dos enormes desequilíbrios e desigualdades fomentados pelas políticas econômico-financeiras das últimas décadas ${ }^{1}$.

O mundo presencia agora um grande renascimento da energia nuclear, desencadeado principalmente pelos altos níveis recentes de crescimento das economias físicas da China, Índia e alguns outros países do que se costumava chamar "terceiro mundo". Praticamente todas as grandes nações estão engajadas ou planejando engajar-se em programas de energia nuclear. A Rússia anunciou a intenção de construir 40 usinas nucleares nos próximos 25 anos; os Estados Unidos da América (EUA) estão reativando a sua indústria nuclear; a França anunciou uma nova ofensiva para aumentar as exportações de tecnologia nuclear; e a África do Sul está se preparando para produzir em massa o seu projeto próprio de reator nuclear, o reator modular de alta temperatura, tanto para uso doméstico, como para exportação para países em desenvolvimento em todo o mundo. A lista poderia ser continuada. E, não menos importante, o Brasil está se comprometendo para com um futuro com energia nuclear ${ }^{2}$.

No governo do Presidente da República Luiz Inácio Lula da Silva, o Brasil recupera a percepção de que a excelência científico-tecnológica é o caminho mais interessante para um desenvolvimento sócioeconômico nacional sustentável. Nesse sentido, o incremento da área nuclear, por seu caráter multifacetado, é defendido como um dos vetores fundamentais para a viabilização desse projeto, tornando-se base para a realização do interesse nacional, qual seja, uma inserção externa soberana em que pesem a valorização e prestígio do país frente àqueles desenvolvidos e aos seus pares em desenvolvimento. 
Nesse contexto, a energia nuclear aparece também como alternativa, mas inspira cuidados no desenvolvimento tecnológico pela interface bélica e políticoestratégica que possui. Os pontos positivos dessa energia estão relacionados ao desenvolvimento de uma tecnologia de ponta, ao alcance de excelência que pode ser absorvida em outros setores da produção, ao incremento da indústria de defesa, ainda que para fins pacíficos e à possibilidade de diversificação da pauta de exportações, participando do restrito mercado de produtos do ciclo do combustível nuclear. Paralelamente, a energia nuclear traz como negatividade o alto custo e tempo para a construção de usinas, a pressão internacional nas áreas de defesa e comércio e a questão ambiental, pois, se de um lado, ao se adequar às exigências do Protocolo de Kioto sobre a redução na emissão de gases poluentes, por outro, produz rejeitos radioativos que requerem processos de tratamento específicos, problema não totalmente solucionado em todos os países que utilizam termonucleares ${ }^{3}$.

\subsection{Principais razões que levaram o autor a realizar a pesquisa}

A motivação para a escolha do tema está associada à necessidade da introdução, da segurança em um grau elevado de sofisticação e da harmonização nas atividades empreendidas pelo uso da energia nuclear e das radiações ionizantes com a utilização de uma legislação rígida. Com a finalidade de salvaguardar a saúde e o bem estar do indivíduo, impondo o paradigma de que o uso da energia nuclear e das radiações ionizantes produz um benefício máximo e um detrimento mínimo à saúde da população como um todo e dos indivíduos considerados singularmente. Trata-se da exposição de um estudo científico de tema único e bem delimitado, elaborado com base em investigação original, constituindo-se em real contribuição para a especialidade em questão.

\subsection{A importância do problema levantado}

\subsubsection{O problema da pesquisa}

A radioproteção ocupacional e ambiental praticada em nosso país está de acordo com os padrões internacionais de segurança radiológica e nuclear?

\subsubsection{Hipótese básica}

Tendo por base a hipótese de que a proteção e segurança das usinas e instalações nucleares, assim como das instalações radiativas, são fundamentais para que a área nuclear se consolide e tenha apoio da sociedade e da comunidade científica. Um incidente ou acidente em qualquer das instalações pode provocar um veto político à tecnologia por décadas, além do impacto indesejável na opinião pública mundial e no 
relacionamento entre as nações. Portanto, a preservação do meio ambiente e a proteção da população e dos trabalhadores dos efeitos indesejáveis da energia nuclear devem ser pressupostos fundamentais na organização das empresas e da pesquisa, seguindo os padrões e acordos internacionais, garantindo um desenvolvimento ao mesmo nível dos países detentores da tecnologia, como aos da União Europeia (UE).

Acordos internacionais na área nuclear, dos quais o Brasil participou da elaboração e é signatário, exigem que haja separação efetiva entre fiscalização/controle e pesquisa/desenvolvimento. Sendo assim, concluímos que mudanças na estrutura de regulação do setor nuclear brasileiro são necessárias, objetivando a criação de uma agência reguladora de atividades nucleares nacional, para que a radioproteção ocupacional e ambiental praticada em nosso país, embora exista e seja efetiva, venha estar de acordo com os padrões internacionais de segurança radiológica e nuclear.

A experiência internacional dos órgãos regulatórios nucleares e os erros e acertos na criação das agências regulatórias brasileiras representam um ponto de partida importante na formulação de uma legislação moderna para a criação de uma agência reguladora de atividades nucleares nacional. Com o objetivo de assegurar que o estado da arte e da tecnologia, em termos de segurança nuclear, seja à base do exercício de suas atividades normativas, de fiscalização e de avaliação de segurança. Assim como seja garantida a participação em suas decisões de todos os segmentos da sociedade envolvidos na preservação do meio ambiente, da saúde do público e dos trabalhadores, frente às aplicações da energia nuclear. A garantia de independência política de atuação da agência reguladora de atividades nucleares é um dos dispositivos jurídicos essenciais para que os interesses dos proprietários das instalações e da indústria nuclear não venham a interferir em suas decisões.

\subsection{Alcance da pesquisa e delimitação do assunto}

O tema estudado é original e contemporâneo, pois é objeto de análises e críticas, não só no âmbito nacional, mas também no internacional, diante do uso crescente de novas tecnologias no setor e a necessidade de uma regulamentação atual e de acordo com os padrões de segurança internacionais para assegurar a sua utilização. Com efeito, o processo de consolidação normativa na área nuclear brasileira exige um novo marco regulatório; o trabalho elaborado poderá desenvolver contribuição efetiva para esse debate e para as mudanças necessárias na área regulatória. A delimitação do assunto está estruturada por um recorte de pesquisa que investiga a atualização e a otimização da 
legislação brasileira na área de energia nuclear para seu uso pacífico e de acordo com os padrões internacionais de segurança e sustentabilidade. Assim sendo, o campo de observação da tese centrou-se e desenvolveu-se nesta área de estudo, um trabalho de investigação que representa contribuição original ao estado da arte do tema tratado para a construção do conhecimento e para a prática profissional.

\subsection{Relação do trabalho com outros similares}

O presente trabalho objetivou, partindo de uma revisão do arcabouço legal nuclear na legislação nacional, comparar o resultado com a legislação nuclear da UE, que atualmente congrega 27 países europeus democráticos e constitui sua base jurídica no Tratado Euratom, Tratado que fixa obrigações e competências desenvolvidas no domínio da energia nuclear, particularmente em matéria de investigação bem como do controle da segurança nuclear. As salvaguardas nucleares do Tratado Euratom, bem como sua legislação, se articulam com as garantias exercidas pela Agência Internacional da Energia Atômica (AIEA) e suas recomendações, no âmbito de acordos tripartidos concluídos pelos Estados-Membros, a Comunidade Europeia e a AIEA.

Com a comparação entre as legislações, foram contextualizados os pontos fortes e os pontos fracos entre ambas, com destaque para os aspectos de proteção e segurança e oferecidas sugestões para as mudanças que julgamos necessárias na legislação nacional. Pontos em destaque da originalidade do presente estudo.

Tomando como referencial essas considerações, o presente estudo não encontra similaridade com outros na literatura científica e está estruturado por meio de uma discussão subdividida em onze seções e um apêndice.

Por fim, considerações finais são tecidas à guisa de conclusão a partir de recuperação de algumas constatações desenvolvidas ao longo do texto, com o objetivo de sintetizar uma discussão final sobre a temática em questão. 


\section{FINALIDADE, OBJETIVOS E JUSTIFICATIVA}

\subsection{Finalidade}

Demonstrar se a radioproteção ocupacional e ambiental praticada em nosso país está de acordo com os padrões internacionais de segurança radiológica e nuclear.

\subsection{Objetivos}

- Atualizar e revisar a legislação brasileira no setor de energia nuclear, comparando-a com as da UE.

- Contextualizar os pontos fortes e os pontos fracos da legislação nacional a partir da comparação.

- Apontar a importância da adoção de ações corretivas, fundamentando-se o direito e sua aplicação.

- Contribuir com críticas e sugestões, para que haja uma maior e cuidadosa reflexão sobre a questão e, consequentemente, para que reformas sejam realizadas na legislação nacional vigente, visando a sua otimização e adequação aos padrões internacionais.

\subsection{Justificativa}

Há uma ampla gama de necessidades de aplicações nucleares nas áreas de energia, indústria, saúde, meio ambiente, agricultura e recursos hídricos que demandam continuamente novos e melhores produtos e serviços, que contribuem diretamente para a qualidade de vida da população. Para a utilização segura dessas aplicações, deve-se considerar a necessidade de assegurar a proteção do trabalhador, da população e do meio ambiente, a partir do aumento do número de instalações nucleares e radioativas no país e do conseqüente aumento da geração de rejeitos radioativos.

A atualização e revisão da legislação brasileira no setor da energia nuclear concernente às atividades nucleares no Brasil é um aspecto que deve ser aprimorada e constantemente acompanhada, até como meio que proporcione o fortalecimento da comunicação e interação da equipe gerencial e executiva.

Com o reaparecimento dos debates concernentes às mudanças climáticas, a tendência é de se enfatizar as atividades nucleares no setor de energia, visando à diversificação da matriz energética brasileira e a busca ao aceleramento das pesquisas em fusão nuclear. 
A expansão das atividades nucleares exige que os atores envolvidos continuem mantendo negociações para reformulação do Programa Nuclear Brasileiro (PNB) e para a melhoria do arcabouço institucional vigente.

Nesse cenário, a importância científica e social do problema, a atualidade do tema e a contribuição efetiva que se poderá realizar para a formulação de políticas públicas para o setor de energia nuclear, a opção pelo tema se justifica, e a sua relevância, para o autor.

Neste contexto, o tema do presente trabalho é realmente significante, apresentando contribuição original à área do conhecimento. 


\section{METODOLOGIA}

A presente pesquisa classifica-se quanto aos fins em exploratória e quanto aos meios em bibliográfica e documental.

$\mathrm{Na}$ elaboração da pesquisa bibliográfica e documental foram utilizadas bases de dados referenciais nacionais e internacionais de assuntos que estão publicados em livros, artigos de revistas, eventos e teses, a saber: INIS - International Nuclear Information System, Nuclear Power, IAEA Library Catalogue, Nuclear Fuel Cycle \& Waste Technology, Planning \& Economic Studies Section, Energy Technology Data Exchange, Scielo - Scientific Electronic Library Online, NDLTD -Networked Digital Library of Theses and Dissertation, Biblioteca digital brasileira de teses e dissertações, Biblioteca do Senado Federal, Bibliografia Brasileira de Direito, Biblioteca Digital de Teses e Dissertações da Universidade de São Paulo, Banco de teses da Coordenação de Aperfeiçoamento de Pessoal de Nível Superior e Biblioteca Digital de Teses e Dissertações da UNESP.

Também foram consultados livros e artigos com literatura especializada na área nuclear, dos últimos 10 anos, nos idiomas português e inglês. Para responder aos objetivos desse estudo, com relação à legislação nacional, o corpo teórico utilizado centrou-se inicialmente em um histórico da energia nuclear em nosso país, em seguida foi efetuada uma análise da Constituição da República Federativa do Brasil (CF) e de um consolidado da legislação brasileira aplicada ao setor nuclear, uma seleção de textos legislativos inerentes à área, elaborada e organizada pelo autor em quatro partes. A saber: Decreto, Decreto-Lei, Decreto Legislativo e Lei. Cada parte iniciando-se por uma relação histórica da legislação com os respectivos objetos explicitados que se encontram em vigor ou são referenciados na atual legislação. Essa bibliografia encontra-se no apêndice deste trabalho.

Esse trabalho bibliográfico atualizado até dezembro de 2007, ampliado até a presente data e completado com os textos, na íntegra, será posteriormente colocado no formato adequado para futura publicação a respeito de toda a legislação nacional em apreço.

Em seguida foi realizada uma pequena introdução à regulação internacional e nacional na área nuclear para adentrar-se posteriormente na legislação européia, onde foram selecionados e estudados os Tratados constitutivos da base da UE, para compreensão da sua estrutura e funcionamento como um todo e com ênfase estudou-se o 
Tratado Euratom que abarca a energia nuclear na UE. Por fim foi discutido o panorama atual da energia nuclear na Europa.

O autor foi contemplado com uma bolsa de estudos do Programa de Mobilidade Internacional de Pós-Graduandos da Universidade de São Paulo (USP), que lhe permitiu a realização de um estágio na Universidad de Sevilla, na Espanha, por um período de seis meses onde, além de realizar pesquisas nas bibliotecas da Universidade, participou do Curso de Extensão Universitária, denominado Tratado de Lisboa: Novedades en el proceso de construcción comunitária, que discorre sobre a legislação, a política do meio ambiente e desenvolvimento sustentável na UE. Curso esse promovido pelo Centro de Documentação Européia da Universidad de Sevilla, realizado pela Faculdade de Direito da referida Universidade.

Participou também, de visitas monitoradas às Casas Legislativas do Brasil (Câmara dos Deputados e Senado Federal) e da UE (Conselho e Comissão Europeia). Durante a realização do estágio e das visitas, foi observado na teoria e na prática, o desenvolvimento das leis, que formam a base jurídica da legislação nacional e européia, com ênfase na área nuclear. Para o desenvolvimento de toda essa parte referente à energia nuclear na EU, essas participações foram de grande utilidade.

Com a bibliografia colocada no apêndice deste trabalho acredita-se ter cumprido o primeiro objetivo.

Entenda-se ser original o conteúdo do apêndice, ainda que seja uma mera compilação de Decretos, Decretos-Lei, Decretos Legislativos e Leis nacionais a respeito da energia nuclear, pela colocação do autor.

As idéias expostas no presente trabalho são todas originais, uma vez que representam a visão e o conhecimento adquirido pelo autor, no sentido de implantar uma política nuclear nacionalista que permita ao país entrar na competitividade internacional e formar uma indústria nuclear nacional, utilizando-se dos meios mais modernos de proteção, segurança e seguridade.

De posse de todo o arcabouço técnico-científico e legislativo nacional e internacional, partiu-se para cumprir os demais objetivos. 


\section{A HISTÓRIA DA ENERGIA NUCLEAR NO BRASIL}

\subsection{Primórdios da energia nuclear no Brasil}

A história da energia nuclear no Brasil inicia-se no pós-guerra com a luta do Almirante Álvaro Alberto da Motta Silva contra as "pressões" americanas para alcançar o controle de propriedade das reservas mundiais de Tório e Urânio. O Almirante Álvaro Alberto, representante brasileiro na Comissão de Energia Atômica (CEA), do Conselho de Segurança da Organização das Nações Unidas (ONU), no qual teve por duas vezes assento, (1946-1947), se insurgiu contra a administração e domínio das jazidas de minerais nucleares estratégicos, por organização a ser criada pela CEA, proposta pelo representante norte-americano Bernard Baruch, mundialmente conhecida como Plano Baruch. A proposta visava a criação de uma autoridade internacional de controle de energia atômica que deveria assumir a posse e a administração de todos os respectivos meios de produção, controlando as reservas de minerais radioativos, ao redor do mundo, propondo que todos os países, com reservas de minerais nucleares, colocassem os seus suprimentos sob a sua responsabilidade. O objetivo era não permitir que os países tivessem acesso a materiais ou equipamentos com que fosse possível construir armas nucleares, devendo todos ficar na posse e sob controle dessa autoridade ${ }^{4}$.

Em 1951, o Presidente da República Getúlio Vargas criou o Conselho Nacional de Pesquisas (CNPQ) nomeando o Almirante Álvaro Alberto para presidi-lo.

No mesmo ano, o Almirante Álvaro Alberto propôs uma legislação que protegesse as reservas nacionais de Tório e Urânio contra a espoliação estrangeira. Nesse contexto, o Almirante defendeu a tese das compensações específicas, o que valia dizer que nenhuma transação comercial com minerais estratégicos deveria se realizar contra pagamento em dólares, mas sim em base de troca de tecnologia.

As resistências do Almirante Álvaro Alberto foram insuficientes para impedir o "arrebatamento" das jazidas brasileiras pelos norte-americanos que, já em 1952, importavam de uma só vez toda a cota de Tório que lhes foram garantidas para dois anos de acordo.

A inflexibilidade dos norte-americanos "comprometidos" pela força do Mcmahon-Act inviabilizava qualquer cooperação com o Brasil. A pretendida cooperação, entretanto, era uma ilusão do enviado americano para "nutrir" a política de exportação de minerais que Gordon Dean, Presidente da Comissão de Energia Atômica dos Estados Unidos da América (CEAEUA) de 1950 a 1953, insistia em “fomentar". Em virtude, disso 
o Almirante Álvaro Alberto pediu autorização ao governo brasileiro para encetar negociações com outros países. Em missão do CNPQ, ele viajou para a Europa onde faria contato na França e na Alemanha ocupada pelos aliados.

Na França, negociou a aquisição de uma usina de yellow cake e, na Alemanha propôs que os cientistas alemães, em atividade à margem da legalidade aliada, fornecessem ao Brasil a tecnologia de enriquecimento de Urânio rejeitada pelos americanos.

Nesse ponto a missão do Almirante Álvaro Alberto assumia forma de missão secreta, na medida em que suas ações passavam a ignorar outras instâncias decisórias, como o Conselho de Segurança Nacional (CSN), o Departamento Nacional de Produção Mineral (DNPM) e o Estado Maior das Forças Armadas (EMFA), pois, para completar sua tarefa, isto é, transferir os protótipos das centrífugas de Urânio para o Brasil, ele dependia de uma diplomacia secreta à margem do Ministério das Relações Exteriores do Brasil. A embaixada brasileira em Bonn recomendou que se aguardasse o estabelecimento da plena soberania da Alemanha Ocidental, quando então seria possível a importação das centrífugas.

Formalmente o CNPQ aceitou a recomendação, mas o Almirante Álvaro Alberto solicitou ao então Presidente da República Getúlio Vargas, uma autorização especial no sentido de que o Ministério das Relações Exteriores apoiasse o embarque secreto das máquinas.

As centrífugas foram apreendidas em Göttingen e Hamburgo pelo Conselho Militar de Segurança, menos de 24 horas após essa consulta. O plano do golpe feito contra a encomenda fora forjado pela CEAEUA. O Almirante Álvaro Alberto, ao contatar o presidente dessa Comissão Lewis Strauss, presidente de 1953 a 1958, não recebeu desse, nenhuma esperança de que os aparelhos apreendidos pelos aliados fossem liberados. Por outro lado Strauss, habilmente, contra-atacaria com uma oferta de "ajuda" dos EUA, nos moldes permitidos pela política nuclear americana. O Almirante Álvaro Alberto, mais uma vez, repetiria os desejos de seu governo: usinas de enriquecimento, uma fábrica de produção de hexafluoreto de Urânio, além de reatores de pesquisa.

A rejeição da CEAEUA fez o Almirante voltar de mãos vazias e a providência seguinte foi sua exoneração do CNPQ, em março de 1955. Logo em seguida, em agosto do mesmo ano, é assinado com os EUA o Programa de cooperação para o reconhecimento dos recursos de Urânio no Brasil. Em meados de 1956 é instalada uma Comissão parlamentar de inquérito (CPI) para investigar o problema da energia atômica no país, devido à aceitação das condições de negociação com os EUA levando à mudança da política 
brasileira na exportação de minerais estratégicos, como também a possível relação da exoneração do Almirante Álvaro Alberto ter sido motivada por "pressões" norteamericanas, explicitadas em quatro documentos secretos, oriundos da diplomacia americana $^{5}$.

\subsection{Uma política nuclear nacional}

A CPI recomendou a revisão de acordos internacionais que prejudicavam o país, e o Governo, então, nomeou uma comissão interministerial, cujas diretrizes, aprovadas pelo CSN, estabeleciam que o ponto fundamental da política nuclear deveria ser produzir no país combustíveis nucleares sob total controle e propriedade do Governo.

A Comissão Nacional de Energia Nuclear (CNEN), desmembrada do CNPQ em 1956 para executar a política nuclear já citada, estabeleceu estreita colaboração com os EUA, através de acordo de cooperação nuclear dentro do Programa Átomos para a Paz.

Nessa fase perderam-se iniciativas promissoras, como o Grupo do Tório, grupo esse do Instituto de Pesquisas Radioativas de Belo Horizonte, que conseguiu, entre 1955 e 1960, desenvolver um projeto de um reator alimentado a Tório. No entanto, findo o trabalho, o grupo foi dissolvido. Segundo o relatório final do Grupo do Tório, foi desenvolvido o projeto preliminar de referência de um reator, cuja tecnologia ligada ao projeto, poderia ser desenvolvida no Brasil, que não era tão complexa, já que tudo indicava que o mais apropriado para o país era a opção Urânio natural, seguida da opção PlutônioTório para o prazo mais longo 5 .

\subsection{Primeira usina nuclear brasileira}

O Governo brasileiro, ainda sob forte influência dos acordos de 1955 com os norte-americanos, assumiu uma decisão, precedida de estudos preliminares detalhados; esse estudo oficial definiu uma conceituação básica para o projeto da central nuclear da região sudeste do Brasil. Segundo este estudo a central nuclear deveria ter como finalidades principais:

- Demonstrar a viabilidade técnica e econômica da energia produzir material físsil para o futuro;

- Iniciar a implantação de uma indústria nuclear no país.

Em 1968, entre as opções de reatores a água leve (EUA), a gás grafite (França e Inglaterra) e água pesada (Canadá e Suécia), foi escolhida a opção Urânio enriquecido, sob a razão principal de adoção do tipo de reator comprovado tecnicamente, a vista do vulto dos investimentos e da importância da central como fonte confiável do suprimento do sistema elétrico brasileiro. 
Em julho de 1972, o Brasil assinava um contrato com a empresa Westinghouse, dos EUA, que assumiu o compromisso de construir a primeira usina nuclear de potência no Brasil.

Nesse contrato, a "dependência” dos EUA era ampla, não deixando muita liberdade para o crescimento da tecnologia nuclear no país. Dessa forma, era previsto o fornecimento de $500 \mathrm{t}$ de Urânio enriquecido para ser utilizado no reator, no prazo de 30 anos e o governo dos EUA teria direitos, tais como: examinar o projeto de qualquer reator; examinar outros equipamentos e artefatos cujo projeto tivesse, ao juízo da Comissão regulatória americana, relevância para aplicação de salvaguardas nucleares.

Além dessas graves disposições unilaterais, os EUA se asseguravam, ainda, do direito de designar o pessoal que teria acesso no Brasil a todas as instalações e a todos os dados necessários para o inventário de material fértil e do material nuclear.

O país não poderia alcançar assim, evidentemente, nenhum desenvolvimento no setor nuclear com tal "subordinação" política".

\subsection{Implantação de centrais nucleares}

Nos anos de 1973 e 1974 a CNEN, através de sua subsidiária, a Companhia Brasileira de Tecnologia Nuclear (CBTN), criada em 1971, realizou estudos de viabilidade referentes à introdução da tecnologia nuclear em larga escala no país. Como resultado desses estudos foi estabelecida uma estratégia de implantação de centrais nucleares que resultou na criação da Empresas Nucleares Brasileiras (NUCLEBRAS), oriunda da CBTN e que seria a empresa majoritária encarregada de implantar no país uma indústria pesada para a fabricação de reatores e uma indústria abrangendo todas as etapas do chamado ciclo do combustível nuclear, para proporcionar uma capacidade nuclear de eletricidade.

A estratégia definida nos estudos da CBTN, e adotada pela nova empresa majoritária do setor, optou pelo modelo de transferência de tecnologia, sendo interessante frisar que Angra 1 foi um empreendimento fora dessa estratégia de implantação de tecnologia nuclear e transferência de tecnologia, tendo sido um empreendimento turn-key.

A partir desse ponto as negociações que vieram a se concretizar, em 1975, na assinatura do acordo com a República Federal da Alemanha (RFA), foram feitas no maior sigilo, para evitar-se as experiências anteriores em que interferências externas à soberania nacional impediram o desenvolvimento nesse setor ${ }^{5}$.

\subsection{Rompimento das negociações com os americanos}

As "pressões" dos norte-americanos prosseguiram através do Senado dos EUA e até mesmo durante a campanha presidencial do candidato Jimmy Carter. 
O Brasil havia rompido negociações com os EUA meses antes do acordo com a Alemanha, em razão das empresas americanas não poderem legalmente realizar as seguintes transações:

- Produção/participação de material nuclear fora dos EUA;

- Construção de instalação para o processamento de elementos irradiados ou para a produção de água pesada;

- Construção de instalação ou fornecimento de peças para a separação isotópica;

- Prestar auxílio aos estrangeiros na compra, projeto ou instalações para o enriquecimento de Urânio e processamento de material irradiado.

No início de 1977, o Governo Carter ameaçou colocar em prática um programa de estágios repressivos, caso os parceiros do acordo não aceitassem condições americanas constituídas do seguinte elenco de possíveis propostas, algumas mutuamente exclusivas:

- Participação americana no acordo e no processo de transferência de tecnologia do enriquecimento e reprocessamento de Urânio;

- Usina de reprocessamento construída num país neutro, do continente latino americano, e submetida ao controle internacional. Em sendo a usina construída no Brasil, teria que ser submetida aos controles complementares do sistema da Agência Internacional de Energia Atômica (AIEA);

- Propunham a formação de um cartel internacional de empresas construtoras e vendedoras de tecnologia nuclear, proporcionando uma margem de lucro ao setor, de forma que pudesse dispensar os acordos de exportação dessa tecnologia aos países em desenvolvimento ${ }^{5}$.

O programa de represálias constituía-se de:

- Levantar pesadas barreiras alfandegárias contra produtos alemães e brasileiros no mercado interno americano;

- Bloquear a exportação de produtos dos quais havia dependência no Brasil e na Alemanha;

- Bloquear o acesso do Brasil aos mercados financeiros;

- Embargar o fornecimento de Urânio enriquecido e em forma natural que já tinha sido contratado com a Alemanha;

- Demagogicamente ameaçar a retirada das "tropas" de proteção norteamericanas sediadas em solo alemão. 


\subsection{Acordo Brasil - Alemanha}

As diplomacias brasileira e alemã resistiram às "pressões" dos EUA e, através da NUCLEBRAS, o Acordo Brasil-Alemanha para implantação de tecnologia nuclear no Brasil, foi iniciado.

$\mathrm{O}$ artigo primeiro do acordo diz que o Brasil e a RFA fomentarão a cooperação entre instituições de pesquisa científica e tecnológica e entre empresas dos dois países, abrangendo o seguinte:

- Prospecção e processamento de minerais de Urânio;

- Produção de compostos de Urânio;

- Produção de reatores nucleares e outras instalações nucleares bem como seus componentes;

- Enriquecimento de Urânio e serviços de enriquecimento;

- Produção de elementos combustíveis;

- Reprocessamento de combustíveis irradiados.

Essa cooperação implicava intercâmbio de informações tecnológicas, sendo o Brasil co-proprietário das mesmas. A partir do acordo foram criadas, como instrumento de implementação, as seguintes empresas binacionais:

- NUCLEP - NUCLEBRAS Equipamentos Pesados (75\% da NUCLEBRAS e $25 \%$ da KWU, GHH e VAL) com o fim de projetar, desenvolver, fabricar e vender componentes pesados de usinas nucleares e de outros projetos energéticos, instalada em Itaguaí-RJ.

- NUCLAM - NUCLEBRAS Auxiliar de Mineração (51\% da NUCLEBRAS e o restante da URANGESELLSCHAFT) destinada a realizar a prospecção, a pesquisa, o desenvolvimento e a exploração dos depósitos de Urânio e extrair, beneficiar, processar e tornar adequados ao comércio o Urânio natural e seus subprodutos.

- NUCLEN - NUCLEBRAS Engenharia S/A (75\% da NUCLEBRAS e 25\% da KRAFTWERKE UNION GESELLSCHAFT), com o fim de elaborar projetos de engenharia para usinas nucleares e projetos afins e habilitar a indústria brasileira a fabricar componentes para essas usinas.

- NUCLEI - NUCLEBRAS Enriquecimento Isotópico $\quad(75 \%$ da NUCLEBRAS e $15 \%$ da INTERATOM e $10 \%$ da STEAG), usina de enriquecimento a jato centrífugo em Resende-RJ. 
- NUSTEP (50\% da NUCLEBRAS e $50 \%$ da STEAG) para o desenvolvimento do processo jato centrífugo de enriquecimento.

$\mathrm{E}$ as nacionais:

- NUCLEMON - NUCLEBRAS Pesquisa de Tório e Areias Monazíticas S/A (100\% NUCLEBRAS) atuando fora da execução do acordo nas atividades de pesquisa, lavra, concentração e industrialização.

- NUCON - NUCLEBRAS Construtora de Centrais Nucleares S.A., criada em 23/10/1980 (100\% NUCLEBRAS) para a construção de centrais nucleares.

As dificuldades financeiras impostas ao Brasil concorreram, a partir de 1983, para reduzir a regularidade, principalmente das usinas nucleares de Angra 2 e Angra 3. As usinas 4 e 5, previstas inicialmente no acordo e cujos sítios chegaram a ser definidos tiveram seus cronogramas congelados em 1983 e a concorrência para entrada da contratada para a construção civil, cancelada.

Iríamos iniciar um período abrangendo três Presidentes da República onde, a indecisão do Governo, na tomada de uma decisão política deixaria o Programa Nuclear Brasileiro (PNB), especificamente, no que concerne à construção de usinas nucleares, praticamente estacionada por longos 13 anos.

De lá para cá ocorreram muitas mudanças institucionais, algumas frutos do casuísmo típico da política brasileira, outras necessárias para correção de rumos e busca de equações financeiras que permitissem dar continuidade ao que restava do $\mathrm{PNB}^{5}$.

\subsection{Avaliação do PNB pós-governos militares}

Com o início da chamada "nova república" e o fim do ciclo de Governos militares, em 1985 houve a criação de uma Comissão de alto nível para avaliação do PNB, cujo relatório final, em 1986, apresentou as seguintes e principais conclusões gerais:

- As aplicações pacíficas da energia nuclear assumem importante e crescente papel no desenvolvimento social e econômico dos povos e vem promovendo profundas alterações na distribuição de poder entre as nações. Entre as aplicações do domínio do núcleo atômico, avulta, pela escala de produção, complexidade e volume de recursos envolvidos em seu desenvolvimento, a implementação da geração nucleoelétrica que, mundialmente, já apresenta $18 \%$ da geração de eletricidade;

- A tecnologia nuclear faz apelo aos mais diversos setores industriais de ponta, exigindo níveis de qualidade e segurança tais, que seu domínio propicia grandes benefícios à sociedade como um todo. Ela não só participa cada vez mais da geração de 
energia elétrica, como promove a melhoria de qualidade de vida do homem através de suas múltiplas aplicações à medicina, agricultura e indústria;

- O Brasil deverá atender suas necessidades energéticas futuras pelo uso cada vez mais intenso de fontes térmicas, notadamente do carvão e da energia nuclear, face ao esgotamento previsível de seu potencial hidroelétrico. Adotando-se projeções de demanda de energia elétrica mais conservadoras e os custos de geração eletronuclear mais elevados, o potencial hidroelétrico estará esgotado no ano 2016 necessitando-se, a partir desta data, de um mínimo de $3.000 \mathrm{MW} /$ ano de origem térmica para o atendimento do mercado;

- A auto-suficiência nacional no setor energético e o uso eficiente de formas pioneiras de geração de energia, hoje em desenvolvimento serão alcançados mediante a implantação de intenso e coordenado trabalho de pesquisas científicas e tecnológicas, de pesquisas aplicadas e das empresas. A natureza multidisciplinar e o caráter universal do uso da energia exigem a mais forte interação de setores, que transcende o campo energético, tal como ordinariamente compreendido. No caso da energia nuclear, este esforço deve ser dirigido não só para a apropriação, adaptação e nacionalização da tecnologia disponível através dos programas estabelecidos de cooperação internacional, mas também para aquelas vias de desenvolvimento que se revelam promissoras para levar o país no mais breve período, à independência tecnológica no setor;

- A retomada do PNB a um nível de atividades compatível com a complexidade técnico-científica, industrial e de segurança própria do setor nuclear demanda um esquema financeiro capaz de dar-lhe sustentação por períodos de tempo suficientemente longos para assegurar o seu êxito.

A Comissão de avaliação do PNB submete ao Presidente da República José Sarney de Araújo Costa as seguintes principais recomendações:

- Manter o PNB em face da importância estratégica que o domínio pleno e autônomo da tecnologia nuclear deverá desempenhar no atendimento da demanda de energia elétrica e na ampliação de benefícios múltiplos, à medicina, à agricultura e à indústria nacional;

- O ritmo de desenvolvimento do programa deverá basear-se em um equilíbrio cuidadoso entre as necessidades de suprimento energético, os custos da energia proveniente das várias fontes alternativas e o domínio imperativo da tecnologia nuclear, indispensáveis ao fornecimento da energia de que necessitará o país a médio e longo prazo; 
- Manter as relações de cooperações sobre os usos pacíficos da energia nuclear com a RFA, inclusive quanto as suas aplicações financeiras, levando em conta as modificações decorrentes do novo ritmo de implementação e da estrutura que venha a se adotar para o PNB;

- À vista do adiantado estágio de avanço dos programas nacionais de aplicações pacíficas da energia nuclear no Brasil e da Argentina, que são largamente equivalentes, buscar intensificar a cooperação nuclear bilateral visando, a promoção de empreendimentos conjuntos no campo dos usos pacíficos da energia nuclear, bem como o estabelecimento gradual de um mecanismo de inspeção mútua, de tais atividades, nos dois países.

Quanto ao programa de construções de centrais de equipamentos pesados e a implantação do ciclo do combustivel nuclear:

- Continuar os trabalhos de construção das usinas de Angra 2 e Angra 3, obedecidos aos cronogramas previstos para os seus términos (1992 e 1995), de modo a garantir o suprimento da demanda prevista tanto no Balanço Energético Nacional como no Plano de Recuperação do Setor de Energia Elétrica (1984);

- Manter as atividades de fabricação de componentes pesados em um ritmo compatível com as necessidades das centrais em construção. Paralelamente, mediante um acordo com o setor privado e revisto do protocolo NUCLEBRAS/ABDIB, devem ser buscados mercados complementares para os componentes referidos, tanto no país como no exterior;

- Prosseguir a implantação do ciclo de combustível nuclear adequando-o à demanda provável da geração nucleoelétrica e promovendo sua nacionalização progressiva.

Apesar das conclusões e recomendações do relatório da Comissão conhecido como Comissão Vargas (nome do cientista que comandou os trabalhos) os anos de 1986 e 1987 se passaram sem que medidas concretas com relação aos recursos do Tesouro Nacional fossem tomadas para operacionalizar as recomendações de retomada de ritmo na construção das centrais de Angra 2 e Angra 3. Os esforços entre a NUCLEBRAS e a ELETROBRAS foram somados, mas nada foi conseguido de efetivo na ocasião ${ }^{5}$.

\subsection{Programa Nuclear Autônomo}

No início da década de 80, o programa autônomo da Marinha, sob a direção do Almirante Othon Luiz Pinheiro da Silva, começou a concretizar-se sobretudo, depois de se 
verificar que a pretensa transferência de tecnologia de enriquecimento de Urânio através do processo de jato centrífugo que seria absorvida pela NUCLEBRAS, se mostrava inviável.

Durante esta década o programa nuclear civil é retirado de prioridade enquanto se intensificam as pesquisas paralelas em busca do domínio do ciclo do combustível nuclear.

Das experiências dessa década, destaca-se a implantação do Centro Experimental de Aramar (CEA) sob a área de influência da Marinha que, com farta alocação de recursos financeiros, logrou grande desenvolvimento.

Em quatro de setembro de 1987, o Presidente da República José Sarney de Araújo Costa anunciou, de forma suntuosa, o domínio da tecnologia do enriquecimento de Urânio pelo processo de ultra centrifugação dentro de um programa coordenado pela CNEN, executado no CEA e com a participação do Instituto de Pesquisas Energéticas e Nucleares (IPEN).

Esse programa contando com a participação também dos militares, principalmente a Marinha foi corriqueiramente conhecido no país, até 1988, como Programa Nuclear Paralelo (PNP), para diferenciá-lo do Programa Oficial da NUCLEBRAS. Embora, como ambos eram suportados pelo Governo, ambos teriam que ser considerados oficiais.

Mais tarde, a Marinha resolveu denominá-lo de Programa Nuclear Autônomo (PNA).

O esforço da Marinha estava e continua até hoje orientado para a futura construção no país de reatores para equipar submarinos ${ }^{5}$.

\subsection{Viabilização econômica das usinas Angra 2 e Angra 3}

Em 16 de maio de 1988, a portaria interministerial n. ${ }^{\circ}$ 48, da Secretaria Geral do Conselho de Segurança Nacional, criou um Grupo de trabalho interministerial (GTI) com finalidade de propor medidas para a viabilização econômica da conclusão de Angra 2 e Angra 3.

Nesse grupo, todas as partes envolvidas foram incluídas o que não acontecera antes com a Comissão Vargas, onde não havia participação de membros do Ministério da Fazenda (MF) e Secretaria do Planejamento e Coordenação Geral (SEPRAN).

Os estudos do GTI foram sumarizados na Exposição de Motivos Interministerial n. ${ }^{\circ} 7$ de 31/08/88 que apontava no seu item cinco os seguintes principais óbices decorrentes do modelo institucional vigente:

- Inviabilização da construção das usinas de Angra 2 e Angra 3; 
- Aumento do risco de racionamento de energia elétrica na região sudeste;

- Deterioração do relacionamento com a parte alemã;

- Dependência exclusiva da NUCLEBRAS de recursos do Tesouro Nacional;

- Dificuldades de participação da iniciativa privada nas atividades do setor nuclear;

- Sentimento de que o Governo sustenta dois programas independentes, um civil e outro militar;

- Descrédito da sociedade na energia nuclear.

Como conseqüência do trabalho do GTI, o Presidente da República José Sarney de Araújo Costa sancionou o Decreto-Lei 2464 de $31 / 08 / 88^{6}$ que modificava integralmente a estrutura do setor nuclear brasileiro.

As principais mudanças determinadas pelo Decreto-Lei foram:

- Extinção da NUCLEBRAS;

- Criação das Indústrias Nucleares Brasileiras (INB);

- Transferências do controle de todas as atividades do antigo Grupo NUCLEBRAS para a CNEN, com exceção daquelas relativas à construção de Angra 2 e Angra 3;

- Transferência da NUCLEN para a ELETROBRAS;

- Dissolução da NUCLAM e NUCLEI;

- Inclusão da NUCLEP e NUCLEMON nos programas governamentais de privatização.

Assim foram extintas a NUCLEI, NUCLAN, NUCLEMON E NUSTEP.

A NUCLEBRAS foi transformada nas Indústrias Nucleares Brasileiras (INB), controlada pela CNEN, englobando as funções do ciclo do combustível nuclear desde a mineração, passando pelo enriquecimento e atingindo a fabricação do combustível nuclear. O ciclo do combustivel nuclear foi fortemente influenciado pelos militares através da Secretaria de Assuntos Estratégicos (SAE), por tornar efetivo um acordo entre a Marinha e a INB para industrialização do processo de enriquecimento isotópico por centrífugas.

A NUCLEP, também controlada pela CNEN, atua no setor de equipamentos pesados, com forte influência da Marinha na sua administração, que conta com seus recursos para a construção de cascos de submarinos.

A NUCLEN, transferida para a ELETROBRAS, veio em 1997 fundindo-se com o Departamento Nuclear de Furnas, que se cindiu de FURNAS, transformar-se na 
ELETRONUCLEAR, empresa projetista e operadora de centrais nucleares. A cisão da parte nuclear de FURNAS estava ligada à privatização do setor elétrico, que não poderia ser efetivada, de acordo com a $\mathrm{CF}^{9}$, tendo as atividades nucleares em seu bojo.

Ao analisarmos os objetivos explícitos do Decreto-Lei, vemos que apenas o óbice "d", do Decreto-Lei foi, em parte, removido. Em parte, pois a transferência das centrais para o setor elétrico não impediu a continuação das restrições orçamentárias que penalizavam estes projetos desde 1983.

Houve uma evidente resistência por parte do setor elétrico ao recebimento da herança nuclear, pois o Decreto-Lei foi promulgado à revelia do setor que não queria aceitar os encargos financeiros adicionais decorrentes da absorção de Angra 2 e Angra 3.

Quanto aos objetivos secretos, foram alcançados, pois ao mesmo tempo em que se oficializava um programa militar, colocavam-se sob os cuidados da SAE, todas as atividades de pesquisa básica e industrial do setor nuclear.

Às vésperas da promulgação da $\mathrm{CF}^{9}$ de 1988 , que limitaria o desenvolvimento da atividade nuclear à prévia autorização do Congresso Nacional, a NUCLEBRAS é extinta e as até então atividades secretas oficializadas e trazidas ao conhecimento da sociedade brasileira através do Decreto-Lei $2464^{6}$.

Em maio de 1990 um novo grupo denominado GT-PRONEN foi formado, já então no governo do Presidente da República Fernando Affonso Collor de Mello, em uma clara demonstração de que o modelo estabelecido pelo Decreto-Lei $2464^{6}$ não atingiu os objetivos, permanecendo a falta de decisão política para equacionar de forma definitiva o setor nuclear.

Ao entramos, no governo do Presidente da República Fernando Henrique Cardoso, em 1994, completavam-se 19 anos desde a assinatura do acordo nuclear com a Alemanha e o país não possuía nenhuma usina dentro de seu escopo em operação comercial. Angra 2 ostentava o recorde mundial de usina nuclear com maior tempo de construção sem possuir, até aquela data, um cronograma estável de conclusão.

Talvez essa obscura referência e o argumento do risco de racionamento de energia elétrica na região sudeste, cada mês mais adquirindo força, fizeram com que, finalmente, o Governo brasileiro decidisse pela conclusão de Angra 2.

Em fins de 1994, meados de 1995, as equações financeiras e orçamentárias, elaboradas entre FURNAS e a ELETROBRAS permitiram autorizar a licitação pública para a contratação da montagem que vinha sendo frustrada desde 1982. 
Um cronograma com término previsto inicialmente para junho de 1999 foi acertado e, finalmente, em abril de 1996, foi assinado o contrato entre FURNAS e o Consórcio denominado UNAMON, formado por sete empresas de construção e montagem, para a montagem eletromecânica de Angra 2. O cronograma contratual foi sucessivamente reformulado para meados de 2000 e finalmente a usina iniciou sua pré-operação comercial em julho de 2000, embora sem ainda ter equacionado o contrato de suprimento de energia para FURNAS que não previa o faturamento da energia gerada por Angra 2, contemplando apenas a energia gerada por Angra $1^{5}$.

\subsection{Retomada do PNB e a conclusão de Angra 3}

Decorridos 33 anos da assinatura do Acordo Brasil-Alemanha pode-se dizer que o que resta desse acordo é a usina de Angra 2, que ficou pronta 25 anos após a assinatura do chamado "acordo do século", e Angra 3, ainda nas fundações.

O setor nuclear, na esteira das dificuldades da crise energética de 2001, conseguiu incluir, novamente na pauta energética, a discussão da retomada das obras de Angra 3, embora a construção dessa usina, que demandaria ainda cerca de cinco anos e meio para entrar em operação, não poderia ser apresentada como solução de curto prazo para os problemas de racionamento de energia elétrica.

Angra 3, levando-se em conta os equipamentos já adquiridos, é considerada pela ELETRONUCLEAR como estando com um progresso de 30\% na construção, mas não foi incluída nos relatórios mundiais da AIEA de 2002 (dados até dezembro de 2001), como usina "em construção", talvez devido à indefinição quanto à retomada das obras.

Após a apresentação ao Comitê Técnico $\mathrm{n}^{\mathrm{0}} 2$ do Conselho Nacional de Política Energética (CNPE), em cinco de dezembro de 2001, foram aprovados os estudos preliminares para a conclusão da obra da usina nuclear de Angra 3, iniciada em 1983, paralisada após três anos e na qual foram consumidos US\$ 750 milhões, devendo ainda demandar cerca de outros US\$ 1.75 bilhões para entrada em operação dentro de cinco anos e meio, caso se consiga um cronograma sem restrições financeiras. $O$ custo da manutenção da obra parada era de US\$ 20 milhões por ano. Esta aprovação foi obtida após a quebra de resistências de membros do Governo, como o ex-diretor da Agência Nacional do Petróleo (ANP), David Zylberstajn, do ex-presidente da Petrobras, Henri Reichstul e finalmente o ex-ministro do Meio Ambiente, Sarney Filho, que acabou através do Conselho Nacional de Meio Ambiente aprovando o projeto e selando a questão no Governo do Presidente da República Fernando Henrique Cardoso. 
Com a eleição de um novo Governo, com uma política energética divergente da política do Governo anterior, essa aprovação não foi suficiente para determinar-se uma data para o reinício das obras, até mesmo porque a aprovação, no âmbito do Governo do Presidente da República Fernando Henrique Cardoso, dependia de aprovações complementares dos Ministérios da Fazenda (MF), Planejamento, Orçamento e Gestão (MPOG), Minas e Energia (MME) e Meio Ambiente (MMA).

No ano de 2003 esperava-se selar, definitivamente, o destino das obras de Angra 3. A partir daquele ano, se ela fosse construída, já arrebataria de Angra 2 o título mundial de usina nuclear com maior tempo em construção.

O debate ainda não teria chegado ao fim. Luiz Pinguelli Rosa, então presidente da ELETROBRAS, afirmou no dia 19/09/2003 que, na nova matriz energética, não tinha absoluta convicção de qual seria a posição de Angra 3 e propôs que a iniciativa privada viabilizasse tal usina, com participação da estatal na gestão. Segundo explicou ${ }^{5}$ :

"A idéia é fazer uma empresa que teria um contrato com ELETRONUCLEAR para que toda a energia de Angra 3 fosse dessa empresa e comercializada por ela. Seria uma empresa comercializadora, mas não como as existentes aí. Ela seria criada para viabilizar o investimento e teria a garantia de que por 20 anos, ou pelo tempo acordado, toda a energia produzida seria dela. A empresa ganharia vendendo energia!".

Pinguelli Rosa disse não saber se a proposta era factível, devido às complicações contratuais, pois os custos de transações disso é que poderiam ser impeditivos, mas há exemplos anteriores, como no caso de Serra da Mesa, que inspiraram essa possibilidade.

A idéia se baseava na possibilidade de que a FRAMATONE, empresa francesa que adquiriu o capital da SIEMENS, investi-se os US\$ 1.8 bilhões necessários à conclusão de Angra 3.

As Comissões de Defesa do Consumidor, Meio Ambiente e Minorias e de Ciência e Tecnologia, Comunicação e Informática da Câmara dos Deputados realizaram audiência pública no dia 24/09/2003 para debater a política nuclear brasileira. O encontro atendeu a requerimentos aprovados nas Comissões de autoria dos deputados Ronaldo Vasconcellos (PTB-MG), Edson Duarte (PV-BA), Sarney Filho (PV-MA), Fernando Ferro (PT-PE), João Pizzolati (PP-SC) e Renato Cozzolino (PSC-RJ).

O objetivo foi discutir a retomada do PNB e a construção de Angra 3, comparecendo representantes dos MCT, MMA, MME, da ELETROBRAS, da 
ELETRONUCLEAR, da CNEN, da Sociedade Brasileira para o Progresso da Ciência (SBPC), além de organizações não-governamentais ambientalistas e sindicalistas. As primeiras informações publicadas na página eletrônica da ELETRONUCLEAR indicaram que esse foi um movimento de um grupo de "pressão" pró-Angra 3.

Esse grupo bastante ativo, programou em seguida um novo evento, o Seminário em Brasília Tecnologia Nuclear - Soberania e Desenvolvimento, realizado nos dias 30/09/03 e 1/10/03, com o objetivo de despertar a atenção das autoridades e da sociedade para a necessidade de dar prosseguimento ao PNB. Organizado pelas Comissões de Relações Exteriores, de Defesa Nacional, de Minas e Energia, de Ciência e Tecnologia e Comunicação e Informática, o encontro reuniu conferencistas que discutiram a importância da continuidade do PNB. Entre os temas, encontravam-se o Impacto dos Programas Nucleares no Mundo e o Impacto da Energia Nuclear na Indústria, na Medicina e na Agricultura. Finalmente, 2003 ainda não foi o ano da decisão tão defendida pelo setor nuclear 5 .

Em 2007, o CNPE, órgão de assessoramento do Presidente da República para a formulação e diretrizes de políticas públicas para o setor de energia, aprovou a conclusão da usina termonuclear Angra 3 e o início dos estudos de localização de uma quarta usina, indicando uma retomada do PNB. Estudos da Empresa de Pesquisas Energéticas (EPE) do MME, apresentam a necessidade de construção de quatro a oito usinas nucleares até 2030. Nesse contexto, no âmbito do MCT, foi iniciada a ampliação das ações relacionadas à viabilização do PNB, incluindo o fortalecimento institucional da CNEN, responsável pelas pesquisas e regulação do setor, e ainda, ações voltadas à capacitação da NUCLEP, para a fabricação de componentes destinados às novas usinas nucleares.

Com relação ao ciclo do combustivel nuclear, foram ampliados os investimentos para a finalização da primeira fase da planta de enriquecimento de Urânio da INB, instalação da planta-piloto de produção de hexafluoreto de Urânio por conversão gasosa, no CEA e o aumento da produção de Urânio. Essas ações estão destacadas no Plano de Ações 2007-2010 de Ciência, Tecnologia e Inovação para o Desenvolvimento (PACTI), em que o Programa Nacional de Atividades Nucleares (PNAN) é considerado estratégico.

Ainda na INB, em sua Unidade de Enriquecimento de Urânio, foram em 2007 concluídas as obras de infraestrutura relativas ao Módulo I, que compreende as cascatas de ultra centrífugas $1,2,3$ e 4 . Tais iniciativas fazem parte da estratégia para criar a capacidade industrial de suprir as futuras expansões da geração núcleoelétrica com um 
produto de alto valor agregado, além de dotar o país de autonomia tecnológica e industrial no fornecimento de combustível para as usinas nucleares Angra 1 e 2.

Em 2008, no Centro de Desenvolvimento da Tecnologia Nuclear (CDTN), em Belo Horizonte (MG), foram concluídas as instalações da nova unidade produtora de radioisótopos de meia-vida curta, que permitirá a ampliação da produção de radioisótopos e radiofármacos para diagnóstico e terapia de várias doenças. 


\section{ORDENAMENTO JURÍDICO E INSTITUCIONAL NACIONAL}

\subsection{Ordenamento jurídico}

O campo nuclear trabalha com fontes de radiação ionizante e estas, em qualquer quantidade, por menor que seja, são consideradas nocivas à saúde. Em virtude disso, a proteção e a segurança tanto da fonte de radiação, do meio ambiente e dos indivíduos torna-se de suma importância. Por causa disso a legislação do desenvolvimento das tecnologias nucleares está intimamente vinculada à legislação de proteção e segurança. Atualmente o campo de tecnologia nuclear abrange o intervalo de conhecimentos científicos e técnicos e, portanto, emprega profissionais em todos os campos do conhecimento, entre eles profissionais em Direito.

A proteção e a segurança são realizadas por meios físicos e outros, mas em seu nível inferior dentro da legislação nacional necessita de regulamentos. Geralmente realizados por profissionais técnicos pouco ou praticamente nada versados na parte legislativa e nestes casos cometem absurdos. Como este trabalho situa-se completamente no campo legislativo da tecnologia nuclear, mas é de fundamental interesse em ambos os campos, legislativo e técnico, esta subseção foi introduzida para esclarecimento dos conhecimentos técnicos atinentes ao campo normativo da legislação no desenvolvimento da tecnologia?.

\subsection{Processo legislativo}

As normas que compõem o ordenamento jurídico brasileiro encontram-se dispostas hierarquicamente e em forma piramidal, estando a $\mathrm{CF}^{9}$ no ápice dessa pirâmide legal, subordinando todas as demais. A subordinação jurídica implica em que uma determinada norma prevaleça sobre a inferior em casos de conflito. A norma hierarquicamente superior obriga a obediência da subordinada, de maneira que esta lhe deverá dar sempre inteiro cumprimento sob pena de vir a ser viciada ${ }^{8}$.

A $\mathrm{CF}^{9}$, no seu artigo 59, estabelece o processo legislativo brasileiro de forma hierárquica, compreendendo:

$$
\begin{aligned}
& \text { I - Emendas à Constituição; } \\
& \text { II - Leis complementares; } \\
& \text { III - Leis ordinárias; } \\
& \text { IV - Leis delegadas; } \\
& \text { V - Medidas provisórias; } \\
& \text { VI - Decretos legislativos; }
\end{aligned}
$$


VII - Resoluções.

Estes atos, pela sua importância, abrangem normas gerais e abstratas que são editadas com a participação do Poder Legislativo.

O Poder Executivo participa do respectivo processo de elaboração legislativa em termos de iniciativa de projetos, de sanção e de veto. Atualmente, participa do processo legislativo - função atípica - pela elaboração de medidas provisórias que, contudo, deverão ser convertidas em lei 30 dias após a sua edição.

O Congresso Nacional participa do processo em termos de iniciativa própria de projetos ou de apuração dos apresentados pelo Poder Executivo; de sua discussão e aprovação, e, conforme a sua natureza, de remessa do projeto aprovado ao Presidente da República para a formalidade da sanção ou, se esta for negada através do veto, de apreciação deste, acolhê-lo ou rejeitá-lo.

Os atos editados tão-só pelo Poder Executivo não fazem parte do processo legislativo.

Emendas constitucionais: são modificações ou alterações introduzidas no corpo da $\mathrm{CF}^{9}$, propostas ao Congresso Nacional que, no exercício do seu poder constituinte derivado da mesma $\mathrm{CF}^{9}$, as aprovará ou não seguindo um procedimento especial, totalmente original em relação ao processo legislativo comum.

A emenda aprovada é promulgada pelo próprio Congresso, independentemente da sanção do Presidente da República.

Leis complementares: são as que se destinam a desenvolver os princípios constitucionais que não sejam auto-aplicáveis, dependendo de regulamentação que elas consubstanciam.

Leis ordinárias: são as que versam matéria de natureza não constitucional. $\mathrm{O}$ seu processo de elaboração é o clássico, compreendendo a apresentação de um Projeto, passando pela discussão no Parlamento, indo à sanção do Presidente da República, e, finalmente, sendo publicada, quando adquire força impositiva geral.

Lei delegada: é aquela que, não sendo da competência privada de qualquer das casas do Congresso, pode ter a sua elaboração delegada do Presidente da República, a pedido deste.

Medidas provisórias: são atos legislativos com força de lei, de vigência temporária de trinta dias, postas excepcionalmente na esfera de competência privativa do 
Presidente da República, para enfrentar situação caracterizadamente de grande relevância social que esteja a reclamar solução urgente.

Decreto legislativo: está para o Congresso como o Decreto está para o Presidente da República. Em razão da matéria, mutatis mutandis, se equivalem, destinando-se o primeiro a legislar sobre a administração interna do Poder Legislativo; e o último, a regulamentar a ação do Poder Executivo no cumprimento das suas atribuições e das leis.

A diferença entre Decreto legislativo e Resolução, de que a seguir trataremos, está na sua tramitação, o primeiro obedecendo a todos os termos do processo legislativo ordinário, ao passo que o último segue um rito mais abreviado.

Resoluções: como os Decretos Legislativos, são atos de autoridade do Poder Legislativo não sujeitos nem subordinados à aprovação ou referendo do Poder Executivo.

Qualquer das duas Casas do Legislativo Federal, assim como o Congresso Nacional, pode aprovar resoluções próprias de sua competência exclusiva ${ }^{7}$.

\subsection{Atos administrativos}

Além das normas provenientes do Legislativo, existem outras no ordenamento jurídico nacional, que não integram o processo legislativo, mas encontram-se sob a nomenclatura de legislação, e são subordinadas àquelas.

Dentre estas, destacam-se os atos normativos e os atos ordinatórios.

- Atos normativos:

São os atos administrativos que contém um comando geral, sendo provenientes do Executivo. Como definido por Meirelles ${ }^{10}$ :

“[...] tais atos, conquanto normalmente estabeleçam regras gerais abstratas de conduta, não são Leis em sentido formal. São leis apenas em sentido material, vale dizer, provimentos executivos com conteúdo de lei, com matéria de lei, contudo proveniente de Poder outro que não o Legislativo. Esses atos, quanto gerais e abstratos, têm a mesma normatividade da lei e a ela se equiparam (não sofrendo controle judicial, somente quanto a sua constitucionalidade), mas, quando sob a aparência de norma, individualizam situações e impõem encargos específicos aos administrados, são considerados de efeitos concretos e podem ser atacados e invalidados direta e imediatamente por via judicial comum, ou por mandado de segurança, se lesivos de direito individual líquido e certo".

São eles:

"Decretos: são atos administrativos da competência exclusiva dos chefes do Executivo, destinados a prover situações gerais ou individuais. Comumente, o Decreto é normativo e geral, podendo ser específico ou individual. Como ato 
administrativo, o Decreto está sempre em situação inferior à da lei e, por isso mesmo, não a pode contrariar. O Decreto geral tem, entretanto, a mesma normatividade da lei, desde que não ultrapasse a alçada regulamentar de que dispõe o Executivo".

Segundo classifica Meirelles ${ }^{10}$, o "[...] ordenamento administrativo admite duas modalidades de Decreto geral (normativo): o independente ou autônomo e o regulamentar ou de execução.”, cujas definições dadas pelo mesmo autor encontram-se a seguir:

"Decreto independente ou autônomo: é o que dispõe sobre matéria ainda não regulada especificamente em lei. São admitidos somente para suprir a omissão do legislador, desde que não invadam as reservas da lei, isto é, as matérias que só por lei podem ser reguladas".

"Advirta-se, todavia, que os Decretos autônomos ou independentes não substituem definitivamente a lei: suprem, apenas, a sua ausência, naquilo que pode ser provido por ato do Executivo, até que a lei disponha a respeito. Promulgada a lei, fica superado o Decreto".

"Decreto regulamentar ou de execução: é o que visa a explicar a lei e facilitar sua execução, aclarando seus mandamentos e orientando sua aplicação. Tal Decreto comumente aprova, em texto à parte, o regulamento a que se refere. Questiona-se se esse Decreto continua em vigor quando a lei regulamentada é revogada e substituída por outra. Entendemos que sim, desde que a nova lei contenha a mesma matéria regulamentada".

"Regulamentos: Os Regulamentos são atos administrativos, postos em vigência por Decreto, para especificar os mandamentos da lei ou prover situações ainda não disciplinadas por lei. Desta conceituação ressaltam os caracteres marcantes do Regulamento: ato administrativo (e não legislativo): ato explicativo ou supletivo da lei; ato hierarquicamente inferior à lei; ato de eficácia externa".

“O Regulamento, embora não possa modificar a lei, tem a missão de explicá-la e de prover sobre minúcias não abrangidas pela norma geral editada pelo Legislativo".

"Como ato inferior à lei, o Regulamento não pode contrariá-la ou ir além do que ela permite".

"No que o Regulamento infringir ou extravasar da lei, é írrito e nulo, por caracterizar situação de ilegalidade. Quando o Regulamento visa a explicar a lei (regulamento de execução), terá que se cingir ao que a lei contém; quando se tratar de Regulamento destinado a prover situações não contempladas em lei (Regulamento autônomo ou independente), terá que se ater aos limites da competência do Executivo, não podendo, nunca, invadir as reservas da lei, isto é, suprir a lei naquilo que é da exclusiva competência da norma legislativa (lei em sentido formal e material). Assim sendo, o Regulamento jamais poderá instituir ou majorar tributos, criar cargos, aumentar vencimentos, perdoar 
dívidas ativas, conceder isenções tributárias e o mais que depender de lei propriamente dita".

"Regimentos: Os Regimentos são atos administrativos normativos de atuação interna, pois se destinam a reger o funcionamento de órgãos colegiados e de corporações legislativas. Como ato regulamentar interno, o Regimento só se dirige aos que devem executar o serviço ou realizar a atividade funcional regimentada, sem obrigar aos particulares em geral".

"São postos em vigência por resolução do corpo direto do órgão ou colegiado, através do hierárquico do executivo ou da capacidade de auto organização interna das corporações legislativas e judiciárias, razão pela qual só se dirigem aos que se acham sujeitos à disciplina do órgão que os expediu".

"Resoluções: são atos administrativos normativos expedidos pelas altas autoridades do Executivo (mas não pelo Chefe do Executivo, que só deve expedir Decretos) ou pelos Presidentes de tribunais, órgãos legislativos e colegiados administrativos, para disciplinar matéria de sua competência específica. Por exceção admitem-se Resoluções individuais".

"As Resoluções, normativas ou individuais, são sempre atos inferiores ao Regulamento e ao Regimento, não podendo invocá-los ou contrariá-los, mas unicamente complementá-los e explicá-los. Seus efeitos podem ser internos ou externos, conforme o campo de atuação da norma ou dos destinatários da providência concreta".

"Deliberações: são atos administrativos normativos ou decisórios emanados de órgãos colegiados. Quando normativas, são atos gerais; quando decisórias, são atos individuais".

"Aquelas são sempre superiores a estas, de modo que o órgão que as expediu não pode contrariá-las nas decisões subseqüentes: uma deliberação normativa só se revoga ou modifica por outra deliberação normativa; nunca por uma deliberação individual do mesmo órgão".

“As deliberações devem sempre obediência ao Regulamento e ao Regimento que houver para a organização e funcionamento do colegiado. Quando expedidas em conformidade com as normas superiores são vinculantes para a Administração e podem gerar direitos subjetivos para seus beneficiários".

\section{- Atos ordinatórios}

Segundo Meirelles ${ }^{10}$, servem estes atos para disciplinar o funcionamento da administração e a conduta de seu pessoal, orientando os funcionários no desempenho das suas atribuições. Dentre eles destacam-se:

"Instruções normativas: as instruções normativas são atos administrativos expedidos pelos Ministros de Estado para a execução das leis, Decretos e 
Regulamentos, mas são também utilizadas por outros órgãos superiores para o mesmo fim".

"Portarias: são atos administrativos internos, através dos quais os superiores hierárquicos oficializam determinações gerais aos seus subordinados".

\subsection{Constituição Brasileira e o Direito Nuclear}

O Direito Nuclear no Brasil tem origem no dispositivo constitucional que dá competência à União Federal para legislar sobre a matéria.

${\mathrm{A} \mathrm{CF}^{9}}^{9}$ de 1988 que se encontra em vigor, no que se refere às atividades e materiais nucleares, contém os seguintes preceitos:

“Art. 21. Compete à União:

XXIII - explorar os serviços e instalações nucleares de qualquer natureza e exercer monopólio estatal sobre a pesquisa, a lavra, o enriquecimento e reprocessamento, a industrialização e o comércio de minérios nucleares e seus derivados, atendidos os seguintes princípios e condições:

a) toda atividade nuclear em território nacional somente será admitida para fins pacíficos e mediante aprovação do Congresso Nacional;

b) sob regime de permissão, são autorizadas a comercialização e a utilização de radioisótopos para a pesquisa e usos médicos, agrícolas e industriais;

c) sob regime de permissão, são autorizadas a produção, comercialização e utilização de radioisótopos de meia-vida igual ou inferior a duas horas;

d) a responsabilidade civil por danos nucleares independe da existência de culpa;

“Art. 22. Compete privativamente à União legislar sobre:

XXVI - atividades nucleares de qualquer natureza; ,

"Art. 48. Cabe ao Congresso Nacional, com a sanção do Presidente da República, não exigida esta para o especificado nos arts. 49, 51 e 52, dispor sobre todas as matérias de competência da União, especialmente sobre:

IV - planos e programas nacionais, regionais e setoriais de desenvolvimento; ,

“Art. 49. É da competência exclusiva do Congresso Nacional:

XIV - aprovar iniciativas do Poder Executivo referentes a atividades nucleares; ",

“Art. 177. Constituem monopólio da União: 
V - a pesquisa, a lavra, o enriquecimento, o reprocessamento, a industrialização e o comércio de minérios e minerais nucleares e seus derivados, com exceção dos radioisótopos cuja produção, comercialização e utilização poderão ser autorizadas sob regime de permissão, conforme as alíneas b e c do inciso XXIII do caput do art. 21 desta Constituição Federal.

$\S 3^{\circ}$ A lei disporá sobre o transporte e a utilização de materiais radioativos no território nacional.

“Art. 200. Ao sistema único de saúde compete, além de outras atribuições, nos termos da lei:

VII - participar do controle e fiscalização da produção, transporte, guarda e utilização de substâncias e produtos psicoativos, tóxicos e radioativos; .."

"Art. 225. Todos têm direito ao meio ambiente ecologicamente equilibrado, bem de uso comum do povo e essencial à sadia qualidade de vida, impondo-se ao Poder Público e à coletividade o dever de defendê-lo e preservá-lo para as presentes e futuras gerações.

$\S 6^{\circ}$ - As usinas que operem com reator nuclear deverão ter sua localização definida em lei federal, sem o que não poderão ser instaladas.

Das disposições citadas, verifica-se que todas as atividades relacionadas à área nuclear são de competência exclusiva da União Federal. A única exceção é a utilização de radioisótopos para a pesquisa e usos medicinais, agrícolas, industriais e atividades análogas, que pode ser realizada por terceiros, por meio de permissão.

Já o transporte de material radioativo deverá ser regulamentado por lei, de acordo com o texto constitucional ${ }^{7}$.

\subsection{Legislação infraconstitucional brasileira}

Uma vez estabelecido o monopólio da União para as atividades nucleares, os dispositivos infraconstitucionais criaram as instituições e definiram as atribuições necessárias para seu exercício. A legislação principal que definiu o arranjo institucional do setor nuclear será abordada a seguir.

Pelo estudo da legislação vigente, verifica-se que os principais órgãos responsáveis pelo exercício do monopólio são a CNEN, a INB e a ELETRONUCLEAR. 
A Lei $4.118 / 62^{11}$, alterada pelas Leis $\mathrm{n}^{\mathrm{o}} 6.189 / 74^{12}$, e $\mathrm{n}^{\mathrm{o}} 6.571 / 78^{13}$, destaca-se pela criação da CNEN, como autarquia federal, de acordo com seu artigo $3^{\circ}$. Já a Lei $n^{\circ}$ $6.189 / 74^{12}$, modificada pela Lei $n^{0} 7.781 / 89^{14}$, estabelece, em seu artigo primeiro, que a União exercerá o monopólio sobre as atividades nucleares por meio da CNEN, como órgão superior de orientação, planejamento, supervisão, fiscalização e de pesquisa científica, e por meio da NUCLEBRAS e de suas subsidiárias, como órgãos de execução.

Em seu artigo segundo, a Lei $n^{\circ} 6.189 / 74^{12}$ define as competências da CNEN, que abrangem um amplo espectro relacionado à questão nuclear, como formulação de política, regulação, guarda de rejeitos radioativos, prestação de serviços, realização de pesquisas científicas e produção e comercialização de materiais e equipamentos, conforme transcrição a seguir:

Art. $2^{\circ}$ - Compete à CNEN:

I - colaborar na formulação da Política Nacional de Energia Nuclear;

II - baixar diretrizes específicas para radioproteção e segurança nuclear, atividade científico-tecnológica, industriais e demais aplicações nucleares;

III - elaborar e propor ao Conselho Superior de Política Nuclear (CSPN), Programa Nacional de Energia Nuclear;

IV - promover e incentivar:

a) a utilização da energia nuclear para fins pacíficos, nos diversos setores do desenvolvimento nacional;

b) a formação de cientistas, técnicos e especialistas nos setores relativos à energia nuclear;

c) a pesquisa científica e tecnológica no campo da energia nuclear;

d) a pesquisa e a lavra de minérios nucleares e seus associados;

e) o tratamento de minérios nucleares, seus associados e derivados;

f) a produção e o comércio de minérios nucleares, seus associados e derivados;

g) a produção e o comércio de materiais nucleares e outros equipamentos e materiais de interesse da energia nuclear;

h) a transferência de tecnologia nuclear a empresas industriais de capital nacional, mediante consórcio ou acordo comercial. 
$\mathrm{V}$ - negociar nos mercados interno e externo, bens e serviços de interesse nuclear;

VI - receber e depositar rejeitos radioativos;

VII - prestar serviços no campo dos usos pacíficos da energia nuclear;

VIII - estabelecer normas e conceder licenças e autorizações para o comércio interno e externo:

a) de minerais, minérios, materiais, equipamentos, projetos $\mathrm{e}$ transferência de tecnologia de interesse para a energia nuclear;

b) de Urânio cujo isótopo 235 ocorra em percentagem inferior ao encontrado na natureza;

IX - expedir normas, licenças e autorizações relativas a:

a) instalações nucleares;

b) posse, uso, armazenamento e transporte de material nuclear;

c) comercialização de material nuclear, minérios nucleares e concentrados que contenham elementos nucleares.

$\mathrm{X}$ - expedir regulamentos e normas de segurança e proteção relativas:

a) ao uso de instalações e de materiais nucleares;

b) ao transporte de materiais nucleares;

c) ao manuseio de materiais nucleares;

d) ao tratamento e à eliminação de rejeitos radioativos;

e) à construção e à operação de estabelecimentos destinados a produzir materiais nucleares e a utilizar energia nuclear.

XI - opinar sobre a concessão de patentes e licenças relacionadas com a utilização da energia nuclear;

XII - promover a organização e a instalação de laboratórios e instituições de pesquisa a elas subordinadas técnica e administrativamente, bem assim cooperar com instituições existentes no país com objetivos afins;

XIII - especificar:

a) os elementos que devam ser considerados nucleares, além do Urânio, Tório e Plutônio; 
b) os elementos que devam ser considerados material fértil e material físsil especial ou de interesse para a energia nuclear;

c) os minérios que devam ser considerados nucleares;

d) as instalações que devam ser consideradas nucleares.

XIV - fiscalizar:

a) o reconhecimento e o levantamento geológicos relacionados com minerais nucleares;

b) a pesquisa, a lavra e a industrialização de minérios nucleares;

c) a produção e o comércio de materiais nucleares;

d) a indústria de produção de materiais e equipamentos destinados ao desenvolvimento nuclear.

XV - pronunciar-se sobre projetos de tratados, acordos, convênios ou compromissos internacionais de qualquer espécie, relativos à energia nuclear;

XVI - produzir radioisótopos, substâncias radioativas e subprodutos nucleares, e exercer o respectivo comércio;

XVII - autorizar a utilização de radioisótopos para pesquisas e usos medicinais, agrícolas, industriais e atividades análogas;

XVIII - autorizar e fiscalizar a construção e a operação de instalações radioativas no que se refere às ações de comércio de radioisótopos.

Outras atribuições da CNEN, referentes a licenciamento, fiscalização, fixação de preços de materiais nucleares, estabelecimento e controle de estoque de materiais físseis e férteis e definição de reservas de minérios nucleares foram fixadas pelos artigos sétimo, oitavo, $10 .^{\circ}$ a $15 .^{\circ}$ e $17 .^{\circ}$ da Lei n. ${ }^{\circ} 6.189 / 74^{12}$. O artigo $19^{\circ}$, por sua vez, estabelece que a comercialização de materiais nucleares cabe exclusivamente à CNEN e a suas subsidiárias e controladas.

A Lei n. ${ }^{\circ}$ 5.740/71 ${ }^{15}$ autorizou a criação da Companhia Brasileira de Tecnologia Nuclear (CBTN), estatal cujo objeto foi definido no artigo terceiro, transcrito a seguir:

Art. 3. ${ }^{\circ}$ A CBTN, observado o disposto na Lei n. ${ }^{\circ} 4.118$, de 27 de agosto de 1962, e alterações posteriores terá por objeto:

I - Realizar a pesquisa e a lavra de jazidas de minérios nucleares e associados; 
II - Promover o desenvolvimento da tecnologia nuclear mediante a realização de pesquisas, estudos e projetos referentes à:

a) tratamento de minérios nucleares e associados bem como produção de elementos combustíveis e outros materiais de interesse da energia nuclear;

b) instalações de enriquecimento de urânio e de reprocessamento de elementos combustíveis nucleares irradiados;

c) componentes de reatores e outras instalações nucleares.

III - Promover a gradual assimilação da tecnologia nuclear pela indústria privada nacional;

IV - Construir e operar:

a) instalações de tratamento de minérios nucleares e seus associados;

b) instalações destinadas ao enriquecimento de Urânio, ao reprocessamento de elementos combustíveis irradiados, bem como à produção de elementos combustíveis e outros materiais de interesse da indústria nuclear.

V - Negociar, no mercado interno e externo, equipamentos, materiais e serviços de interesse da indústria nuclear.

VI - Dar apoio técnico e administrativo à CNEN.

Pelo artigo terceiro citado, constata-se que a principal atribuição da CBTN é desenvolver as atividades referentes ao ciclo do combustível nuclear, que abrange a mineração do Urânio, a produção do concentrado, a transformação para o estado gasoso, o enriquecimento, a reconversão para o estado sólido e a produção e o reprocessamento do combustivel nuclear.

A Lei $n .^{\circ} 6.189 / 74^{12}$, por meio de seu artigo $18 .^{\circ}$, determinou que a CBTN passasse a denominar-se NUCLEBRAS, diretamente vinculada ao MME.

Essa mesma Lei estabeleceu também que a NUCLEBRAS poderá, mediante autorização do Presidente da República, exportar, no mais alto grau de beneficiamento possível, os excedentes de minérios nucleares, de seus concentrados ou de compostos químicos de elementos nucleares, comprovada a existência dos estoques para a execução do Programa Nacional de Energia Nuclear.

Finalmente, o Decreto-Lei n. ${ }^{\circ} \quad 2.464 / 88^{16}$ alterou a denominação da NUCLEBRAS para INB e determinou a transferência da totalidade das ações de propriedade da União representativas do capital da INB para a CNEN. 
Outra entidade relacionada com as atividades nucleares é a Nuclebrás Equipamentos Pesados S.A. (NUCLEP), subsidiária da INB, cuja criação foi autorizada pelo Decreto n. ${ }^{\mathrm{o}} 76.805 / 75^{17}$. Seu objeto é projetar, desenvolver, fabricar e comercializar componentes pesados relativos a usinas nucleares e a outros projetos correlacionados.

Em relação à geração de eletricidade, o artigo $10 .^{\circ}$ da Lei n. $^{\circ} 6.189 / 74^{12}$ estabelece que:

[...] a autorização para a construção e operação de usinas núcleo elétricas será dada, exclusivamente, a Centrais Elétricas Brasileiras S/A, ELETROBRAS e as concessionárias de serviços de energia elétrica, mediante ato do Poder Executivo, previamente ouvidos os órgãos competentes.

A empresa responsável pela geração de eletricidade a partir da energia nuclear é a Eletrobrás Termonuclear S.A. (ELETRONUCLEAR), subsidiária da ELETROBRAS. A ELETRONUCLEAR é resultado da fusão - autorizada pelo Decreto sem número de 23/05/1997 ${ }^{18}$ da área nuclear de Furnas Centrais Elétricas S.A. (FURNAS), responsável pela operação das Usinas Angra 1 e 2, com a Nuclen - Engenharia e Serviços S.A. (NUCLEN), anteriormente uma empresa de projetos de engenharia para a área nuclear, subsidiária da INB. A ELETRONUCLEAR, cuja denominação foi estabelecida pelo Decreto sem número de 23/12/1997 ${ }^{19}$ tem como principal objetivo a construção e operação de usinas nucleares e a geração, transmissão e comercialização da energia elétrica por elas produzida, conforme dispõe o Decreto n. ${ }^{\text { }} 4.899$, de 26 de novembro de $2003^{20}$.

Outra legislação de destaque no cenário nuclear é a Lei n. ${ }^{\circ} 10.308 / 2001^{21}$, que dispõe sobre a seleção de locais, a construção, o licenciamento, a operação, a fiscalização, os custos, a indenização, a responsabilidade civil e as garantias referentes aos depósitos de rejeitos radioativos.

De acordo com o artigo segundo dessa lei, a União, por meio da CNEN, é a responsável pelo destino final dos rejeitos radioativos produzidos em território nacional.

Ainda em conformidade com a Lei n. ${ }^{\circ} 10.308 / 2001^{21}$, artigos nono e $13 .{ }^{\circ}$, cabe à CNEN projetar, construir administrar e operar os depósitos finais e intermediários, podendo delegar essas atribuições a terceiros. O artigo $15 .^{\circ}$ dispõe que é também da Comissão a responsabilidade pela remoção de rejeitos dos depósitos intermediários para os finais.

Já a construção e operação dos depósitos iniciais, bem como a remoção de rejeitos desses depósitos para os intermediários e finais é de responsabilidade dos 
produtores dos resíduos, conforme estipula os artigos oitavo, $12 .^{\circ}$ e $14 .^{\circ}$ da mesma Lei n. ${ }^{\circ}$ $10.308 / 2001^{21}$.

Ressalta-se que cabe também à CNEN definir as normas, licenciar e fiscalizar todos os tipos de depósitos de rejeitos radioativos, de acordo com os artigos quarto e 11..

A Lei n. ${ }^{\circ} 10.308 / 2001^{21}$, em seu artigo $18 .^{\circ}$, também prevê que os custos dos depósitos intermediários e finais serão pagos à CNEN pelo depositante, isto é, aquele que gera os rejeitos.

Cabe ainda destacar que o artigo $35 .^{\circ}$ da referida Lei determina que os órgãos responsáveis pela sua fiscalização enviarão anualmente ao Congresso Nacional relatório sobre a situação dos depósitos de rejeitos radioativos.

Observa-se que a previsão constitucional de que a lei disporá sobre o transporte de material radioativo ainda não se concretizou. Sendo assim, essa atividade é regulada por normas da CNEN, a saber:

- NE - 5.01 Transporte de materiais radioativos ${ }^{22}$.

- NE - 5.02 Transporte, recebimento, armazenagem e manuseio de elementos combustíveis de usinas nucleoelétricas ${ }^{23}$.

Quanto à pesquisa e lavra de minérios nucleares, como já mencionado, aplicase o monopólio da União, fixado no artigo $177 .^{\circ}$ da $\mathrm{CF}^{9}$. A competência para definição de normas, licenciamento e fiscalização é da CNEN, de acordo com os dispositivos da Lei n. ${ }^{\circ}$ $6.189 / 74^{12}$ já apresentados. Da mesma forma, já foi mostrado que a Lei n. ${ }^{\text {o }} 5.740 / 71^{16}$ estipulou que é da INB e de suas subsidiárias a atribuição de executar a pesquisa e lavra desses minerais. Cabe, no entanto, mencionar ainda que a INB e suas subsidiárias deverão seguir os procedimentos previstos no Decreto-lei n. ${ }^{\circ} 1.865 / 81^{24}$, quanto à ocupação provisória de imóveis para pesquisa e lavra de substâncias minerais que contenham elementos nucleares.

Se, entretanto, um autorizado de pesquisa ou concessionário de lavra referente a outros tipos de minério encontrar material nuclear, aplica-se o disposto nos artigos quarto, quinto e sexto da Lei n. ${ }^{\circ} 6.189 / 74^{12}$, a saber:

Art. 4. ${ }^{\circ} \mathrm{Na}$ pesquisa autorizada ou na lavra concedida, a ocorrência de elementos nucleares obriga o titular a comunicar o fato prontamente ao Ministério das Minas e Energia, sob pena da caducidade da autorização de pesquisa ou de concessão de lavra.

Parágrafo único. A CNEN e o Departamento Nacional da Produção Mineral, em colaboração, exercerão sobre as atividades dos respectivos titulares a fiscalização prevista em Lei. 
Art. 5. ${ }^{\circ}$ Verificada a ocorrência de Urânio ou Tório em quantidade de valor econômico superior ao da substância mineral pesquisada ou lavrada, a jazida será incluída no monopólio e a CNEN, além do reembolso das despesas efetivamente realizadas ou indenizações cabíveis, poderá conceder ao titular um prêmio condizente com o valor da descoberta, na forma a ser regulamentada.

Art. 6. ${ }^{\circ}$ Verificada a ocorrência de Urânio ou Tório em quantidade de valor econômico inferior ao da substância mineral pesquisada ou lavrada, a autorização de pesquisa será concedida ou mantida, obedecidas as seguintes disposições:

I - o titular ficará obrigado, quando a CNEN o exigir, a efetuar a separação e a entrega à CNEN do Urânio ou Tório contido no minério extraído;

II - quando a separação do Urânio ou Tório impuser despesas adicionais, ou quando a entrega do produto separado for feita sob a forma de concentrados ou compostos químicos, o titular fará jus ao pagamento estabelecido pela CNEN, na forma a ser regulamentada;

III - quando a separação for considerada pela CNEN inviável para o concessionário, este devolverá à $\mathrm{CNEN}$, por aquisição no mercado externo, concentrados ou compostos químicos contendo quantidades de materiais físseis ou férteis, estabelecidas pela CNEN, com base nos existentes no material extraído. A devolução deverá ser feita, a critério da CNEN, na forma a ser regulamentada;

IV - quando, na hipótese do item III, não for possível ou conveniente adquirir no mercado externo concentrados ou compostos químicos, a forma de devolução ficará a critério da CNEN que estabelecerá, se for o caso, as condições de recolhimento, em moeda corrente, do valor correspondente.

\subsection{Legislação Internacional}

A legislação internacional constitui-se de instrumentos legais de natureza bilateral ou multilateral aos quais o Brasil, ao ratificar, se sujeita a cumprir. Estes instrumentos são criados por meio de acordos, tratados ou convenções estabelecidos com parceiros ou em foros internacionais para regulamentar uma determinada atividade. São alguns exemplos:

a) O Tratado de Tlatelolco, que estabelece a proibição de armas nucleares na América Latina e regulamenta a posse e o uso de materiais sensíveis às salvaguardas, em que alguns tipos de rejeitos estão incluídos.

b) A Convenção sobre Notificação de Acidente Nuclear, que obriga o país a informar sobre a ocorrência de acidente nuclear. 
c) A Convenção sobre Assistência em Caso de Acidente Nuclear ou Emergência Radiológica, que obriga a prestação de assistência, material e técnica, ao país sob emergência radiológica.

d) A Convenção sobre Proteção Física de Material Nuclear, que estabelece regras para controle e segurança de materiais nucleares.

e) A Convenção sobre a Prevenção de Poluição Marinha, que proíbe o despejo ou disposição de rejeitos radioativos no mar.

f) Convenção Internacional sobre Transporte de Materiais Radioativos.

g) Convenção Internacional sobre Rejeitos Radioativos.

h) Tratado de Não Proliferação, do qual o Brasil é signatário. 


\section{MARCO REGULATÓRIO}

\subsection{Regulação na área nuclear}

No âmbito internacional, a regulação na área nuclear é responsabilidade da AIEA, que estabelece recomendações aos países membros quanto às responsabilidades e atividades regulatórias de cada país, e cujo principal objetivo é a cooperação científica e técnica do uso pacífico da tecnologia nuclear.

Segundo Almeida ${ }^{25}$, a AIEA, através do documento Legal and Governmental Infrastructure for Nuclear, Radiation, Radioactive Wast and Transportation Safety Requirements, define as funções dos órgãos reguladores em:

- Autorização;

- Revisão e avaliação;

- Inspeção e ações coercitivas;

- Desenvolvimento de regulamentos e guias.

Além dessas, outras funções complementares são atribuídas ao órgão regulador, como a preparação para emergências, a pesquisa e o desenvolvimento associado às funções regulatórias e a cooperação internacional.

A regulação da área nuclear é formada pela radioproteção e pela seguridade. A proteção abrange as técnicas, teorias e práticas para o reconhecimento de efeitos negativos em situações normais de trabalho, e de radiações ionizantes, buscando a proteção do ser humano e do meio ambiente desses efeitos; a seguridade abrange técnicas, teorias e práticas relacionadas aos sistemas que utilizam fonte de radiação e de proteção física das fontes de radiação, fazendo com que estes atuem de forma segura ${ }^{25}$.

\subsection{Regulação nuclear no Brasil}

A regulação nuclear no Brasil aconteceu à medida que a tecnologia nuclear era introduzida, com as áreas de radioproteção e seguridade sendo implantadas em tempos diversos ${ }^{25}$.

Em relação à segurança nuclear, com a aquisição da primeira usina de potência, no início da década de 1970 e, devido à complexidade do sistema, três resoluções foram emitidas pela CNEN: Escolha de locais para instalação de reatores de potência (CNEN 09/69), para licenciamento de reatores de potência (CNEN 06/72) e, proteção radiológica (CNEN 06/73) $)^{26-28}$.

A área de radioproteção teve sua regulação de forma evolutiva, tendo a prática 
antecedido a regulação, pois métodos e equipamentos foram sendo introduzidos no país sem a existência de um órgão regulador, incorporando recomendações da Atomic Energy Agency (AEC), da International Commission on Radiological Protection (ICRP), e da AIEA, sendo a Resolução CNEN $11 / 69^{29}$ a primeira norma nessa área, estabelecendo a obrigatoriedade de "[...] aprovação prévia do projeto pela CNEN para a importação de fontes para teleterapia."

O acidente com Césio 137, ocorrido na cidade de Goiânia em 1987, além de demonstrar a ineficácia do sistema de fiscalização nacional, provocou o levantamento de fontes radioativas artificiais existentes no país, seu cadastramento e de seus responsáveis, criando "[...] uma competência nacional no processo de atendimento a emergências e no estudo da radioproteção, que acabou colocando o sistema brasileiro de controle de instalações radiativas em posição de destaque internacional ${ }^{25}$."

\subsection{Controle regulatório exercido no Brasil}

O órgão regulador nuclear no Brasil é a CNEN, autarquia federal, vinculada ao MCT.

O controle regulatório exercido na área nuclear brasileira abrange o controle das instalações nucleares e radiativas e o controle da importação e exportação de minérios e materiais nucleares ou de interesse nuclear. $\mathrm{O}$ controle regulatório iniciou-se com a finalidade de evitar que os minérios de interesse estratégico para atividades nucleares fossem levados do país, sendo estendido para os objetivos de seguridade e radioproteção, que hoje predominam. Das atividades com radiações ionizantes, somente o controle regulatório das atividades com raios $\mathrm{X}$ diagnóstico não é exercido pela $\mathrm{CNEN}$, função de que foram encarregadas as autoridades do Ministério da Saúde (MS). Ainda assim, cabe à CNEN a emissão das diretrizes de radioproteção que devem ser seguidas também por estas atividades.

O processo regulatório é estabelecido com base em normas da CNEN, que são regulamentos técnicos com valor compulsório. As autorizações são dadas em conformidade com o principio de atribuir responsabilidade a uma pessoa física ou jurídica, e sua concessão é feita após a verificação do atendimento do requerente aos requisitos de recursos humanos, instalações, sistemas, dispositivos, equipamentos e procedimentos previstos na regulamentação definitiva pelo órgão regulador. O autorizado é o responsável primeiro pela seguridade e radioproteção dos trabalhadores, do público e do meio ambiente. Para serem aceitas, as ligações entre as pessoas físicas responsáveis pela instalação ou prática e a organização devem ser comprovadas através de documentos 
oficiais como, por exemplo, contrato de trabalho, participação acionária, entre outros. As transferências de controle de fontes ou mudança de pessoas responsáveis devem ser necessariamente informadas ao órgão regulador.

Outro ponto fundamental do controle regulatório nuclear no Brasil é o exercício do controle da importação, exportação e utilização de material ou equipamentos sob controle regulatório. Graças a um sistema que envolve a Receita Federal do MF, o Sistema Integrado de Comércio Exterior (SISCOMEX), a importação de materiais e equipamentos controlados só pode ocorrer com a autorização prévia do órgão regulador nuclear. No Brasil, a produção de material radioativo e a exploração de materiais nucleares é monopólio estatal federal estabelecido pela $\mathrm{CF}^{9}$. Dessa forma, os materiais radioativos produzidos no país como radiofármacos e fontes para gamagrafia industrial, também só é disponibilizado mediante o atendimento das condições de conformidade com os requisitos exigidos pelo órgão regulador. A autorização dada pelo órgão regulador nuclear não substitui as demais autorizações requeridas pela legislação.

O órgão regulador nuclear também mantém um banco de dados com os registros de doses ocupacionais dos trabalhadores na área de radiação ionizante. Essas informações são fornecidas pelos serviços de monitoração dosimétrica pessoal, que passam por um processo de certificação realizado pelo Instituto de Radioproteção e Dosimetria (IRD), e tornam-se qualificados para atender os requisitos de monitoração pessoal do órgão regulador e também do MS. O banco de dados de doses é administrado pelo IRD. No caso de doses acima de determinados limites, a empresa regulada responsável pelo trabalhador e o serviço de monitoração são obrigados a notificar o órgão regulador e justificar o evento, que poderá ser objeto de uma investigação.

O órgão regulador nuclear mantém o Sistema de Atendimento de Emergências Radiológicas (SAER), com funcionamento 24 horas por dia, coordenado pelo IRD. Além do IRD, estão integrados a esse sistema, 12 das 13 unidades da CNEN, situadas em nove Estados brasileiros. Além disso, em virtude de uma Convenção, que o país assinou junto a AIEA, faz parte dos países membros de cooperação mutua entre eles. Esta cooperação foi utilizada em Goiânia (GO).

As instalações nucleares são obrigadas a ter programas de monitoração ambiental, que são acompanhados pelo órgão regulador. Periodicamente o órgão regulador faz a verificação de medidas para se assegurar do correto funcionamento do sistema.

Para funções consideradas chaves no processo de radioproteção e seguridade, o órgão regulador faz a certificação da qualificação da pessoa física. Isso se aplica a 
supervisores de proteção radiológica dos diversos tipos de instalação e para operadores de reatores de potência ou de pesquisa ${ }^{25}$.

A AIEA realizou, no período de 13 a 17 de novembro de 2006, uma auditoria na CNEN no tocante à infra-estrutura de seguridade radiológica e controle de fontes radioativas. Em relatório, encaminhado às autoridades competentes do país, fez uma avaliação, referente ao sistema legislativo e de organização do órgão regulador, onde ressaltamos as seguintes conclusões e recomendações:

O governo brasileiro deverá fazer uma revisão na legislação do país com o objetivo de fortalecer a eficácia, eficiência e a efetiva independência do órgão regulador, em conformidade com os padrões internacionais, com o Código de Conduta de Segurança de Fontes Radioativas e com a existente legislação nacional, assim como incluir várias das funções realizadas pela CNEN que não têm respaldo na legislação nacional. Neste ponto o relatório é claro em apresentar que a legislação nacional não estabelece a efetiva independência do órgão regulador, uma vez que a CNEN realiza a promoção e o fornecimento de serviços na área nuclear ${ }^{30}$. 


\section{FORMAÇÃO DO ESPAÇO EUROPEU}

\subsection{Principais instituições encarregadas da legislação e das políticas comunitárias}

A UE é mais do que uma confederação de Estados, mas não é um Estado federal. Na realidade, é algo inteiramente novo e historicamente único. O seu sistema político tem evoluído constantemente ao longo dos últimos 50 anos e tem por base uma série de Tratados, desde os que foram assinados em Paris e Roma na década de 50 até aos de Maastricht, Amsterdam e Nice, da década de 90. Nos termos destes tratados, os Estados-Membros da UE delegam parte da sua soberania nacional em instituições comuns, que representam tanto os interesses nacionais como os interesses comunitários. Os Tratados constituem o chamado "direito primário", que está na origem de um vasto corpo de "direito derivado", que tem incidência direta na vida quotidiana dos cidadãos europeus. Este último consiste, principalmente, em regulamentos, diretivas e recomendações. Esta legislação, tal como as políticas comunitárias em geral, é o resultado de decisões tomadas por três principais instituições, o Parlamento Europeu; o Conselho da UE e a Comissão Europeia $^{31}$.

\subsubsection{Parlamento Europeu}

O Parlamento Europeu é o órgão eleito que representa os cidadãos da UE e participa no processo legislativo. Desde 1979, os seus membros são eleitos por sufrágio direto e universal, de cinco em cinco anos.

O Parlamento realiza normalmente sessões plenárias em Estrasburgo, França e ainda algumas sessões adicionais em Bruxelas, Bélgica. As suas 17 comissões, que preparam as sessões plenárias, e os seus grupos políticos reúnem-se geralmente em Bruxelas. O Secretariado-Geral está sediado em Luxemburgo ${ }^{31}$.

\subsubsection{Conselho da UE}

O Conselho da UE é a principal instituição decisória da UE, e quem representa os Estados-Membros. Anteriormente, era designado "Conselho de Ministros", e o mais freqüente é designá-lo simplesmente por "Conselho".

Cada Estado-Membro da UE exerce rotativamente a Presidência do Conselho, por um período de seis meses. Nas reuniões do Conselho participa um ministro de cada Estado-Membro. Os ministros participantes variam em função da matéria inscrita na ordem de trabalhos: negócios estrangeiros, agricultura, indústria, transportes, ambiente, entre outros. Há nove diferentes formações do Conselho. Os trabalhos do Conselho no seu 
conjunto são preparados e coordenados pelo Conselho Assuntos Gerais e Relações Externas.

As reuniões do Conselho são preparadas pelo Comitê dos Representantes Permanentes (COREPER), formado pelos embaixadores dos Estados-Membros junto da UE, assistidos por funcionários dos ministérios nacionais. O trabalho administrativo é assegurado pelo Secretariado-Geral, em Bruxelas ${ }^{31}$.

\subsubsection{Comissão Europeia}

A Comissão Europeia é um órgão politicamente independente que representa os interesses gerais dos europeus.

A Comissão é uma das instituições-chave da UE. É composta por 27 membros, havendo um comissário por país, nomeados para um mandato de cinco anos por acordo entre os Estados-Membros, sujeito a aprovação do Parlamento.

A Comissão goza de total independência política. A sua missão é defender os interesses da UE no seu conjunto, pelo que não pode sofrer pressões de qualquer governo dos Estados-Membros. Enquanto "guardiã dos tratados", deve assegurar que os regulamentos e diretivas adotados pelo Conselho e pelo Parlamento sejam aplicados. Se não forem, a Comissão pode recorrer ao Tribunal de Justiça para impor a aplicação do direito comunitário.

A Comissão dispõe do monopólio da iniciativa legislativa e pode intervir a qualquer momento para ajudar a encontrar um acordo tanto em nível do Conselho como entre o Conselho e o Parlamento.

Como órgão executivo da UE, a Comissão aplica as decisões tomadas pelo Conselho, por exemplo, no domínio da política agrícola comum. Dispõe de amplos poderes na condução das políticas comuns da UE: investigação, cooperação para o desenvolvimento, política regional, entre outras, cujos orçamentos the estão confiados.

A Comissão é responsável perante o Parlamento e é obrigada a demitir-se em bloco se for objeto de uma moção de censura aprovada por esse.

A Comissão dispõe de uma administração composta por 36 direções-gerais e serviços, sediados principalmente em Bruxelas e em Luxemburgo ${ }^{31}$.

O Conselho e o Parlamento Europeu partilham o poder legislativo e a responsabilidade pelo orçamento. É o Conselho que celebra os acordos internacionais negociados pela Comissão. Segundo os Tratados, o Conselho delibera por unanimidade, por maioria simples ou por maioria qualificada. 
O Parlamento e o Conselho partilham o poder legislativo, seguindo três processos diferentes (além da simples consulta).

O primeiro é o procedimento de cooperação, introduzido em 1986 pelo Ato Único Europeu. Segundo esse procedimento, o Parlamento pronuncia-se sobre as propostas de diretivas e de regulamentos da Comissão, que pode alterar as suas propostas para ter em conta a posição do Parlamento.

O segundo é o procedimento de parecer favorável, também introduzido em 1986. Segundo esse, o Parlamento tem de dar o seu parecer favorável a acordos internacionais negociados pela Comissão e a propostas de ampliação da UE, bem como numa série de outras matérias, como a alteração das regras eleitorais.

O terceiro é o procedimento de co-decisão, introduzido pelo Tratado de Maastricht (1992). Esse coloca o Parlamento em igualdade com o Conselho quando é preciso legislar em uma série de domínios importantes, como a livre circulação dos trabalhadores, o mercado interno, a educação, a investigação, o ambiente, as redes trans européias, a saúde, a cultura e a defesa dos consumidores. O Parlamento tem poderes para rejeitar propostas legislativas nesses domínios, se a maioria absoluta dos seus membros votarem contra a posição comum do Conselho. Nesse caso, a questão pode transitar para um comitê de conciliação.

O Tratado de Amsterdam acrescentou 23 e o Tratado de Nice mais sete ao número de domínios em que se aplica o procedimento de co-decisão.

O Parlamento e o Conselho partilham idênticas responsabilidades na adoção do orçamento comunitário. A Comissão Europeia propõe um projeto de orçamento, que depois é discutido no Parlamento e no Conselho. O Parlamento pode rejeitar o orçamento proposto, o que já fez em diversas ocasiões. Quando isto acontece, tem de ser reiniciado todo o processo orçamentário. O Parlamento tem utilizado plenamente as suas competências orçamentárias para influenciar as políticas comunitárias. No entanto, a maior parte das despesas agrícolas comunitárias escapa ao controle do Parlamento.

O Parlamento é uma força impulsionadora das políticas comunitárias. Constitui o fórum de discussão por excelência da UE, o local onde os pontos de vista políticos e nacionais de todos os Estados-Membros se encontram e se cruzam.

Assim, o Parlamento é, naturalmente, o local de origem de muitas iniciativas políticas.

Os debates parlamentares são dominados pelos grupos políticos, dos quais os maiores são: 
- O Grupo do Partido Popular Europeu (democrata-cristão) e Democratas Europeus - PPE-DE;

- O Grupo do Partido dos Socialistas Europeus - PSE.

Por último, mas não menos importante, o Parlamento é o órgão de controle democrático da UE. Tem o poder de demitir a Comissão, aprovando uma moção de censura por uma maioria de dois terços dos seus membros. Controla a gestão e execução das políticas comunitárias, especificamente analisando os relatórios que lhe são enviados pelo Tribunal de Contas e formulando perguntas orais e escritas à Comissão e ao Conselho. O presidente em exercício do Conselho Europeu também informa o Parlamento das decisões tomadas por aquela instância.

Este "triângulo institucional" só pode funcionar mediante uma cooperação estreita e em uma base de confiança entre as três instituições. "Para o desempenho das suas atribuições e nos termos do presente Tratado, o Parlamento em conjunto com o Conselho, o Conselho e a Comissão adotam regulamentos e diretivas, tomam decisões e formulam recomendações ou pareceres" (artigo 249. ${ }^{\circ}$ do Tratado CE) 32.

\subsection{Ordenamento jurídico}

O ordenamento jurídico comunitário vigente na UE é composto pelo direito originário (fontes primárias) e pelo direito derivado (fontes secundárias), pela jurisprudência e pelos princípios gerais de direito ${ }^{33}$.

\subsubsection{Tratados}

Os Tratados constituem o direito primário da UE, sendo por isso comparável ao direito constitucional em nível nacional. Assim, os Tratados definem os elementos fundamentais da UE, designadamente as competências dos intervenientes do sistema comunitário que participam no processo de decisão, os procedimentos legislativos, bem como os poderes que lhes são conferidos. Os Tratados são objeto de negociações diretas entre os governos dos Estados-Membros e devem seguidamente ser ratificados segundo os procedimentos previstos em nível nacional (em princípio, pelos parlamentos nacionais ou por meio de referendo) ${ }^{33 .}$

\subsubsection{Acordos internacionais}

Os acordos internacionais são a segunda fonte de direito da UE e permitem-lhe desenvolver as suas relações econômicas, sociais e políticas com o resto do mundo. Tratase sempre de acordos celebrados entre sujeitos de direito internacional (Estados-Membros ou organizações) que têm por objetivo estabelecer uma cooperação em nível internacional. Os acordos celebrados pela UE no âmbito do primeiro pilar vinculam as instituições da UE 
e os Estados-Membros. Os acordos celebrados pela UE no âmbito dos segundo e terceiro pilares vinculam as instituições, mas nem sempre os Estados-Membros.

Entre os primeiros, é possível distinguir dois tipos principais de acordos:

- Os acordos internacionais com países terceiros ou organizações internacionais

- Os acordos e convenções entre os Estados-Membros ${ }^{33}$.

\subsubsection{Acordos com países terceiros ou organizações internacionais}

Estes acordos podem ser celebrados pela Comunidade ou pela Comunidade com os Estados-Membros (acordo misto). São vinculativos para a Comunidade e para os Estados-Membros, pelo que comprometem a sua responsabilidade em nível internacional. Existem três formas de acordos:

- Acordos de associação

A associação prende-se com uma cooperação econômica estreita, ligada a um vasto apoio financeiro da Comunidade em benefício do parceiro no acordo. Desta categoria fazem parte os acordos com as regiões e os territórios ultramarinos, os acordos que visam preparar uma adesão e criar uma união aduaneira e o acordo sobre o Espaço Econômico Europeu (EEE).

- Acordos de cooperação

Os acordos de cooperação não têm o mesmo alcance do que os acordos de associação, na medida em que visam unicamente uma cooperação econômica intensiva. São acordos desta natureza que ligam a Comunidade, por exemplo, com os Estados do Magrebe (Argélia, Marrocos e Tunísia), os Estados do Machrek (Egito, Jordânia, Líbano e Síria) e Israel.

- Acordos comerciais

Estes são acordos em matéria de política aduaneira e comercial celebrados com países terceiros, grupos de países terceiros ou no âmbito de organizações comerciais internacionais. O acordo que institui a Organização Mundial do Comércio (OMC) pertence a esta categoria ${ }^{33}$.

\subsubsection{Acordos entre os Estados-Membros}

Trata-se de atos jurídicos vinculativos celebrados pelos Estados-Membros, com vista à resolução de questões relacionadas com as atividades da Comunidade, mas que não se enquadram nos domínios de competência das instituições comunitárias, ou de atos que permitem ampliar os limites territoriais de disposições nacionais, no intuito de criar um 
direito homogêneo à escala da Comunidade (por exemplo, o acordo relativo à patente comunitária) $)^{33}$.

\subsubsection{Direito derivado}

O direito derivado constitui a terceira fonte importante do direito comunitário, depois dos Tratados (direito primário) e dos acordos internacionais. Pode ser definido como o conjunto dos atos normativos adotados pelas instituições europeias em aplicação das disposições dos Tratados. Fazem parte do direito derivado os atos jurídicos vinculativos (regulamentos, diretivas e decisões) e não vinculativos (resoluções, pareceres) previstos no Tratado CE, mas também todo um leque de outros atos, por exemplo, os regulamentos internos das instituições ou os programas de ação comunitários.

Os instrumentos jurídicos dos segundo e terceiro pilares, embora não façam propriamente parte do direito derivado, já que se mantêm na esfera das relações intergovernamentais, foram incluídos nesta categoria por razões documentais ${ }^{34}$.

\subsubsection{Regulamento}

Aprovado pelo Conselho, juntamente com o Parlamento, ou apenas pela Comissão, o regulamento é um ato geral e obrigatório em todos os seus elementos. Ao contrário das diretivas, que se dirigem aos Estados-Membros, e das decisões, que têm destinatários bem definidos, o regulamento dirige-se a todos.

É diretamente aplicável, ou seja, as suas disposições têm efeito jurídico imediato em todos os Estados-Membros da mesma forma que uma lei nacional, e isto sem intervenção das autoridades nacionais ${ }^{34}$.

\subsubsection{Diretiva}

Aprovada pelo Conselho, juntamente com o Parlamento, ou apenas pela Comissão, a diretiva dirige-se aos Estados-Membros. O seu principal objetivo reside na aproximação das legislações.

A diretiva vincula os Estados-Membros no que respeita ao resultado a atingir, mas permite-lhes escolher a forma e os meios que privilegiarão para alcançar as metas comunitárias, no âmbito dos respectivos ordenamentos jurídicos internos.

Se os Estados-Membros não transpuserem a diretiva para a legislação nacional, ou se o fizerem de forma incompleta ou com atrasos, os interessados podem invocar diretamente a diretiva em questão nos tribunais nacionais ${ }^{34}$.

\subsubsection{Decisão}

Aprovada pelo Conselho apenas, pelo Conselho juntamente com o Parlamento Europeu ou só pela Comissão, a decisão é o ato por meio do qual as instituições 
comunitárias deliberam sobre casos específicos. Através de uma decisão, as instituições podem exigir que um Estado-Membro ou um cidadão da UE aja ou se abstenha de agir, conferir-lhe direitos ou impor-lhe obrigações.

A decisão é:

- individual e os destinatários de uma decisão devem ser designados individualmente, o que a distingue do regulamento

- e obrigatória em todos os seus elementos ${ }^{34}$.

\subsubsection{Recomendação}

A recomendação permite às instituições manifestarem-se, sugerindo uma linha de conduta sem sujeitarem os destinatários (os Estados-Membros, outras instituições, em determinados casos, também os cidadãos da UE) a uma obrigação jurídica ${ }^{34}$.

\subsubsection{Parecer}

O parecer é um ato que permite às instituições pronunciarem-se de forma não vinculativa, isto é, sem sujeitarem os seus destinatários a uma obrigação jurídica. O seu objetivo consiste em expor o ponto de vista da instituição sobre uma determinada questão ${ }^{34}$.

\subsubsection{Ação comum}

A ação comum é um instrumento jurídico do título $\mathrm{V}$ do Tratado da UE. É, portanto, um ato de tipo intergovernamental. Adotada pelo Conselho da UE por unanimidade ou, em determinados casos, por maioria qualificada, a ação comum é vinculativa para os Estados-Membros, que devem atingir os objetivos nela fixados, exceto em caso de dificuldades importantes ${ }^{34}$.

\subsubsection{Decisão, decisão-quadro e ação comum}

A decisão e a decisão-quadro substituem, desde a entrada em vigor do Tratado de Amsterdam, a ação comum no domínio da cooperação policial e judiciária em matéria penal. Trata-se de instrumentos jurídicos do Título VI do Tratado da UE que são de tipo intergovernamental. A decisão e a decisão-quadro são adotadas pelo Conselho da UE por unanimidade, por iniciativa da Comissão ou de um Estado-Membro.

- A decisão-quadro vincula os Estados-Membros quanto ao resultado a atingir, deixando às instâncias nacionais a liberdade de escolher a forma e os meios para esse efeito (como a diretiva no domínio comunitário).

- A decisão é utilizada para alcançar qualquer objetivo de cooperação policial e judiciária em matéria penal, com exceção da aproximação das disposições legislativas e regulamentares dos Estados-Membros, missão reservada à decisão-quadro ${ }^{34}$. 


\subsubsection{Posição comum}

A posição comum em matéria de política externa e de segurança comum e de cooperação policial e judiciária em matéria penal é um instrumento jurídico de tipo intergovernamental, previsto nos Títulos V e VI do Tratado da UE. Adotada por unanimidade pelo Conselho da UE, define a abordagem da UE em determinadas questões da política externa e de segurança comum ou da cooperação policial e judiciária em matéria penal, fornecendo uma orientação para a execução das políticas nacionais nos domínios em causa ${ }^{34}$.

\subsubsection{Acordo internacional}

Trata-se de um instrumento jurídico dos Títulos V e VI do Tratado da UE que não estava previsto no Tratado de Maastricht. No que diz respeito aos segundo e terceiro pilares, não existia uma base jurídica para celebrar acordos internacionais. O Tratado de Amsterdam, para evitar que cada acordo assinado pelo Conselho tivesse de ser formalmente celebrado pelos Estados-Membros, previu a possibilidade de o Conselho autorizar a Presidência a conduzir negociações sempre que necessário.

Os acordos vinculam as instituições da UE, mas não os Estados-Membros cujas normas constitucionais prevêem regras específicas para a sua celebração. Ainda assim, nestes casos, os demais Estados-Membros no Conselho podem ajustar-se no sentido de que o acordo seja aplicável a título provisório ${ }^{34}$.

\subsubsection{Jurisprudência}

Fonte formal e relevante do direito comunitário, constituída pelo conjunto de decisões do Tribunal de Justiça das Comunidades Europeias ${ }^{34}$.

\subsubsection{Princípios gerais de direito}

São regras jurídicas não escritas, comuns e aceitas pelos sistemas jurídicos, constituindo os suportes estruturais do sistema normativo ${ }^{35}$.

\subsubsection{Tribunal de Justiça das Comunidades Européias}

O Tribunal de Justiça das Comunidades Européias, com sede em Luxemburgo constitui a instituição jurisdicional comunitária. É composto por três órgãos: o Tribunal de Justiça, o Tribunal de Primeira Instância e o Tribunal da Função Pública. A missão essencial da instituição consiste em apreciar a legalidade dos atos comunitários e assegurar a interpretação e aplicação uniformes do direito comunitário.

No âmbito desta missão, o Tribunal de Justiça das Comunidades Européias: fiscaliza a legalidade dos atos das instituições da União Europeia; assegura o respeito, 
pelos Estados-Membros, das obrigações comunitárias que lhes incumbem; interpreta o direito comunitário a pedido dos juízes nacionais ${ }^{35}$. 


\section{PANORAMA DA ENERGIA NUCLEAR NA EUROPA}

A UE é a maior produtora mundial de eletricidade de origem nuclear $(944,2$ TWh(e) em 2005). Cerca de um terço da eletricidade e 15\% da energia consumidas na UE provêm de centrais nucleares. Em 2006, existiam no mundo 443 reatores nucleares de produção de eletricidade que forneciam 15\% da eletricidade mundial. No final de 2006, a UE contava com 152 reatores, 146 desde Janeiro de 2007 repartidos por 15 EstadosMembros, cuja média de idade era de 25 anos aproximadamente, sendo o período de vida normal de 40 anos.

Por conseguinte, nos próximos anos há que se adotar decisões relativas à renovação do parque nuclear europeu ou à prorrogação da duração de vida de certas centrais, tendo em conta o tempo necessário para a construção de novos reatores nucleares.

Vários países terceiros comunicaram a sua intenção de construir novas instalações de produção eletronuclear, nomeadamente a China, a Coreia do Sul, os EUA, a Índia, o Japão e a Rússia. No seio da UE, a situação é muito diversa: a Bulgária, a França, a Eslováquia e a Finlândia decidiram construir novos reatores nucleares; vários países reabriram o debate sobre o possibilidade de prolongar a exploração das centrais existentes ou de as substituir [designadamente, os Países Baixos, a Polônia, a Suécia, a Lituânia (projeto "Países bálticos") e o Reino Unido]; por último, a Bélgica, a Alemanha e a Espanha assumiram o compromisso de abandonarem progressivamente ou a limitar a energia nuclear. Desde 1997, foram notificados à Comissão 19 projetos de investimento ${ }^{36}$.

\subsection{Origem}

A primeira grande realização da Europa supranacional consistiu na instauração da Comunidade Europeia do Carvão e do Aço (CECA), que iniciou suas atividades em Julho de 1952. Pela primeira vez, os seis Estados-Membros desta organização renunciaram, num domínio restrito, é certo a uma parte da sua soberania em prol da Comunidade.

Em breve período, porém, se definiriam os limites desta primeira iniciativa de integração, com o malogro da Comunidade Europeia da Defesa (CED), em 1954. Em uma altura em que se poderia temer que o esforço empreendido pela CECA não tivesse qualquer continuidade, a Conferência de Messina de Junho de 1955 procurou relançar o processo europeu, sendo seguida de uma série de outras reuniões de Ministros e peritos. No início de 1956, foi instituído um Comitê preparatório incumbido de elaborar um relatório 
sobre a criação de um mercado comum europeu. Este Comitê estava sediado em Bruxelas e era presidido por P.H. Spaak, o então Ministro dos Negócios Estrangeiros belga. Em Abril de 1956, o comitê apresentou dois projetos, que correspondiam às duas opções decididas pelos Estados:

- A criação de um mercado comum generalizado;

- A criação de uma comunidade da energia atômica.

Foi em Roma que foram assinados, em Março de 1957, os mais importantes e conhecidos Tratados da UE os famosos Tratados de Roma.

O primeiro instituiu a Comunidade Econômica Europeia (CEE) e o segundo a Comunidade Europeia da Energia Atômica, mais conhecida por Euratom.

Uma vez que as ratificações nos diversos países não levantaram problemas, os dois tratados entraram em vigor em um de Janeiro de $1958^{37}$.

\subsection{Objetivos}

Para lutar contra a carência generalizada de energia tradicional dos anos 50, os seis Estados fundadores (Alemanha, Bélgica, França, Itália, Luxemburgo e Países Baixos) procuraram na energia nuclear um meio para alcançar a independência energética. Como o custo do investimento nessa energia excedia as possibilidades de Estados isolados, os Estados fundadores uniram-se para constituir a Euratom.

O Tratado Euratom constitui a base jurídica para o quadro regulamentar que fixa obrigações e competências desenvolvidas no domínio da energia nuclear, particularmente em matéria de investigação bem como do controle da segurança e da seguridade.

Em termos gerais, o Tratado Euratom tinha por objetivo contribuir para a criação e o crescimento da indústria nuclear europeia, a fim de que todos os EstadosMembros pudessem se beneficiar do desenvolvimento da energia atômica, e garantir a segurança do abastecimento. Paralelamente, o Tratado proporcionou um elevado nível de seguridade às populações e impediu o desvio, para fins militares, dos materiais nucleares utilizados sobretudo para fins civis. Importa salientar que a Euratom só tem competência no domínio da energia nuclear para fins civis e pacíficos.

Já no preâmbulo, aliás, as Partes signatárias declaravam:

“- Conscientes de que a energia nuclear constitui um recurso essencial para assegurar o desenvolvimento e a renovação da produção e permitir o progresso da causa da paz, (...); 
- Decididos a criar as condições para o desenvolvimento de uma poderosa indústria nuclear, fonte de vastos recursos energéticos e de modernização das técnicas, contribuindo, através de outras aplicações, para o bem-estar dos seus povos;

- Preocupados em estabelecer as condições de segurança necessárias à eliminação dos perigos que possam advir para a vida e saúde das populações;

- Desejosos de associar outros países à sua causa e de cooperar com as organizações internacionais ligadas ao desenvolvimento pacífico da energia atômica, ..." ${ }^{37}$.

\section{3 Âmbito de aplicação}

O Tratado Euratom tem por objetivo a exploração conjunta das indústrias nucleares dos Estados-Membros. Neste contexto, só é aplicável a certas entidades (os Estados-Membros, as pessoas singulares e as empresas ou instituições de direito público ou privado) que exercem a totalidade ou uma parte das suas atividades num domínio abrangido pelo Tratado, especificadamente, os materiais cindíveis especiais, as matériasprimas e os minérios dos quais são extraídas as matérias-primas ${ }^{37}$.

\subsection{Regime jurídico}

O Tratado Euratom constitui legislação autônoma que confere amplas competências à Comunidade. A estrutura institucional do Tratado Euratom é, em linhas gerais, análoga à do Tratado CEE e assentada no mesmo "triângulo institucional" (Conselho, Comissão e Parlamento Europeu). Por conseguinte, a realização das funções atribuídas à Comunidade é assegurada não só pelo Parlamento Europeu, pela Comissão e pelo Conselho, como também pelo Tribunal de Justiça e pelo Tribunal de Contas. Cada instituição atua dentro dos limites das atribuições que lhe são conferidas pelo Tratado. $\mathrm{O}$ Conselho e a Comissão são assistidos pelo Comitê Econômico e Social, que exerce funções consultivas.

As instituições comunitárias são responsáveis pela aplicação do Tratado e pelos dois organismos próprios da Euratom: a Agência de Abastecimento (que visa assegurar um abastecimento regular e equitativo de minérios, matérias-primas e materiais cindíveis especiais na UE) e o Serviço de Salvaguardas nucleares (que efetua controles contábeis e materiais em todas as instalações nucleares da Comunidade).

Embora não atribua à Comissão competências específicas e exclusivas em determinados domínios, o Tratado Euratom continua constituindo um valor ampliado para os seus membros. Com efeito, com base nesse Tratado, a Comissão adotou um conjunto de recomendações e de decisões que, embora não sejam vinculativas, criam normas européias. 
Além disso, importa sublinhar que as demais políticas comunitárias, como a do ambiente e da investigação, também têm um impacto considerável no setor nuclear.

$\mathrm{O}$ valor ampliado da Euratom e da UE torna-se particularmente evidente no contexto de ampliação. Graças à Euratom, a UE é dotada de uma abordagem comunitária harmonizada em matéria de energia nuclear, que passa a ser aplicável aos países candidatos. As ampliações da UE a Leste colocam a tônica no setor nuclear e, em especial, nas questões relacionadas com a seguridade. Com efeito, a nuclear constitui uma importante fonte de energia para muitos países da Europa do Leste (candidatos ou novos membros da UE). Em contrapartida, o nível de segurança das suas centrais nucleares e de proteção das populações e dos trabalhadores nem sempre é suficiente. Neste contexto, a fim de melhorar essa situação, a Comissão prestou-lhes apoio através do Programa de ajuda comunitária aos países da Europa Central e Oriental (PHARE) que constitui o principal instrumento financeiro da estratégia de pré-adesão para os países da Europa Central e Oriental, candidatos à adesão à UE. No seguimento do colapso da União Soviética, muitos dos novos Estados independentes também se debatem com problemas semelhantes e, nesse caso, a Comissão também lhes presta assistência.

Por outro lado, outros temas ligados à energia nuclear foram ganhando importância ao longo dos anos, como o da segurança operacional das instalações nucleares, o armazenamento de resíduos radioativos e a não proliferação nuclear (salvaguardas nucleares). Embora essas matérias sejam da competência dos EstadosMembros, verifica-se certo nível de harmonização em nível internacional, graças ao conjunto de tratados, convenções e iniciativas que foram progressivamente estabelecendo um regime internacional para regulação de algumas atividades-chave do setor nuclear (Convenção sobre a Seguridade) $^{38}$.

\subsection{Estrutura}

O Tratado Euratom inclui 234 artigos, divididos em seis Títulos precedidos de um preâmbulo. O número de artigos foi reduzido para 177 desde a assinatura, em dezembro de 2007, do Tratado de Lisboa, Tratado que altera o Tratado da UE (Tratado UE), e o Tratado que institui a Comunidade Européia (Tratado CE)

- O Título I determina as oito missões que o Tratado atribui à Comunidade.

- O Título II define as disposições que favorecem o progresso no domínio da energia nuclear (o desenvolvimento da investigação, a difusão dos conhecimentos, a proteção sanitária, os investimentos, as empresas 
comuns, o abastecimento, o controle da segurança, o regime de propriedade, o mercado comum nuclear e as relações externas).

- O Título III é consagrado às instituições da Comunidade e às disposições financeiras gerais. Estas disposições foram adaptadas em conformidade com o Tratado de Lisboa que altera o Tratado UE e o Tratado CE, assinado em Dezembro de 2007.

- O Título IV prevê as disposições financeiras específicas.

- Os Títulos V e VI definem, respectivamente, as disposições gerais e as disposições relativas ao período inicial (criação das instituições, primeiras disposições de aplicação e disposições transitórias).

Além disso, o Tratado inclui cinco Anexos pertencentes ao âmbito da investigação referente à energia nuclear referido no artigo quarto do Tratado, aos setores industriais referidos no artigo $41 .^{\circ}$ do Tratado, às vantagens susceptíveis de serem concedidas às empresas comuns de acordo com o artigo $48 .^{\circ}$ do Tratado, à lista dos bens e produtos abrangidos pelas disposições do Capítulo nove, relativo ao mercado comum nuclear e ao programa inicial de investigação e ensino referido no artigo $215 .^{\circ}$ do Tratado.

Por último, foram igualmente anexados ao Tratado dois Protocolos. Trata-se do Protocolo relativo à aplicação do Tratado que institui a Comunidade Europeia da Energia Atômica às partes não europeias do Reino dos Países Baixos e do Protocolo relativo ao estatuto do Tribunal de Justiça da Comunidade Europeia da Energia Atômica ${ }^{38}$.

\subsection{Missões}

De acordo com o Tratado, as missões específicas da Euratom são as seguintes:

1. Desenvolver a investigação e assegurar a difusão dos conhecimentos técnicos.

A Comissão convida os Estados-Membros, pessoas e empresas a comunicarlhe os respectivos programas relativos à investigação nuclear. A Comissão deve publicar periodicamente uma lista dos setores da investigação nuclear que considera insuficientemente estudados e criar um Centro Comum de Investigação Nuclear. O Centro Comum de Investigação (CCR) passa a desempenhar um papel fundamental no domínio da investigação nuclear comunitária e em áreas como a do ambiente ou a da segurança alimentar.

Os Estados-Membros, pessoas e empresas podem, mediante pedido apresentado à Comissão, beneficiar-se de licenças não exclusivas sobre patentes, títulos de 
proteção provisória, modelos de utilidade ou pedidos de patente que sejam da propriedade da Comunidade.

2. Estabelecer normas de segurança uniformes destinadas à proteção sanitária da população e dos trabalhadores e zelar pela sua aplicação.

Todos os Estados-Membros devem estabelecer disposições legislativas, regulamentares e administrativas adequadas para assegurar a observância das normas básicas fixadas no Tratado, incluindo medidas relativas ao ensino, à educação e à formação profissional. A legislação adotada abrange ainda as aplicações médicas, a investigação, os níveis máximos admissíveis de contaminação radioativa dos generos alimentícios e as medidas de proteção a serem tomadas em caso de emergência radiológica. Cada Estado-Membro deve fornecer à Comissão os dados gerais relativos a todos os projetos de descarga de efluentes radioativos. Paralelamente, é necessário o parecer favorável da Comissão se essas experiências puderem afetar os territórios de outros Estados-Membros.

3. Facilitar os investimentos e assegurar, designadamente encorajando as iniciativas das empresas, a criação das instalações essenciais ao desenvolvimento da energia nuclear na UE.

A Comissão procede periodicamente à publicação de programas de caráter indicativo (PINC) que incidem, principalmente, nos objetivos de produção de energia nuclear e nos investimentos necessários à sua realização. As pessoas e empresas ligadas aos setores industriais enumerados no Anexo II do Tratado devem comunicar à Comissão os seus projetos de investimento.

4. Zelar pelo abastecimento regular e equitativo de todos os utilizadores da Comunidade em minérios e combustíveis nucleares

$\mathrm{O}$ abastecimento em minérios, matérias-primas e materiais cindíveis especiais é assegurado de acordo com o princípio da igualdade de acesso aos recursos e mediante a adoção de uma política comum de abastecimento. Neste contexto, o Tratado:

- proíbe todas as práticas que se destinem a assegurar uma posição privilegiada de certos utilizadores;

- constitui uma Agência que, além do direito de opção sobre os minérios, matérias-primas e materiais cindíveis especiais produzidos nos territórios dos EstadosMembros, beneficia ainda do direito exclusivo de celebrar contratos de fornecimento de minérios, matérias-primas ou materiais cindíveis especiais, quer provenham do interior ou do exterior da Comunidade. 
A Agência de Abastecimento da Euratom é dotada de personalidade jurídica e de autonomia financeira, sendo colocada sob a alçada da Comissão, que formula as suas orientações e dispõe de um direito de veto sobre as suas decisões.

Os Estados-Membros devem apresentar anualmente à Comissão um relatório sobre o desenvolvimento da prospecção e da produção, bem como sobre as reservas previsíveis e os investimentos realizados ou previstos no setor mineiro nos respectivos territórios.

5. Garantir que os materiais nucleares civis não sejam desviados para fins diferentes daqueles a que se destinam.

O Tratado Euratom estabeleceu um sistema de controle muito completo e rigoroso de forma a garantir que os materiais nucleares civis não sejam desviados da finalidade civil declarada pelos Estados-Membros. A UE dispõe de competência exclusiva nesta área, que exerce através de um corpo de 300 inspetores responsáveis pela aplicação das salvaguardas nucleares Euratom na UE.

No território dos Estados-Membros, a Comissão deve certificar-se de que:

- os minérios, matérias-primas e materiais cindíveis especiais não sejam desviados da utilização declarada pelos seus utilizadores.

- são respeitadas as disposições relativas ao abastecimento, bem como os compromissos especiais destinados a assegurar o acesso aos melhores meios técnicos, através de um mercado comum dos materiais, equipamentos, entre outros.

A Comissão pode enviar inspetores para os territórios dos Estados-Membros. Esses inspetores deverão ter acesso, em qualquer momento, a todos os locais, informações pessoas que, por motivos profissionais, se ocupem de materiais, equipamentos ou instalações sujeitos a salvaguardas nucleares.

As salvaguardas nucleares Euratom articulam-se com as garantias exercidas pela AIEA no âmbito de acordos tripartidos concluídos pelos Estados-Membros, a Comunidade e a AIEA.

A AIEA é uma organização autônoma com sede em Viena na Áustria, que coopera com a ONU. Esta agência destina-se, por um lado, a promover a utilização da energia nuclear para fins pacíficos e, por outro, a zelar para que o apoio concedido não seja utilizado para fins militares.

Em caso de infração às obrigações, a Comissão pode impor sanções às pessoas ou empresas responsáveis. Trata-se de sanções que vão da simples advertência até à retirada total ou parcial das matérias-primas ou materiais cindíveis especiais, passando pela 
retirada de vantagens especiais (como a assistência financeira ou o apoio técnico) ou ainda pela colocação da empresa sob a administração de uma pessoa ou de uma entidade colegial.

6. Exercer o direito de propriedade que lhe é reconhecido sobre os materiais cindíveis especiais.

7. Promover o progresso através da utilização pacífica da energia nuclear em colaboração com os países terceiros e as organizações internacionais.

A Comissão negocia e conclui acordos que estruturam a cooperação nuclear com os países terceiros. A conclusão de tais acordos também está subordinada à aprovação do Conselho. Os Estados-Membros, por seu lado, devem comunicar à Comissão os seus projetos de acordos ou convenções com países terceiros, organizações internacionais ou nacionais de Estados terceiros. Atualmente, existem acordos Euratom com um grande número de países, designadamente os EUA, a Austrália e o Canadá.

\section{Constituir Empresas Comuns}

Estas empresas são constituídas tendo em vista um projeto específico de primordial importância para o desenvolvimento da indústria nuclear europeia. A título de exemplo, citamos o Joint European Torus (JET) no domínio da fusão nuclear, empresa dissolvida no ano 2000 cujas atividades prosseguem, no entanto, sob a égide do "European Fusion Development Agreement" ( EFDA) ${ }^{38}$.

\subsection{Futuro do Tratado Euratom}

Contrariamente ao Tratado CE, o Tratado Euratom nunca sofreu grandes alterações e mantém-se em vigor. A Comunidade Europeia da Energia Atômica não foi fundida com a União, mantendo, por conseguinte, uma personalidade jurídica distinta, embora partilhe as mesmas instituições. O Tratado de Lisboa que altera os Tratados UE e CE, assinado em dezembro de 2007, modifica certas disposições do Tratado Euratom através do seu "Protocolo (n. ${ }^{\circ}$ 2) que altera o Tratado que institui a Comunidade Europeia da Energia Atômica". Essas alterações limitam-se a adaptações às novas regras estabelecidas pelo Tratado de Lisboa, nomeadamente nos domínios institucional e financeiro.

Em março de 2007, a Comissão procedeu a um balanço e avaliou as perspectivas relativas ao Tratado Euratom. O balanço é amplamente positivo, em especial nos domínios da investigação, da proteção da saúde, do controle do uso pacífico dos materiais nucleares e das relações internacionais. A necessidade de garantir a segurança do abastecimento de energia e as preocupações ligadas às alterações climáticas vêm reforçar 
ainda mais o interesse pela energia nuclear. No futuro, a aplicação do Tratado Euratom deve continuar a incidir na segurança e no controle dos materiais nucleares. A Euratom deverá continuar a contribuir para enquadrar o desenvolvimento da indústria nuclear e para assegurar o respeito de normas rigorosas em matéria de proteção contra as radiações, de segurança e de controle $\mathrm{e}^{38}$.

\subsection{Gestão dos riscos ligados à energia nuclear}

A percepção do setor nuclear pela opinião pública é um elemento essencial para a aceitabilidade e o futuro da produção eletronuclear. O que implica que a população tenha acesso a informações confiáveis e possa participar num processo de decisão transparente. A UE já está fortemente empenhada na gestão dos riscos ligados à energia nuclear e prevê um maior reforço da sua ação.

A intervenção da UE pretende igualmente garantir a seguridade nuclear: a UE garante a aplicação das convenções internacionais na matéria e contribui financeiramente para a melhoria da seguridade nuclear tanto em nível das suas fronteiras, especificamente na sequência das ampliações de 2004 e 2007, como dos países terceiros.

O descomissionamento das instalações é uma operação complexa e dispendiosa que deverá abranger cerca de um terço das centrais atualmente em atividade até 2025. Por conseguinte, é necessário dispor de recursos financeiros suficientes, eventualmente através de fundos distintos. A Comissão sublinha que os custos reais do descomissionamento deve, no final, serem suportados pelos operadores.

Em matéria de rejeitos radioativos, trata-se na sua grande maioria de rejeitos de nível baixo e um período de vida curto, em relação aos quais são instituídas estratégias à escala industrial em quase todos os Estados-Membros dotados de instalações eletronucleares. A retirada dos rejeitos radioativos de nível alto e de vida longa é determinada por fatores sociais, em especial a escolha dos sítios de depósito definitivo e a aceitação desta escolha pela população. A investigação coloca, além disso, a tônica nas técnicas de redução do volume ou da duração da vida dos rejeitos radioativos ou dos componentes de vida longa.

Ainda hoje, os rejeitos radioativos são depositados em instalações de armazenamento provisórios e não existem em nenhum Estado-Membro instalações de armazenamento definitivo de rejeitos radioativos de nível alto e de vida longa procedentes da utilização da energia nuclear ${ }^{38}$. 


\subsection{Proteção contra as radiações}

Em matéria de proteção contra as radiações, a Comissão constata que a exposição dos trabalhadores da indústria nuclear e as descargas radioativas procedentes das indústrias nucleares diminuíram fortemente, enquanto a exposição ligada ao domínio médico ou a fontes naturais de radiação poderia ser ainda mais reduzida. Foram também registrados progressos importantes na reação a situações de emergência, no intercâmbio de informações, nos controles alimentares e na prevenção da perda ou do desvio das fontes radioativas.

O capítulo "a proteção sanitária" do Tratado Euratom deu origem a um considerável corpus de legislação comunitária para a proteção sanitária dos trabalhadores e do público em geral.

As normas de segurança de base foram atualizadas em 1996 e completadas pelas Diretivas 96/29 e 97/43/Euratom relativas à proteção da saúde das pessoas contra os perigos resultantes de radiações ionizantes em exposições radiológicas médicas (para tratamento e diagnóstico). A utilização de fontes de radiação em medicina torna-se cada vez mais importante, com as novas tecnologias aumentando constantemente as doses para os pacientes. Poderiam conseguir-se grandes reduções da exposição da população tanto no domínio médico como em relação às fontes de radiação natural (Radônio na habitação ou indústrias que processam minérios com elevado teor de Urânio ou Tório).

Em contrapartida, a exposição dos trabalhadores na indústria nuclear tem mostrado uma acentuada tendência para diminuir, impulsionada pela exigência regulamentar de todas as doses serem tão pequenas quanto razoavelmente exeqüível. Também as descargas de efluentes radioativos (gasosos e líquidos) das indústrias nucleares, em particular de fábricas de reprocessamento, têm apresentado uma drástica diminuição nas últimas décadas.

A investigação efetuada ao abrigo do programa-quadro comunitário tem aprofundado a compreensão dos efeitos biológicos das radiações e confirmado a abordagem cautelar adotada internacionalmente. Embora, em funcionamento normal, as instalações nucleares possam, portanto, ser consideradas verdadeiramente seguras, não se ignora a possibilidade de um acidente grave: a legislação comunitária adotada na sequência do acidente de Chernobyl tem proporcionado importantes avanços em matéria de preparação para emergências, intercâmbio de informações e controle alimentar. 
Estão também sendo apoiadas pela Comissão medidas para reforçar o controle das fontes radioativas a fim de evitar a sua utilização abusiva ou perda ou de eliminar os riscos de exposição do público em resultado de terrorismo radiológico ou nuclear.

O Tratado Euratom (artigos $31 .^{\circ}$ e $32 .^{\circ}$ ) fornece o fundamento jurídico para iniciativas comunitárias no domínio da seguridade. Esta base jurídica foi reafirmada pelo Tribunal de Justiça em dezembro de 2002. Nos termos do artigo 35. ${ }^{\circ}$ do Tratado, "os Estados-Membros providenciarão pela criação das instalações necessárias para efetuar o controle permanente dos níveis de radioatividade liberados no ambiente e pelo controle do cumprimento das normas de segurança de base".

O artigo 37. ${ }^{\circ}$ do Tratado impõe aos Estados-Membros a obrigação de fornecer à Comissão os dados gerais de todos os projetos de descarga de efluentes radioativos, seja qual for a sua forma, que permitam determinar se a realização de tais projetos é susceptível de afetar o ambiente de outro Estado-Membro.

As salvaguardas nucleares da Euratom, tal como previsto nos artigos $77 .^{\circ}$ a 79. ${ }^{\circ}$, e os poderes ampliados conferidos à Comissão nos termos dos $\operatorname{artigos~} 81 .^{\circ}$ a $83 .^{\circ}$ são fundamentais para a utilização segura dos materiais nucleares e obrigatórias para a utilização e o desenvolvimento contínuos da indústria nuclear ${ }^{38}$.

\subsection{Investigação europeia no domínio nuclear}

Atualmente, a investigação europeia no domínio nuclear é efetuada no âmbito do Sétimo Programa-Quadro Euratom. É neste quadro que são abordadas as principais preocupações políticas e sociais, como a gestão dos rejeitos radioativos e a segurança dos atuais reatores, ao lado de outras questões energéticas de mais longo prazo, como os ciclo do combustivel nuclear e reatores inovadores. O ensino e formação, juntamente com o apoio às infra-estruturais de investigação, são importantes domínios transversais que recebem apoio. Essas atividades de investigação ajudam a estruturar e catalisar os programas de investigação e desenvolvimento nos vários Estados-Membros, contribuindo para o estabelecimento do Espaço Europeu da Investigação (EEI) no domínio da cisão nuclear. O EEI foi lançado pela Comissão Europeia em 2000 para assegurar uma coordenação mais estreita das atividades de investigação e melhorar a convergência das políticas em nível nacional e comunitário. Faz parte integrante da Agenda de Lisboa para a construção de uma Europa mais dinâmica e competitiva. Esta estratégia de investigação comunitária iniciada no Sexto Programa-Quadro Euratom será consolidada durante o Sétimo Programa-Quadro Euratom, com o estabelecimento de plataformas tecnológicas que visam uma plena implementação do EEI no domínio da ciência e tecnologia nuclear. 
A manutenção das competências em matéria de proteção radiológica e de tecnologia nuclear tanto na indústria nuclear como na medicina é fundamental para a UE, tal como o são segurança e a proteção do ambiente, graças aos esforços desenvolvidos no domínio da cisão nuclear e das tecnologias inovadoras de reatores. Importa manter este esforço, em colaboração com iniciativas globais como o Mecanismo a favor das Pequenas e Medias Empresas Inovadoras e de Elevado Crescimento (MIC), a atual investigação Euratom nesse domínio estuda principalmente a viabilidade dos sistemas inovadores e do ciclo de combustível nuclear propostos. Contribui assim para o debate sobre o futuro abastecimento energético e para a tomada de decisões estratégicas sobre sistemas e vetores energéticos ${ }^{38}$.

\subsection{Energia nuclear e competitividade}

A energia nuclear já contribui significativamente para a matriz energética da UE, reduzindo assim a preocupação com potenciais faltas de segurança no fornecimento de eletricidade. O custo da produção de eletricidade nuclear mostra uma sensibilidade limitada à flutuação dos custos de importação das fontes de energia de base (Urânio) e, tal como o sublinha a Agência Internacional da Energia (AIE), sediada em Paris, França que atua como a orientadora política para a energia para 26 países membros, trata-se de uma opção de produção economicamente viável, desde que sejam devidamente tomadas em conta as preocupações ambientais e sociais.

Essencialmente isenta de emissões de $\mathrm{CO} 2$, a energia nuclear dá uma importante contribuição para a atenuação das alterações climáticas globais resultantes das emissões de gases de efeito estufa.

Cabe aos Estados-Membros decidir se utilizarão ou não à energia nuclear. Para os países da UE que optem por continuar ou começar a recorrer à produção de eletricidade nuclear, os Governos dos Estados-Membros terão de tomar as decisões necessárias. Um número significativo de centrais nucleares deverá, efetivamente, ser encerrado nos próximos 20 anos.

Será necessário construir novas centrais ou prolongar a atual vida útil dos reatores existentes se os Estados-Membros optarem por manter a atual porcentagem da energia nuclear na matriz energética global.

A procura de eletricidade de origem nuclear está aumentando em escala mundial. A UE assume um papel de liderança industrial neste domínio. Isto cria oportunidades comerciais para as empresas européias e vantagens potenciais para a economia da UE, contribuindo assim para a Agenda de Lisboa. Por essa razão, é necessário 
um ambiente de investimento e um quadro legislativo pelo menos adequados a fim de desenvolver eventualmente esse potencial.

A Comunidade deve aumentar a sua cooperação com organismos internacionais, como a AIEA e a AIE, e manter-se coerente com todas as obrigações internacionais, nomeadamente em termos de não-proliferação dos materiais nucleares e de tecnologia nuclear, proteção e da segurança dos trabalhadores e da população em geral, seguridade e ambiente.

A Comunidade considera a seguridade como critério essencial no processo de tomada de decisões dos Estados-Membros quanto à eventual continuação da utilização da energia nuclear. Para os Estados-Membros que optem por seguir o caminho nuclear, a aceitação do público será também um fator importante. A Comunidade tem um importante papel a desempenhar para garantir que a indústria nuclear se desenvolva de forma segura. Nesse contexto, a Comissão considera prioritário que a Comunidade adote um quadro jurídico para a seguridade, facilitando a harmonização e o respeito das normas internacionalmente aceitas e garantindo a disponibilidade de fundos adequados para o descomissionamento das centrais nucleares no final da sua vida útil, e planos para a gestão dos rejeitos radioativos.

Tal como a restante política energética da UE, o desenvolvimento da energia nuclear deverá reger-se pelo princípio da subsidiariedade, basear-se na competitividade tecnológica do setor e ser uma componente da matriz energética. Há claramente impactos para toda a UE das decisões adotadas pelos Estados-Membros no domínio da energia nuclear, embora pertença a cada Estado-Membro a escolha da sua matriz energética nacional. Para dar uma imagem atualizada da situação na UE, a Comissão irá - em conformidade com o artigo $400^{\circ}$ do Tratado Euratom - aumentar a freqüência de publicação dos programas indicativos nucleares ${ }^{38}$.

A Comissão propõe que as discussões incidam no futuro, particularmente, no reconhecimento de níveis de referência comuns, na criação de um grupo de elevado nível sobre segurança e gestão de rejeitos radioativos, na instauração de planos nacionais de gestão de rejeitos radioativos, na harmonização das abordagens relativas aos fundos de desmantelamento, bem como na elaboração de um regime pactuado de responsabilidade e de mecanismos financeiros no caso de danos provocados por um acidente nuclear. 


\section{DISCUSSÃO}

Em que pesem as especificidades políticas de cada momento da história vivida pelo Brasil, a de uma ditadura militar ou de um governo de transição para a democracia, em ambos, o domínio do conhecimento científico e tecnológico e a percepção política de que esse conhecimento é fundamental para o desenvolvimento sustentável do país, entendido como fonte de poder estrutural, foi convertido em chave para a inserção internacional brasileira no setor de energia nuclear.

Do ponto de vista político, a tecnologia nuclear também convida ao debate e expressa a atualidade do tema e sob essa ótica é que serão alicerçadas as considerações feitas na presente discussão.

Contextualizando os pontos fortes e os pontos fracos da legislação nacional, a partir de uma comparação com a adotada pela UE, referente às atividades nucleares, podemos fazer as seguintes considerações:

A política energética comunitária considera a utilização da energia nuclear em sua matriz energética como forma de diversificar e garantir seu abastecimento.

O Brasil não só utiliza a energia nuclear para compor parte de sua matriz energética como forma de diversificar e garantir seu abastecimento, mas também a emprega em larga escala em aplicações de tecnologias nucleares, em áreas como indústria, saúde e agricultura para melhoria da qualidade de vida da população e conservação do meio ambiente.

No entanto, quanto aos possíveis impactos positivos e negativos do fomento e uso dessa fonte, e a decisão de sua utilização, cabe aos Estados-Membros, sendo essencialmente uma questão de opção a ser tomada em face das vantagens e desvantagens perante as outras fontes atualmente empregadas.

Em nosso país, por tratar-se de um monopólio estatal, cabe quase que exclusivamente ao Estado decidir sobre a sua utilização, salvo as permissões concedidas para uso pela iniciativa privada.

Feita a opção pela energia nuclear, no âmbito comunitário, esta será regulada pelo instrumento legal específico, denominado Tratado Euratom, que exige, entre outras medidas a serem observadas, as de proteção à saúde humana e às populações, além do controle da radiação no meio ambiente.

No Brasil, o principal órgão regulador e normativo da área nuclear é a CNEN, com determinações e atribuições semelhantes às indicadas pela Euratom. 
Inicialmente destinado a coordenar os programas de investigação dos EstadosMembros com vista à utilização pacífica da energia nuclear, o Tratado Euratom contribui, hoje em dia, para a partilha do conhecimento das infra-estruturas e do financiamento da energia nuclear, garantindo a segurança do abastecimento da energia atômica em um quadro de controle centralizado para toda a UE.

Ao compararmos a legislação brasileira na área nuclear com a praticada na UE, não encontramos similaridade com relação às matérias compreendidas no processo legislativo, que variam seus trâmites, da iniciativa à promulgação. Enquanto a base jurídica da legislação nacional tem sua origem na Constituição Federal, a da UE é alicerçada em um Tratado infraconstitucional.

No entanto, as normas legais aplicadas em ambas, decorrentes desses ordenamentos jurídicos, encontram semelhanças e resultados positivos na seguridade, principalmente em matéria do quadro regulamentar e gestão da segurança das centrais nucleares (na concepção, na exploração, na manutenção, e no descomissionamento), segurança do transporte, do tratamento e eliminação do combustivel nuclear irradiado e dos rejeitos radioativos, proteção contra as radiações ionizantes emitidas pelos materiais radioativos e prevenção e reação em caso de acidentes. Pois ambos se detiveram a assumir as recomendações internacionais da AIEA que, por sua vez, se baseiam naquelas da CIPR.

Comprovando tal afirmação, temos que o Tratado Euratom constitui legislação autônoma que confere amplas competências à Comunidade e as instituições comunitárias que são responsáveis pela aplicação do Tratado e pelos dois organismos próprios da Euratom, a Agência de Abastecimento e o Serviço de Salvaguardas nucleares.

As salvaguardas nucleares da Euratom articulam-se com as garantias exercidas pela AIEA, no âmbito de acordos tripartidos, concluídos pelos EstadosMembros, a Comunidade e a AIEA.

No Brasil, o processo de integração nuclear, no âmbito do MERCOSUL, dá-se com a Declaração de Fiscalização Mútua, firmada em 28 de novembro de 1990, marcando o inicio de uma etapa de cooperação bilateral nuclear entre Brasil e Argentina, ao criar o Sistema Comum de Contabilidade e Controle (SCCC), estabelecendo o cumprimento das seguintes atividades: 1) intercâmbio das listas descritivas de todas as instalações nucleares e das declarações dos inventários dos materiais atômicos existentes em cada país; 2) realização de inspeções recíprocas nos sistemas centralizados dos registros; 3) apresentação dos sistemas de registros e relatórios do SCCC à AIEA; 4) agenciamento da entrada em vigor do Tratado de Tlatelolco e atualização de seus termos. 
A viabilização jurídica da Declaração de Fiscalização Mútua foi formalizada através de um amplo acordo: o Acordo para o Uso Exclusivamente Pacífico da Energia Nuclear, firmado em 18 de julho de 1991, em Guadalajara, México, criando a Agência Brasileiro - Argentina de Contabilidade e Controle de Materiais Nucleares (ABACC), com personalidade jurídica e sede no Rio de Janeiro. A esse acordo, em 20 de agosto de 1991, foi firmado um Protocolo Adicional, estabelecendo privilégios e imunidades aos funcionários e inspetores em missão ou serviços da ABACC. Em síntese: o Acordo de 1991, concede às partes o direito inalienável ao desenvolvimento da pesquisa, produção e utilização da energia nuclear com fins pacíficos, preservando os segredos industriais, tecnológicos e comerciais de ambos os países.

E ainda, com base na Euratom, a Comissão adotou um conjunto de recomendações e de decisões que, embora não sejam vinculativas, criaram normas européias, que levaram a uma abordagem comunitária concorde em matéria de energia nuclear.

Também, ao longo dos anos na UE, temas como o da segurança operacional das instalações nucleares, o armazenamento de rejeitos radioativos e a não proliferação nuclear (salvaguardas nucleares), foram ganhando importância, graças ao conjunto de tratados, convenções e iniciativas que foram progressivamente estabelecendo um regime internacional para regulação de algumas atividades-chave do setor nuclear. Fontes preciosas de informação a serem utilizadas pelo Brasil em suas ações voltadas ao desenvolvimento da área nuclear.

A Comissão negociou e concluiu acordos que estruturaram a cooperação nuclear com os países terceiros. Atualmente, existem acordos Euratom com um grande número de países, dentre os quais podemos ressaltar os EUA, Austrália, Canadá e támbem com o Brasil. Podemos citar como exemplo, o acordo firmado entre a França e o Brasil para o desenvolvimento e construção de submarinos movidos à energia nuclear.

A UE garante a aplicação das convenções internacionais para assegurar a seguridade e contribui financeiramente para a melhoria dessa matéria, tanto no nível das suas fronteiras, especificamente na sequência das ampliações de 2004 e 2007, como dos países terceiros.

Com relação ao PNB, que se encontra em vigor, esse, apresenta um perfil de atuação, mais teórico e voltado para a orientação de diretrizes a serem seguidas para o desenvolvimento e utilização da energia nuclear, do que para ações reais de produção e execução de projetos para o seu desenvolvimento. No entanto, encontra-se em fase de 
aprovação oficial pelo governo, um novo PNB, preparado por um grupo interministerial, estruturado para estabelecer um planejamento para o setor até 2022, já contando esse Plano com o respaldo do Programa Nacional de Energia (PNE).

Na estruturação do novo PNB, o grupo de estudo englobou todas as áreas do setor, reunidas em quatro grandes linhas: geração nucleoelétrica, produção de combustível nuclear, aplicações da área nuclear e desenvolvimento tecnológico.

Foram então delineadas orientações estratégicas básicas para nortear as ações traçadas. Em primeiro lugar, a geração nuclear permanecerá como um dos componentes da matriz energética brasileira com papel crescente no atendimento das necessidades de energia do país. Como parte desta política, deverão ser exploradas as possibilidades de aplicação de reatores de pequena e média potência para a geração de energia elétrica, além de dessalinização da água e propulsão naval.

Estamos totalmente de acordo com esse direcionamento, uma vez que o fornecimento de energia é primordial para o desenvolvimento da nação e, diante das dimensões continentais do país, uma distribuição de reatores de pequena e média potência contribuirão com melhor eficácia para geração de energia e dessalinização da água.

Uma distribuição desses reatores em pontos estratégicos do país, também contribuirão para um desenvolvimento sustentável da região, agregando valores produtivos e uma melhor redistribuição da população, diante das melhorias que estas instalações acabam por introduzir nos locais, por força de lei.

Além disso, o Urânio foi considerado um combustível fundamental para o país alcançar a independência energética e será cada vez mais valorizado. A grande disponibilidade do minério em solo nacional poderá permitir a exportação de produtos do ciclo do combustivel nuclear, desde que seja preservada a garantia do atendimento às necessidades nacionais a longo prazo e que as condições políticas e econômico-financeiras assim o recomendem.

O Brasil detém a sexta maior reserva mundial de Urânio, minério que, depois de enriquecido, torna-se o combustível das centrais nucleares. Só há três países no mundo que têm reservas e tecnologia para produzir este combustível: EUA, Rússia e o Brasil. Com esse cenário não se pode desprezar essa fonte de energia.

A quebra do monopólio neste setor, tambem irá contribuir para que a iniciativa privada tenha um maior interesse em investir na área nuclear, contribuindo com o desenvolvimento da nação, seguindo o exemplo da Petrobras e outras grandes empresas de sucesso na área energética nacional. 
As aplicações da radiação ionizante e das técnicas nucleares permanecerão sendo utilizadas no país e desempenharão um papel crescente no atendimento de necessidades nas áreas da saúde, indústria, agricultura e meio-ambiente, contribuindo para o desenvolvimento sustentável da sociedade brasileira. Por último, a execução do PNB não deverá implicar num aumento da dependência do país em relação a bens e serviços importados, no intuito de promover o desenvolvimento tecnológico independente.

Igualmente, estamos totalmente de acordo com essas diretrizes, uma vez que temos comprovada a importância das aplicações nucleares nas áreas supra mencionadas, com destaque para as da área médica, que tanto tem contribuido para uma melhoria da saúde e qualidade de vida da população e, que recentemente sofreu uma grave crise no setor da medicina nuclear, pela falta de material radioativo para exames, diante da pouca produção e dependência externa da matéria prima.

E suas diretrizes gerais se manteriam voltadas para fins pacíficos e não proliferação, proteção e segurança política segura dos rejeitos radiotaivos e formação e treinamento de recursos humanos para a área.

Em nossa opinião, a energia nuclear é uma fonte de energia "limpa", considerando que não emite gás poluente para a atmosfera, utiliza em sua construção um número reduzido de materiais (por $\mathrm{kWh}$ ) se comparada com a energia solar e eólica, produz pequena quantidade de rejeitos radioativos de alta atividade, e não contribui para o efeito estufa, pois não emite dióxido de carbono $(\mathrm{CO} 2)$, ao contrário do carvão, petróleo e gás; além de não necessitar de grandes reservatórios (com seus decorrentes problemas ambientais) das hidroelétricas. É uma alternativa viável para a maior parte dos países, para suprir a crescente demanda por energia ante a futura escassez dos combustíveis fósseis, sendo que a maior concentração de usinas nucleares encontra-se nas principais regiões consumidoras de energia do mundo.

Nesse contexto, as diretrizes gerais definidas pelo novo PNB, encontram total sinergia. Sua destinação é totalmente voltada para fins pacíficos e praticada com seguridade, no entanto, a falta de investimentos na área nos últimos anos, ocasionou reflexos no setor de pessoal e a evasão de profissionais qualificados vem ocorrendo, especialmente, pela procura por outras oportunidades de trabalho em órgãos públicos e privados e por motivo de aposentadoria, reduzindo a capacidade intelectual e dificultando o prosseguimento de algumas metas definidas e a manutenção de conquistas tecnológicas já alcançadas. 
Nesse aspecto, a formação e o treinamento de recursos humanos para reposição destes quadros são de grande importância, a carência da demanda de profissionais na área nuclear no Brasil é muito grande. Entendemos que, políticas de incentivo para a formação de engenheiros na área nuclear, são necessárias, com a criação de novos cursos de graduação e possibilidades de estágio e colocação profissional.

Com relação à Pós-graduação na área, sugerimos incentivar o intercâmbio dos alunos desse nível, com os de cursos similares em países terceiros detentores dessa tecnologia, para aprimorarem sua qualificação, uma vez que os cursos oferecidos no país são de ótima qualidade.

Quanto à política dos rejeitos radioativos, essa é tratada de forma diferente nos diversos países e continentes, sendo que a utilização da energia nuclear está em diferentes estágios em cada país, mas há uma semelhança que os une: a não aceitação pública quanto à segurança de se armazenar rejeitos radioativos.

O órgão federal que licencia, fiscaliza e normatiza as instalações nucleares radioativas brasileiras, a fim de que todo material radioativo não ofereça risco à população e ao meio ambiente, é a CNEN.

Todas as atividades que envolvem o uso de materiais radioativos geram, em alguma etapa do processo, resíduos denominados rejeitos radioativos.

A CNEN define rejeito radioativo como sendo "qualquer material resultante de atividades humanas que contenha radionuclídeos em quantidades superiores aos limites de isenção, especificados na Norma CNEN-NE-6.02 Licenciamento de Instalações Radiativas e para o qual a reutilização é imprópria ou não prevista". O termo "limite de isenção", aplicado aos rejeitos radioativos, pode ser compreendido como sendo o nível de atividade abaixo do qual a autoridade considera que os riscos correspondentes são insignificantes e não requerem controle legal.

Os rejeitos radioativos podem ser classificados por diversos critérios: requisitos de segurança para seu manuseio, estágio de desenvolvimento da indústria nuclear em um país, regulamentos e normas de transporte, características físico-químicas, concentração de material radioativo presente nos rejeitos, entre outros. Nessas classificações são comumente utilizados os termos "nível baixo", "nível médio" e "nível alto" e, embora os valores numéricos que diferenciam esses termos sejam distintos em diversos países, seguem os seguintes conceitos:

- rejeitos de nível baixo - não requerem blindagem para manuseio e transporte; 
- rejeitos de nível médio - requerem blindagem para manuseio e transporte e não são geradores de calor;

- rejeitos de nível alto - requerem blindagem e também resfriamento, uma vez que são geradores de calor.

$\mathrm{Na}$ prática, utiliza-se principalmente a classificação referente às características físicas e químicas e ao tipo de tratamento que o rejeito será submetido.

Os rejeitos radioativos podem ser ainda classificados de acordo com sua origem, em três principais grupos: rejeitos institucionais, rejeitos do ciclo do combustível e rejeitos de descomissionamento.

Atualmente empregam-se duas formas de se realizar a disposição final dos rejeitos radioativos: dispersão direta na biosfera, ou confinamento em repositórios. A aplicabilidade de cada uma destas opções depende do tipo e atividade dos radionuclídeos presentes no rejeito e também das características ambientais do meio receptor.

Existe consenso internacional de que as atividades de gerência de rejeitos radioativos devem ser conduzidas sob os princípios éticos de proteção das gerações presente e futura e de proteção ao meio ambiente. Há consenso, também, sobre a necessidade de estabelecimento de um marco legal, ou seja, um conjunto de leis e requisitos legais subsidiários, tais como normas e regulamentos, que dê as garantias necessárias para o desenvolvimento e financiamento daquelas atividades, como também que dê garantias da continuidade e manutenção das instituições e de suas responsabilidades pelo tempo que for necessário.

A AIEA estabelece a criação de um marco legal no país, como requisito básico que precisa ser satisfeito para assegurar que a gerência dos rejeitos radioativos seja realizada com segurança.

Atualmente, a CNEN possui quatro depósitos para armazenar os rejeitos radioativos: um definitivo em Goiânia exclusivo para os rejeitos provenientes do acidente com Césio-137; e três intermediários, situados em São Paulo, Belo Horizonte e Rio de Janeiro.

Nossa opinião com relação a este tema é de que, diante do resultado do PNB, em termos de escala ou demanda, não se justifica a construção, no momento, de um depósito final para rejeitos radioativos de nível alto no país, devendo manter-se esses rejeitos armazenados no local de origem. Para os rejeitos radioativos de nível baixo e médio deverão ser construídos novos depósitos intermediários, de acordo com a necessidade verificada em estudos a serem realizados pelo setor. Tanto para os atuais 
depósitos, como para os que serão construídos, é de suma importância que sempre seja observada a legislação e as ações de gestão internacional, e as decisões, na medida em que sejam aplicáveis a eles, tomadas pelas partes em outros convênios regionais pertinentes sobre meio ambiente que tratem de outros aspectos do manejo seguro e ambientalmente saudável dos rejeitos radioativos.

Aguardando a aprovação oficial, os responsáveis pela aplicação das políticas do PNB vigente, têm pautado suas ações, já buscando atingir os objetivos delineados pelo novo PNB.

Em matéria de proteção contra as radiações, o capítulo sobre a proteção sanitária do Tratado Euratom, originou um considerável corpus de legislação comunitária para a proteção dos trabalhadores e do público em geral.

Este arcabouço legal pode ser utilizado como parâmetro para atualização e aperfeiçoamento da nossa legislação, uma vez que sua utilização trouxe resultados positivos para a comunidade européia.

Embora o Tratado Euratom seja a base para a cooperação européia em matéria de energia nuclear, no entanto, ela já não permite responder a muitas das questões que se colocam atualmente quanto à gestão dos rejeitos radioativos ou ao descomissionamento de instalações nucleares.

Julgamos que seja necessária, uma revisão do enquadramento comunitário nessas matérias, objetivando:

- A harmonização legislativa de padrões de segurança em matéria de energia nuclear, rejeitos nucleares e instalações de produção de energia;

- O financiamento de programas de investigação e formação em matéria de radioatividade e gestão de rejeitos;

- A atualização e democratização dos procedimentos de decisão, especialmente no que se refere ao papel legislativo do Parlamento Europeu.

No âmbito da UE, o Programa Nuclear é definido pelo Sétimo ProgramaQuadro Euratom, o documento define os atuais desafios colocados pela energia nuclear na UE e apresenta as características e objetivos gerais do programa. A cada um dos três domínios temáticos de investigação, que são a energia de fusão nuclear, a energia de cisão nuclear e a proteção contra radiações, correspondem objetivos específicos dos quais decorrem toda uma série de atividades a serem implementadas no período de 2007 a 2011. 
O programa Euratom, que decorre até 2011, está subdividido em dois programas específicos. O primeiro cobre a investigação em matéria de fusão nuclear, a energia de cisão nuclear e a proteção contra radiações. $\mathrm{O}$ segundo diz respeito às ações do centro comum de investigação no domínio da energia nuclear que contribuirão para apoiar o conjunto das ações de investigação desenvolvidas em cooperação transnacional nos domínios temáticos seguintes:

- Gestão dos rejeitos nucleares, incidências no ambiente

- Seguridade

- Salvaguardas nucleares

No Brasil, vigora o monopólio estatal quanto às atividades nucleares, e todas as atividades relacionadas às questões nucleares necessitam de autorização para sua realização, por meio de licenças concedidas por instituições estatais. Tais atividades devem obedecer a rigorosas normas e regulamentos e precisam submeter-se à fiscalização de entidades também governamentais.

Entendemos que esse monopólio não está sendo benéfico para o desenvolvimento da área nuclear, bem como para a própria economia do país, por uma série de razões já expostas no decorrer desse trabalho. E quanto à fiscalização pelos órgãos governamentais, essa precisa urgentemente ser revista, uma vez que existe uma multiplicidade de fiscalização por diferentes órgãos do Governo, gerando, inclusive, conflitos de competência e objetivos. Temos, como exemplo dessa situação, a série de dificuldades impostas por diferentes órgãos do Governo, nas ações executadas pelo próprio Governo, para liberação das obras para construção da usina de Angra 3.

A política setorial, por sua vez, é formulada essencialmente pelos órgãos ministeriais responsáveis pela política energética, onde a CNEN, um órgão governamental com múltiplas funções, regulamenta, licencia e fiscaliza os usos da energia nuclear no país e, ao mesmo tempo, atua em atividades de fomento, de pesquisa e aplicação da tecnologia nuclear, além de ter sob seu controle instituições voltadas diretamente para atividades industriais. Verifica-se, assim, que o seu leque de atribuições é diverso e é conflitante, visto que a ele cabe licenciar e fiscalizar atividades que ele mesmo desempenha, adotando um restrito controle estatal e uma grande centralização das atividades nucleares. Observase que apresenta riscos inerentes, devido à ausência de segregação das funções de regulação, política nuclear e condução das atividades operacionais e que era esse o tipo de organização setorial que predominava em meados do século passado, onde a principal preocupação quanto à questão nuclear estava relacionada à defesa nacional. 
Com essa estrutura, constata-se que o arranjo institucional hoje adotado no Brasil não atende ao disposto no artigo oitavo, inciso segundo, da Convenção de Segurança Nuclear, da qual o Brasil é signatário, conforme Decreto Legislativo n. ${ }^{\circ}$ 4, de 1997 e Decreto n. ${ }^{\circ}$ 2.648, de 1998. O referido dispositivo estabelece que cada participante do acordo obriga-se em tomar as medidas apropriadas para garantir a efetiva separação entre as funções dos órgãos reguladores e dos órgãos ligados à promoção ou à utilização da energia nuclear.

Esta conjuntura demonstra que a organização institucional da área nuclear no Brasil, vem concentrando nas mãos da CNEN todo um conjunto de atividades, algumas delas de natureza contraditória, que merecem uma reavaliação.

As reflexões sobre o uso da energia nuclear como energia alternativa indicam a necessidade de que os governantes e a sociedade a percebam como um problema na ótica sistêmica. As soluções devem ocorrer nessa perspectiva, para superar os entraves criados nas esferas econômica, social e ambiental.

Os pontos positivos para a sua utilização são vários, dentre os quais destacamos:

- Estabilidade de geração, pois não está sujeita às intempéries que as renováveis estão. Por exemplo: A variação no volume do reservatório de uma hidrelétrica, os períodos sem ou com pouco vento em um aero gerador, os períodos de pouca incidência solar numa central fotovoltaica, dentre outros, acarretam variações na quantidade de energia produzida e, consequentemente, na instabilidade de fornecimento;

- Estabilidade de preços, pois a matéria prima para a sua geração é abundante e muitos dos fornecedores são países politicamente estáveis. Ainda que dependente de importação de combustível nuclear, seu custo corresponde a uma pequena parte dos gastos de produção de uma Central. O restante dos custos refere-se basicamente à construção e manutenção;

- Preços competitivos; nos últimos anos o valor pago pela eletricidade oriunda desta fonte tem sido similar, ou até inferior, que aqueles pagos pela de origens em outras, especialmente dentre as mais poluentes;

- Não contribui para o aquecimento global, sendo citada, por parte da comunidade científica, como uma alternativa energética viável que ajudaria a alcançar as metas de redução de emissão de carbono, conforme compromisso assumido, dentre outros 
países, pela UE e Brasil, ao firmarem o tratado de Kyoto, por não produzir gases de efeito estufa;

- Não emitem partículas sólidas e gases contaminantes, por não realizarem combustão propriamente dita, as centrais nucleares não liberam gases e material particulado;

- Contribui para o desenvolvimento da região onde suas usinas são instaladas, proporcionando empregos e benfeitorias para o entorno, como rodovias asfaltadas que facilitam o transporte de mercadorias e da população.

Entre os pontos negativos para a sua utilização, destacamos:

- O perigo radioativo de suas atividades, onde um simples escape de material radioativo para o ambiente poderia significar enormes danos à população e à natureza;

- O aumento da quantidade de rejeitos radioativos, gerados a partir da fissão nuclear. Equipamentos de proteção individual, tais como luvas, aventais, máscaras, ferramentas, vidraria de laboratório, dentre outros, contaminados com essas substâncias radioativas; os filtros de ar e os filtros de purificação de refrigerante; as partes de equipamento substituídas constituem os rejeitos radioativos e são classificados como rejeitos de atividade baixa e média.

Os elementos combustíveis, com os produtos de fissão e o que restou de Urânio, constituem os rejeitos de atividade alta;

- A necessidade de altos investimentos em segurança para que não haja risco de contaminação no presente e no futuro. Devido aos cuidados inerentes ao uso da tecnologia, os investimentos em segurança e outros requisitos de engenharia fazem com que as usinas nucleares sejam instalações com elevado investimento inicial. Esse fato torna as usinas nucleares competitivas somente quando são instalações de grande porte e usadas como usinas de base, ou seja, com elevada taxa de utilização da energia disponível. A instalação de usinas nucleares depende da existência de uma base tecnológica nacional, pois é fortemente dependente da capacidade regulatória dos governos, já que dependem de mecanismos de licenciamento, operação e manutenção bem estruturados, formados por grupos técnicos de alto nível;

- A resistência do público contra a energia nuclear em muitos países, influenciados pela ocorrência dos acidentes nucleares conhecidos, com o possível risco envolvendo o transporte do material nuclear e com os problemas de proliferação e terrorismo. 
Considerada essa proposta, recomendamos a adoção das seguintes ações corretivas, para sua utilização em nosso país:

1. A criação de um órgão regulador e fiscalizador autônomo e independente na área de salvaguardas nucleares, radioproteção e seguridade, provendo a segregação das atividades de fomento, pesquisa, produção e desenvolvimento das de regulação e fiscalização para dar cumprimento ao determinado pela Convenção Internacional de Segurança Nuclear da AIEA.

Com o desmembramento dessas áreas da CNEN, haveria a sua consolidação nos segmentos industriais, de consultoria em engenharia, de prestação de serviços, de treinamento e outros, além de suas atividades de desenvolvimento científico e tecnológico, parte importante de sua tradição histórica.

2. Elaboração de um arcabouço legal para a atividade reguladora nuclear, com a criação de um Sistema Federal de Fiscalização na área de radioproteção e seguridade, com a instituição de uma regulamentação da tipificação de infrações à legislação nuclear, assim como a correspondente sanção a ser aplicada.

Esta normativa legal, permitiria a implementação de um processo administrativo fiscal nuclear visando assegurar a aplicação dos preceitos constitucionais da ampla defesa e do contraditório aos infratores.

3. Criar uma carreira específica de servidor a ser lotado no órgão regulador e fiscalizador, investido com atribuições de inspeção, fiscalização e autuação dos infratores, para o efetivo cumprimento da legislação vigente.

O exercício do poder de polícia pelos servidores irá viabilizar e contribuir para o cumprimento das atribuições do órgão regulador.

4. Criação de uma legislação que disponha sobre a responsabilidade civil em caso de acidentes radiológicos.

Nessa proposta seria definida a obrigação de que as instalações que produzam, utilizam, transportam ou armazenam fontes de radiação, mantenham uma apólice de seguro, para adimplir a sua responsabilidade pelas indenizações decorrentes por danos radioativos até um determinado limite.

Somente com a criação e implementação dessa legislação, todo o hiato existente na área reguladora nuclear seria coberta, e então sim, poderíamos afirmar que a radioproteção ocupacional e ambiental praticada em nosso país, embora exista e seja efetiva, estaria de acordo com os padrões internacionais de segurança radiológica e seguridade nuclear. 
O exemplo da Argentina [Autoridade Regulatória Nuclear, (ARN)] também poderia ser seguido, uma vez que os resultados obtidos são satisfatórios e manteria uma hegemonia no Mercado Comum do Sul (MERCOSUL).

Objetivando contribuir, para que haja uma maior e cuidadosa reflexão sobre a utilização da energia nuclear, de acordo com os padrões internacionais de segurança radiológica e seguridade nuclear, e conseqüentemente, para que reformas sejam realizadas na legislação nacional vigente, visando a sua adequação e otimização, apresentamos as seguintes críticas e sugestões:

Os operadores do direito, atuantes na seara do Direito Nuclear, deparam-se todos os dias com servidores de várias instituições federais, que exercem o poder de polícia sobre algum aspecto da área nuclear, e nestas incursões, deixam claro que não existe um limite bem definido das atribuições de cada uma das instituições, fato este que tem gerado conflitos de competência, assim como possíveis irregularidades quando da atuação sem a expressa autorização da lei.

Por definição, os regulamentos de radioproteção e segurança nuclear da CNEN separaram as instalações que operam no setor nuclear em dois grupos: instalações nucleares e instalações radiativas. O primeiro grupo incorpora os reatores nucleares de potência e de pesquisa e todas as instalações do ciclo do combustível nuclear (mineração, beneficiamento e enriquecimento do Urânio, assim como a montagem de elementos combustíveis para reatores nucleares). O segundo grupo inclui as instalações médicas, industriais e de pesquisa, que utilizam fontes radioativas, além dos depósitos para armazenamento dos rejeitos radiativos.

A fiscalização das instalações radiativas, mesmo depois da ocorrência do acidente radiológico de Goiânia há mais de 21 anos, ainda hoje apresenta variadas interpretações e omissões quanto a que órgão cabe a competência legal de fiscalizá-las, Agência Nacional de Vigilância Sanitária (ANVISA), Instituto Brasileiro do Meio Ambiente e dos Recursos Naturais Renováveis (IBAMA); Ministério do Trabalho (MTE) e CNEN. Tal fato representa um comportamento inadmissível do poder público, e caso não cesse, poderá levar à repetição de evento similar de graves conseqüências.

Outra questão vigente, relacionada à competência de atuação dos órgãos, está relacionada ao licenciamento ambiental de instalações nucleares, onde persiste um conflito legal de competência entre CNEN e IBAMA ainda hoje sem solução.

Assim sendo, faz-se necessária à implantação de uma política que defina claramente o limite de atuação e competência de cada órgão, à semelhança do problema da 
competência de fiscalização de instalações radiativas, assim como procedimentos para que as instituições com prerrogativas de atuar na área nuclear trabalhem conjuntamente de forma ordenada.

Tornar flexível o monopólio na exploração de novas jazidas de Urânio, conforme o estabelecido no artigo 177 , inciso $\mathrm{V}$, da $\mathrm{CF}^{9}$, a exemplo do que se fez com o petróleo e o gás, e, tão somente, no que se refere à pesquisa e à lavra de minérios e minerais nucleares, permanecendo com a União o monopólio quanto ao enriquecimento, à industrialização e ao comércio dos mesmos, facilitando a participação de empresas privadas, propiciando assim o aumento das reservas estratégicas e exportação do excedente. Os recursos obtidos com a exportação poderiam ser destinados para a conclusão de todo o ciclo do combustivel nuclear e para o financiamento do PNB, maximizando os benefícios.

O Brasil possui reservas consideráveis de minério de Urânio e completo domínio tecnológico do ciclo do combustível nuclear, criaria oportunidades de negócios e seria um participante ativo deste mercado mundial, gerando recursos para o seu pleno desenvolvimento e garantindo a estabilidade do fornecimento elétrico do país.

Viabilizar a construção de uma central única para depósito e tratamento de rejeitos radioativos, industrial e hospitalar, através da criação de uma empresa pública com controle da União e participação acionária dos Estados da federação, pesquisando os exemplos bem sucedidos de países terceiros e os adaptando para a versão nacional.

Promover medidas políticas e práticas para minimizar e limitar, quando apropriado, a geração de rejeitos radioativos e cuidar para que tenham tratamento, acondicionamento, transporte e depósito seguros.

Apoiar os esforços realizados dentro da AIEA para desenvolver e promulgar normas ou diretrizes e códigos de prática para os rejeitos radioativos como base internacionalmente aceita para o manejo e a deposição segura e ambientalmente saudável desses rejeitos.

Incentivar a criação de uma empresa estatal brasileira para produção e distribuição de radiofármacos, objetivando consolidar o domínio da tecnologia nacional já existente, ampliar a produção com baixo custo final para o atendimento de toda a população e dar suporte à substituição de importações de matérias-primas básicas (radioisótopos) da produção encontrada no mercado.

Fomentar a construção de um reator nacional multi propósito, de tamanho médio, a ser destinado à produção de radiofármacos e testes com materiais. 
Promover o fim do monopólio do governo para os materiais cujos radioisótopos sejam utilizados em instalações radiativas propiciando a sua utilização pela iniciativa privada, ampliando o mercado de trabalho, a concorrência e o atendimento da população, contribuindo com desenvolvimento de novas pesquisas na área. Considerados como radioisótopos de meia vida curta pela AIEA.

Promover o fim do monopólio do governo na construção e na operação de reatores nucleares que produzam energia elétrica, abrindo o mercado para empresas com pelo menos $60 \%$ de capital nacional, objetivando incentivar a participação do capital privado e o desenvolvimento da tecnologia no setor.

Desenvolver programas de formação e treinamento em grande escala de pessoal para a área nuclear, não só em nível superior, mas também em nível técnico, nas áreas de radioproteção e metrologia das radiações, entre outras, dirigindo esses serviços e capacitações não só para uso interno, mas também para intercâmbios e até mesmo exportação para países detentores da tecnologia em escalas menos desenvolvidas que o Brasil, inclusive na área do Direito Nuclear em virtude de fiscalizações, sanções, e outras, pelos órgãos competentes. 


\section{CONCLUSÕES}

O presente estudo demonstrou que a radioproteção ocupacional e ambiental praticada no Brasil, embora exista e seja efetiva, não está ainda, no nível dos padrões internacionais de segurança radiológica e seguridade nuclear. Para modificar esta situação, a legislação nacional na área, teria que mudar efetivamente já no âmbito constitucional, redefinindo competências e responsabilidades, objetivando a proteção dos trabalhadores, da população e a preservação do meio ambiente dos efeitos indesejáveis da energia nuclear, pressupostos fundamentais a serem observados na organização das empresas e da pesquisa, seguindo os padrões e acordos internacionais.

A Convenção Internacional de Segurança Nuclear (CISN) não está sendo cumprida pelo Brasil, ressaltamos que o país tornou-se signatário da CISN, através do Decreto n. ${ }^{\circ} 2648$ de $1 .^{\circ}$ de julho de 1999.

O referido Decreto reconhece a necessidade da criação de um órgão regulatório, licenciador e fiscalizador para atividades envolvendo as usinas nucleares, assim como estabelece instrumentos legais necessários para a sua constituição ao promulgar o Protocolo da CISN.

A CISN em seu artigo 7. "Estrutura Legal e Regulatória" determina que:

1- Cada parte contratante estabelecerá e manterá uma estrutura legislativa e regulatória para governar a segurança das instalações nucleares;

2- A estrutura legal e regulatória disporá sobre:

I- o estabelecimento de requisitos e regulamentações nacionais de segurança;

II- um sistema de licenciamento para as instalações nucleares e a proibição de operação da instalação nuclear sem uma licença;

III- um sistema de inspeção regulatória e avaliação de instalações nucleares para apurar o cumprimento de regulamentos aplicáveis e dos termos de licenças;

IV- o cumprimento dos regulamentos aplicáveis e dos termos de licenças, incluindo suspensão, modificação ou revogação.

Isto fica evidente no artigo $8 .^{\circ}$ "órgão regulatório" da CISN ao determinar que:

1- Cada parte contratante (Brasil) estabelecerá ou designará um órgão regulatório, encarregado da implementação do arcabouço legislativo e regulatório referido 
no artigo $7 .^{\circ}$, e dotado de autoridade adequada, competência e recursos financeiros e humanos para desincumbir-se das responsabilidades a ele atribuídas;

2- Cada parte contratante tomará as medidas apropriadas para assegurar uma efetiva separação entre as funções do órgão regulatório e aquelas de qualquer outro órgão ou organização relacionado com a promoção ou utilização da energia nuclear.

Ainda, o artigo $8 .^{\circ}$ deixa claro que a CNEN não pode ser esse órgão regulatório ao estabelecer a necessidade de separação das funções regulatórias daquelas de promoção, tendo em vista que a CNEN é responsável pelo desenvolvimento tecnológico da área nuclear, opera quatro reatores de pesquisa, dirige quatro instituições de pesquisa com instalações experimentais do ciclo do combustivel nuclear, controla a INB, responsável pela indústria do ciclo do combustível nuclear, presta serviços de engenharia para a ELETRONUCLEAR, empresa operadora das usinas nucleares brasileiras, para a INB e para a Marinha, atividades que se identificam claramente como de promoção ou utilização da energia nuclear. Esses fatos demonstram a interveniência da CNEN nos usos da energia nuclear, através de um conjunto de ações incompatíveis com a necessidade da independência da regulamentação, do licenciamento e da fiscalização, indispensável para a real garantia da segurança das instalações nucleares no Brasil.

Resta, portanto, ao Governo Brasileiro, a criação do órgão regulatório, orientado pelos artigos $7 .^{\circ}$ e $8 .^{\circ}$ "Estrutura Legal e Regulatória" da CISN, vinculado à Presidência da República, para que possa se impor politicamente no exercício de suas atribuições sobre todos os Ministérios que, de uma forma ou de outra, tenham que requerer licenças ou autorizações para construir ou operar na área nuclear. Promovendo o fortalecimento da área de segurança nuclear com a criação de um órgão licenciador e fiscalizador independente, medidas que garantirão menos sobressaltos com acidentes que, eventualmente, poderiam inviabilizar os usos da energia nuclear nas áreas industriais, médicas e de geração de energia, tão necessárias ao desenvolvimento nacional.

O arcabouço legal das atividades de regulação e fiscalização da área nuclear é praticamente inexistente, não apresentando um instrumental mínimo para a formalização de uma atividade de fiscalização eficiente e capaz de assegurar o devido controle sobre o setor.

O órgão regulador da área nuclear não sabe qual é o limite de suas atribuições, o que vem gerando conflito de competência com a ANVISA, IBAMA e até mesmo, com a fiscalização do MTE. 
Ainda em comparação com os órgãos federais supracitados, com relação à atribuição de fiscalização, é notória a existência de um enorme hiato na instrumentalização da fiscalização na área nuclear.

Além do mais, tampouco existe uma legislação que tipifique as infrações e institua as penalidades aos infratores, o que dotaria o setor de poder coercitivo sobre seus fiscalizados.

O Governo ainda esta tratando a área nuclear com uma visão de soberania e defesa nacional, quando poderia, ao contrário, adotar uma postura mais democrática e moderna, voltada para o uso pacífico de suas aplicações, objetivando a segurança da população e do meio ambiente.

Há necessidade de desenvolvimento de instrumentos que possibilitem a democratização do acesso às informações, assim como a adoção de um enfoque participativo da sociedade e o tratamento aberto das questões controversas.

Decisões sobre nosso desenvolvimento nuclear são urgentes, sob pena de perdermos as oportunidades geradas pelo mercado nuclear aquecido, correndo, ainda, o risco de deteriorarmos ou tornarmos obsoleta nossa capacitação tecnológica, arduamente adquirida nos últimos 50 anos do ciclo do combustível nuclear e em alguns segmentos da tecnologia de reatores nucleares.

Diante do exposto, concluímos que os objetivos propostos foram alcançados e o setor da energia nuclear pode gerar os recursos necessários para seu próprio financiamento, dependendo apenas de um posicionamento político do governo e o estabelecimento de um novo marco regulatório, objetivando garantir a segurança do suprimento, a qualidade dos serviços e tarifas módicas ao consumidor para esse segmento estratégico. 


\section{FUTUROS TRABALHOS}

1. O presente trabalho tratou do Direito Nuclear em um nível hierárquico elevado abrangendo os três poderes em um primeiro escalão. O mesmo trabalho pode ser desenvolvido em escalões inferiores envolvendo as instituições subordinadas aos diferentes Ministérios como CNEN, Departamento de Transportes, terrestre, aquático, aéreo, entre outros.

2. Efetuar um estudo das possíveis competências com relação ao que deveria ser legislação federal, estadual e municipal.

3. Efetuar um estudo com o intuito de separar os assuntos do Direito Nuclear, que deveriam ser objeto de Lei, Decreto Legislativo, Decreto-Lei e Decreto, levando em consideração que a parte científica e tecnológica está em franco desenvolvimento e os conhecimentos são duplicados em poucos anos e, nesse caso, para manter a atualização, principalmente em proteção, segurança e seguridade os regulamentos são mais flexíveis e rápidos a mudanças.

4. Efetuar estudos detalhados normativos com relação às exigências de formação e treinamento de trabalhadores nas atividades nucleares e radiológicas como de especialistas em radioproteção e também em Direito Nuclear. 


\section{APÊNDICE - CONSOLIDADO DA LEGISLAÇÃO NA ÁREA NUCLEAR}

DECRETO - Relação histórica com respectivos objetos

Decreto 6.129 de 20/06/07

DISPÕE SOBRE A VINCULAÇÃO DAS ENTIDADES INTEGRANTES DA ADMINISTRAÇÃO PÚBLICA FEDERAL INDIRETA.

\section{Decreto 5.886 de 06/09/06}

APROVA A ESTRUTURA REGIMENTAL E O QUADRO DEMONSTRATIVO DOS CARGOS EM COMISSÃO E DAS FUNÇÕES GRATIFICADAS DO MINISTÉRIO DA CIÊNCIA E TECNOLOGIA E DÁ OUTRAS PROVIDÊNCIAS.

\section{Decreto 5.885 de 05/09/06}

PROMULGA O ACORDO REGIONAL DE COOPERAÇÃO PARA A PROMOÇÃO DA CIÊNCIA E DA TECNOLOGIA NUCLEARES NA AMÉRICA LATINA E NO CARIBE - ARCAL, CELEBRADO NO ÂMBITO DA AGÊNCIA INTERNACIONAL DE ENERGIA ATÔMICA - AIEA, ADOTADO EM VIENA, EM 25 DE SETEMBRO DE 1998, E ASSINADO PELO BRASIL EM 4 DE AGOSTO DE 1999, COM RESERVAS AOS ARTIGOS VI E XIII.

\section{Decreto 5.812 de 21/06/06}

PROMULGA O ACORDO DE COOPERAÇÃO ENTRE O GOVERNO DA REPÚBLICA FEDERATIVA DO BRASIL E O GOVERNO DA REPÚBLICA DO CHILE NO CAMPO DOS USOS PACÍFICOS DA ENERGIA NUCLEAR, CELEBRADO EM ARICA, EM 20 DE MARÇO DE 2002. 


\section{Decreto 5.667 de 10/01/06}

APROVA A ESTRUTURA REGIMENTAL E O QUADRO DEMONSTRATIVO DOS CARGOS EM COMISSÃO E DAS FUNÇÕES GRATIFICADAS DA COMISSÃO NACIONAL DE ENERGIA NUCLEAR - CNEN, E DÁ OUTRAS PROVIDÊNCIAS.

\section{Decreto 5.555 de 04/10/05}

PROMULGA O ACORDO ENTRE O GOVERNO DA REPÚBLICA FEDERATIVA DO BRASIL E O GOVERNO DA REPÚBLICA DA CORÉIA COOPERAÇÃO NOS USOS PACÍFICOS DA ENERGIA NUCLEAR, CELEBRADO EM SEUL, EM 18 DE JANEIRO DE 2001.

\section{Decreto 5.517 de 23/08/05}

PROMULGA O ACORDO DE COOPERAÇÃO ENTRE O GOVERNO DA REPÚBLICA FEDERATIVA DO BRASIL E O GOVERNO DA REPÚBLICA FRANCESA PARA O DESENVOLVIMENTO DAS UTILIZAÇÕES PACÍFICAS DA ENERGIA NUCLEAR, CELEBRADO EM PARIS, EM 25 DE OUTUBRO DE 2002.

\section{Decreto 5.473 de 21/06/05}

PRORROGA O PRAZO FIXADO NO ART. $2^{\circ}$ DO DECRETO N ${ }^{\circ} 2.413$, DE 4 DE DEZEMBRO DE 1997, QUE DISPÕE SOBRE AS ATRIBUIÇÕES DA COMISSÃO NACIONAL DE ENERGIA NUCLEAR - CNEN NAS ATIVIDADES DE INDUSTRIALIZAÇÃO, IMPORTAÇÃO E EXPORTAÇÃO DE MINERAIS E MINÉRIOS DE LÍTIO E SEUS DERIVADOS.

\section{Decreto 5.438 de 29/04/05}

AUTORIZA A COMISSÃO NACIONAL DE ENERGIA NUCLEAR - CNEN A VENDER O TERRENO DENOMINADO "CAMPO DE ROMA". 


\section{Decreto 5.430 de 20/04/05}

APROVA A ESTRUTURA REGIMENTAL E O QUADRO DEMONSTRATIVO DOS CARGOS EM COMISSÃO E DAS FUNÇÕES GRATIFICADAS DA COMISSÃO NACIONAL DE ENERGIA NUCLEAR - CNEN, E DÁ OUTRAS PROVIDÊNCIAS.

\section{Decreto 5.287 de 26/11/04}

ALTERA DISPOSITIVOS DOS DECRETOS NOS 62.724, DE 17 DE MAIO DE 1968, QUE ESTABELECE NORMAS GERAIS DE TARIFAÇÃO PARA EMPRESAS CONCESSIONÁRIAS DE SERVIÇOS PÚBLICOS DE ENERGIA ELÉTRICA, E 4.550, DE 27 DE DEZEMBRO DE 2002, QUE REGULAMENTA A COMERCIALIZAÇÃO DE ENERGIA ELÉTRICA GERADA PELA ELETROBRÁS TERMONUCLEAR S.A. ELETRONUCLEAR E POR ITAIPU BINACIONAL, E DÁ OUTRAS PROVIDÊNCIAS.

\section{Decreto 4.899 de 26/11/03}

APROVA ALTERAÇÕES NO ESTATUTO SOCIAL DA ELETROBRÁS TERMONUCLEAR S.A. - ELETRONUCLEAR, APROVADO PELO DECRETO DE 23 DE DEZEMBRO DE 1997.

\section{Decreto 4.696 de 12/05/03}

APROVA A ESTRUTURA REGIMENTAL E O QUADRO DEMONSTRATIVO DOS CARGOS EM COMISSÃO E DAS FUNÇÕES GRATIFICADAS DA COMISSÃO NACIONAL DE ENERGIA NUCLEAR - CNEN, E DÁ OUTRAS PROVIDÊNCIAS.

\section{Decreto 4.550 de 27/12/02}

REGULAMENTA A COMERCIALIZAÇÃO DE ENERGIA ELÉTRICA GERADA PELA ELETROBRÁS TERMONUCLEAR S/A - ELETRONUCLEAR, POR ITAIPU BINACIONAL E DÁ OUTRAS PROVIDÊNCIAS. 


\section{Decreto 4.338 de 19/08/02}

PRORROGA O PRAZO FIXADO NO ART. $2^{\circ}$ DO DECRETO NO 2.413, DE 4 DE DEZEMBRO DE 1997, QUE DISPÕE SOBRE AS ATRIBUIÇÕES DA COMISSÃO NACIONAL DE ENERGIA NUCLEAR NAS ATIVIDADES DE INDUSTRIALIZAÇÃO, IMPORTAÇÃO E EXPORTAÇÃO DE MINERAIS E MINÉRIOS DE LÍTIO E SEUS DERIVADOS.

\section{Decreto 4.214 de 30/04/02}

DEFINE A COMPETÊNCIA DA COMISSÃO INTERMINISTERIAL DE CONTROLE DE EXPORTAÇÃO DE BENS SENSÍVEIS, DE QUE TRATA A LEI No 9.112, DE 10 DE OUTUBRO DE 1995, E DÁ OUTRAS PROVIDÊNCIAS.

\section{Decreto 4.096 de 22/01/02}

CONSIDERAM DE NATUREZA MILITAR OS CARGOS OCUPADOS POR MILITARES DA ATIVA DAS FORÇAS ARMADAS, NO MINISTERIO DA CIENCIA E TECNOLOGIA, E DA OUTRAS PROVIDENCIAS.

\section{Decreto 3.208 de 13/10/99}

PROMULGA O ACORDO DE COOPERAÇÃO ENTRE O GOVERNO DA REPUBLICA FEDERATIVA DO BRASIL E O GOVERNO DOS ESTADOS UNIDOS DA AMERICA SOBRE OS USOS PACIFICOS DE ENERGIA NUCLEAR CELEBRADO EM BRASILIA, EM 14 DE OUTUBRO DE 1997.

\section{Decreto 2.864 de 07/12/98}

PROMULGA O TRATADO SOBRE A NÃO-PROLIFERAÇÃO DE ARMAS NUCLEARES, ASSINADO EM LONDRES, MOSCOU E WASHINGTON, EM 1 DE JULHO DE 1968. 


\section{Decreto 2.750 de 26/08/98}

PROMULGA O ACORDO PARA COOPERAÇÃO NOS USOS PACIFICOS DA ENERGIA NUCLEAR, CELEBRADO ENTRE O GOVERNO DA REPUBLICA FEDERATIVA DO BRASIL E O GOVERNO DA FEDERAÇÃO DA RUSSIA, EM BRASILIA, EM 15 DE SETEMBRO DE 1994.

\section{Decreto 2.648 de 01/07/98}

PROMULGA O PROTOCOLO DA CONVENÇÃO DE SEGURANÇA NUCLEAR, ASSINADA EM VIENA, EM 20 DE SETEMBRO DE 1994.

\section{Decreto 2.606 de 27/05/98}

PROMULGA O ACORDO PARA COOPERAÇÃO NOS USOS PACIFICOS DA ENERGIA NUCLEAR CELEBRADO ENTRE O GOVERNO DA REPUBLICA FEDERATIVA DO BRASIL E O GOVERNO DO CANADA, EM BRASILIA, EM 22 DE MAIO DE 1996.

Decreto de 23/12/97

APROVA ALTERAÇÕES DO ESTATUTO SOCIAL E DA DENOMINAÇÃO DA NUCLEN ENGENHARIA E SERVIÇOS S.A.

\section{Decreto 2.413 de 04/12/97}

DISPÕE SOBRE AS ATRIBUIÇÕES DA COMISSÃO NACIONAL DE ENERGIA NUCLEAR NAS ATIVIDADES DE INDUSTRIALIZAÇÃO, IMPORTAÇÃO E EXPORTAÇÃO DE MINERAIS E MINÉRIOS DE LÍTIO E SEUS DERIVADOS. 


\section{Decreto de 23/05/97}

AUTORIZA A CISÃO DE FURNAS - CENTRAIS ELETRICAS S.A., ALTERA O OBJETO SOCIAL DA NUCLEN - ENGENHARIA E SERVIÇOS S.A., AUTORIZA A TRANSFERENCIA DA AUTORIZAÇÃO PARA CONSTRUÇÃO E OPERAÇÃO DA CENTRAL NUCLEAR ALMIRANTE ALVARO ALBERTO E DA OUTRAS PROVIDENCIAS.

\section{Decreto 2.210 de 22/04/97}

REGULAMENTA O DECRETO-LEI N 1.809, DE 7 DE OUTUBRO DE 1980, QUE INSTITUIU O SISTEMA DE PROTEÇÃO AO PROGRAMA NUCLEAR BRASILEIRO - SEPRON, E DÁ OUTRAS PROVIDÊNCIAS.

\section{Decreto 1.861 de 12/04/96}

REGULAMENTA A EXPORTAÇÃO DE BENS SENSIVEIS E SERVIÇOS DIRETAMENTE VINCULADOS, DE QUE TRATA A LEI 9.112, DE 10 DE OUTUBRO DE 1995.

\section{Decreto 1.246 de 16/09/94}

PROMULGA O TRATADO PARA A PROSCRIÇÃO DAS ARMAS NUCLEARES NA AMERICA LATINA E NO CARIBE (TRATADO DE TLATELOLCO), CONCLUIDO NA CIDADE DO MEXICO, EM 14 DE FEVEREIRO DE 1967, E AS RESOLUÇÕES 267 (E-V), DE 3 DE JULHO DE 1990, 268 (XII), DE 10 DE MAIO DE 1991, E 290 (VII), DE 26 DE AGOSTO DE 1992, AS TRES ADOTADAS PELA CONFERENCIA GERAL DO ORGANISMO PARA A PROSCRIÇÃO DAS ARMAS NUCLEARES NA AMERICA LATINA E NO CARIBE - OPANAL, NA CIDADE DO MEXICO. 
Decreto 1.090 de 21/03/94

PROMULGA O ACORDO ENTRE O GOVERNO DA REPUBLICA FEDERATIVA DO BRASIL E A AGENCIA BRASILEIROARGENTINA DE CONTABILIDADE E CONTROLE DE MATERIAIS NUCLEARES - ABACC SOBRE SUAS OBRIGAÇÕES, PRIVILEGIOS E IMUNIDADES, DE 27/03/92.

\section{Decreto 1.065 de 24/02/94}

PROMULGA O ACORDO ENTRE A REPUBLICA FEDERATIVA DO BRASIL, A REPUBLICA ARGENTINA, A AGENCIA BRASILEIRO-ARGENTINA DE CONTABILIDADE E CONTROLE DE MATERIAIS NUCLEARES - ABACC E A AGENCIA INTERNACIONAL DE ENERGIA ATOMICA - AIEA PARA A APLICAÇÃO DE SALVAGUARDAS.

\section{Decreto de 05/01/94}

AUTORIZA A INB A INCORPORAR SUAS CONTROLADAS NUCLEI, URÂNIO E NUCLEMON.

\section{Decreto 0-005 de 08/12/93}

DISPÕE SOBRE A TRANSFERENCIA DA SEDE DA COMISSÃO NACIONAL DE ENERGIA NUCLEAR - CNEN PARA O MUNICIPIO DO RIO DE JANEIRO.

\section{Decreto 830 de 03/06/93}

PROMULGA O ACORDO DE COOPERAÇÃO NO CAMPO DOS USOS PACIFICOS DA ENERGIA NUCLEAR, ENTRE O GOVERNO DA REPUBLICA FEDERATIVA DO BRASIL E O GOVERNO DA ESPANHA, DE 12/05/1983. 
Decreto 515 de 29/04/92

PROMULGA O PROTOCOLO ADICIONAL SOBRE PRIVILEGIOS E IMUNIDADES AO ACORDO PARA O USO EXCLUSIVAMENTE PACIFICO DA ENERGIA NUCLEAR, ENTRE O GOVERNO DA REPUBLICA FEDERATIVA DO BRASIL E O GOVERNO DA REPUBLICA ARGENTINA.

Decreto 439 de 03/02/92

PROMULGA O ACORDO PARA O USO EXCLUSIVAMENTE PACIFICO DA ENERGIA NUCLEAR, ENTRE O GOVERNO DA REPUBLICA FEDERATIVA DO BRASIL E O GOVERNO DA REPUBLICA ARGENTINA.

\section{Decreto 422 de 14/01/92}

PROMULGA O ACORDO DE COOPERAÇÃO NA AREA DA ENERGIA NUCLEAR PARA FINS PACIFICOS, ENTRE O GOVERNO DA REPUBLICA FEDERATIVA DO BRASIL E O GOVERNO DA REPUBLICA DA VENEZUELA.

\section{Decreto 95 de 16/04/91}

PROMULGA A CONVENÇÃO SOBRE A PROTEÇÃO FISICA DO MATERIAL NUCLEAR.

\section{Decreto 9 de 15/01/91}

PROMULGA A CONVENÇÃO SOBRE PRONTA NOTIFICAÇÃO DE ACIDENTE NUCLEAR.

\section{Decreto 8 de 15/01/91}

PROMULGA A CONVENÇÃO SOBRE ASSISTENCIA NO CASO DE ACIDENTE NUCLEAR OU EMERGENCIA RADIOLOGICA. 
Decreto 97.211 de 12/12/88

PROMULGA O TRATADO SOBRE A PROIBIÇÃO DA COLOCAÇÃO DE ARMAS NUCLEARES E OUTRAS ARMAS DE DESTRUIÇÃO EM MASSA NO LEITO DO MAR E NO FUNDO DO OCEANO E EM SEU SUBSOLO.

\section{Decreto 95645 de 14/01/88}

PROMULGA O ACORDO PARA A COOPERAÇÃO NOS USOS PACIFICOS DA ENERGIA NUCLEAR, ENTRE A REPUBLICA FEDERATIVA DO BRASIL E A REPUBLICA POPULAR DA CHINA.

\section{Decreto 92501 de 26/03/86}

PROMULGA O ACORDO DE COOPERAÇÃO SOBRE O USO PACIFICO DA ENERGIA NUCLEAR ENTRE A REPUBLICA FEDERATIVA DO BRASIL E A REPUBLICA DA COLOMBIA.

Decreto 91981 de 25/11/85

ESTABELECE CRITERIOS PARA ABSORÇÃO DE CUSTOS RELATIVOS À UNIDADE I DA CENTRAL NUCLEAR ALMIRANTE ALVARO ALBERTO - ANGRA 1, EXCEDENTES A OPÇÃO HIDROELETRICA.

\section{Decreto 90857 de 24/01/85}

ESTABELECE RESERVA DE MINERIOS NUCLEARES, DE SEUS CONCENTRADOS OU DE COMPOSTOS QUIMICOS DE ELEMENTOS NUCLEARES, DISPÕE SOBRE ESTOQUE DE MATERIAL FERTIL E FISSIL ESPECIAL E DA OUTRAS PROVIDENCIAS. 
Decreto 88946 de 07/11/83

PROMULGA O ACORDO DE COOPERAÇÃO PARA O DESENVOLVIMENTO E A APLICAÇÃO DOS USOS PACIFICOS DA ENERGIA NUCLEAR ENTRE O GOVERNO DA REPUBLICA FEDERATIVA DO BRASIL E O GOVERNO DA REPUBLICA ARGENTINA.

\section{Decreto 86511 de 27/10/81}

PROMULGA O ACORDO ENTRE O GOVERNO DA REPUBLICA FEDERATIVA DO BRASIL E A REPUBLICA DO IRAQUE SOBRE OS USOS PACIFICOS DA ENERGIA NUCLEAR.

Decreto 84973 de 29/07/80

DISPÕE SOBRE A COLOCALIZAÇÃO DE ESTAÇÕES ECOLOGICAS E USINAS NUCLEARES.

Decreto 82079 de 03/08/78

PROMULGA O ACORDO SOBRE COOPERAÇÃO NO CAMPO DOS USOS PACIFICOS DA ENERGIA ATOMICA, ENTRE O BRASIL E O PERU.

Decreto 81384 de 22/02/78

DISPÕE SOBRE A CONCESSÃO DE GRATIFICAÇÃO POR ATIVIDADES COM RAIOS-X OU SUBSTANCIAS RADIOATIVA E OUTRAS VANTAGENS, PREVISTAS NA LEI 1.234 DE 14 DE NOVEMBRO DE 1950, E DA OUTRAS PROVIDENCIAS. 
DISPÕE SOBRE A TRANSPOSIÇÃO E TRANSFORMAÇÃO DE EMPREGOS PARA CATEGORIAS FUNCIONAIS DOS GRUPOS PESQUISA CIENTIFICA E TECNOLOGICA, ARTESANATO, SERVIÇOS AUXILIARES, OUTRAS ATIVIDADES DE NIVEL SUPERIOR, OUTRAS ATIVIDADES DE NIVEL MEDIO, SERVIÇOS JURIDICOS E SERVIÇOS DE TRANSPORTE OFICIAL E PORTARIA, DA TABELA PERMANENTE DA COMISSÃO NACIONAL DE ENERGIA NUCLEAR - CNEN, E DA OUTRAS PROVIDENCIAS.

Decreto 76805 de 16/12/75

AUTORIZA A CRIAÇÃO DA NUCLEBRAS EQUIPAMENTOS PESADOS S.A. NUCLEP, SOCIEDADE POR AÇÕES, SUBSIDIARIA DA EMPRESAS NUCLEARES BRASILEIRAS S.A. - NUCLEBRAS.

Decreto 76803 de 16/12/75

AUTORIZA A CRIAÇÃO DA NUCLEBRAS ENGENHARIA S.A. - NUCLEN, SOCIEDADE POR AÇÕES, SUBSIDIARIA DA EMPRESAS NUCLEARES BRASILEIRAS S.A. - NUCLEBRAS.

Decreto 76695 de 01/12/75

PROMULGA O ACORDO SOBRE COOPERAÇÃO NO CAMPO DOS USOS PACIFICOS DA ENERGIA NUCLEAR BRASIL-REPUBLICA FEDERAL DA ALEMANHA.

Decreto 74600 de 24/09/74

PROMULGA O CONVENIO SOBRE A ENTRADA DE NAVIOS NUCLEARES EM AGUAS BRASILEIRAS E SUA PERMANENCIA EM PORTOS BRASILEIROS. 
Decreto 71207 de 05/10/72

PROMULGA O ACORDO DE COOPERAÇÃO RELATIVO AOS USOS CIVIS DA ENERGIA ATOMICA ENTRE O BRASIL E OS ESTADOS UNIDOS DA AMERICA E A EMENDA AO ACORDO ENTRE A AGENCIA INTERNACIONAL DE ENERGIA ATOMICA, O GOVERNO DA REPUBLICA FEDERATIVA DO BRASIL E O GOVERNO DOS ESTADOS UNIDOS DA AMERICA PARA A APLICAÇÃO DE SALVAGUARDAS.

Decreto 70855 de 21/07/72

REGULA A EXECUÇÃO DO DISPOSTO NOS ARTIGOS 15, 16 E 17 DA LEI 5.740, DE 01 DE DEZEMBRO DE 1971.

Decreto 66607 de 20/05/70

PROMULGA O ACORDO SOBRE A COOPERAÇÃO PARA UTILIZAÇÃO PACIFICA DA ENERGIA NUCLEAR ENTRE O BRASIL E A INDIA.

Decreto 66606 de 20/05/70

PROMULGA O ACORDO SOBRE UTILIZAÇÃO DA ENERGIA ATOMICA PARA FINS PACIFICOS COM A ESPANHA.

Decreto 66255 de 24/02/70

PROMULGA O ACORDO SOBRE COOPERAÇÃO NO CAMPO DOS USOS PACIFICOS DA ENERGIA ATOMICA ENTRE A REPUBLICA FEDERATIVA DO BRASIL E A BOLIVIA.

Decreto 65811 de 08/12/69

PROMULGA O ACORDO DE COOPERAÇÃO PARA A UTILIZAÇÃO DA ENERGIA ATOMICA PARA FINS PACIFICOS COM A SUIÇA. 
Decreto 63705 de 29/11/68

PROMULGAM O ACORDO PARA APLICAÇÃO DE SALVAGUARDAS ENTRE O BRASIL, OS ESTADOS UNIDOS E AGENCIA INTERNACIONAL DE ENERGIA ATOMICA - AIEA.

Decreto 63152 de 22/08/68

PROMULGA O ACORDO PARA A UTILIZAÇÃO DA ENERGIA ATOMICA PARA FINS PACIFICOS, COM A SUIÇA.

Decreto 61517 de 03/06/68

PROMULGA O ACORDO DE COOPERAÇÃO PARA USOS CIVIS DE ENERGIA ATOMICA, COM OS ESTADOS UNIDOS.

Decreto 62710 de 16/05/68

ALTERA O ARTIGO 2 DO DECRETO 53.735 DE 18 DE MARÇO DE 1961, PARA MODIFICAR A FORMAÇÃO DO CAPITAL DA SOCIEDADE SUBSIDIARIA A SER CONSTITUIDA PELA COMISSÃO NACIONAL DE ENERGIA NUCLEAR- CNEN.

Decreto 62521 de 15/04/68

PROMULGA O ACORDO PARA A COOPERAÇÃO NA UTILIZAÇÃO DA ENERGIA NUCLEAR PARA FINS PACIFICOS, COM PORTUGAL.

Decreto 59309 de 23/09/66

PROMULGA O ACORDO SOBRE PRIVILEGIOS E IMUNIDADES DA AGENCIA INTERNACIONAL DE ENERGIA ATOMICA - AIEA. 
Decreto 59308 de 23/09/66

PROMULGA O ACORDO BASICO DE ASSISTENCIA TECNICA COM A ORGANIZAÇÃO DAS NAÇÕES UNIDAS, SUAS AGENCIAS ESPECIALIZADAS E A AGENCIA INTERNACIONAL DE ENERGIA ATOMICA - AIEA.

\section{Decreto 59251 de 20/09/66}

PROMULGA O ACORDO DE COOPERAÇÃO NO CAMPO DAS UTILIZAÇÕES PACÍFICAS DA ENERGIA ATOMICA COM A COMUNIDADE EUROPEIA DE ENERGIA ATOMICA.

\section{Decreto 58256 de 26/04/66}

PROMULGA O TRATADO DE PRESCRIÇÃO DAS EXPERIENCIAS COM ARMAS NUCLEARES NA ATMOSFERA, NO ESPAÇO COSMICO E SOB A AGUA.

\section{Decreto 56618 de 27/07/65}

PROMULGA O ACORDO SOBRE COOPERAÇÃO NO CAMPO DOS USOS PACIFICOS DA ENERGIA ATOMICA COM O PARAGUAI.

\section{Decreto 54496 de 16/10/64}

PROMULGA O ACORDO DE COOPERAÇÃO PARA EMPREGO PACIFICO DA ENERGIA NUCLEAR BRASIL FRANÇA.

\section{Decreto 53735 de 18/03/64}

AUTORIZA A COMISSÃO NACIONAL DE ENERGIA NUCLEAR - CNEN, A CRIAR UMA SOCIEDADE SUBSIDIARIA E SUBSCREVER A MAIORIA DE SUAS AÇÕES. 


\section{Decreto 52021 de 20/05/63}

PROMULGA O ACORDO DE COOPERAÇÃO ENTRE O BRASIL E A ITALIA PARA O USO PACIFICO DA ENERGIA NUCLEAR.

\section{Decreto 51726 de 19/02/63}

APROVA O REGULAMENTO PARA EXECUÇÃO DA LEI 4.118, DE 27 DE AGOSTO DE 1962 (POLITICA NACIONAL DE ENERGIA NUCLEAR CRIA A COMISSÃO NACIONAL DE ENERGIA NUCLEAR - CNEN, E DA OUTRAS PROVIDENCIAS).

Decreto 51621 de 14/12/62

TORNA PUBLICAS RATIFICAÇÕES E ADESÕES POR PARTE DE DIVERSOS PAISES AO ESTATUTO DA AGENCIA INTERNACIONAL DE ENERGIA ATOMICA - AIEA, ADOTADO EM NOVA YORK, A 26 DE OUTUBRO DE 1956.

Decreto 40110 de 10/10/56

CRIA A COMISSÃO NACIONAL DE ENERGIA NUCLEAR - CNEN, E DAS OUTRAS PROVIDENCIAS. 
DECRETO - LEI - Relação histórica com respectivos objetos

\section{Decreto-Lei 2.464 de 31/08/88}

ALTERA A DENOMINAÇÃO DA EMPRESAS NUCLEARES BRASILEIRAS S.ANUCLEBRÁS, TRANSFERE BENS DE SUA PROPRIEDADE, E DÁ OUTRAS PROVIDÊNCIAS.

\section{Decreto-Lei 1.982 de 28/12/82}

DISPÕE SOBRE O EXERCICIO DAS ATIVIDADES NUCLEARES INCLUIDAS NO MONOPOLIO DA UNIÃO, O CONTROLE DO DESENVOLVIMENTO DE PESQUISAS NO CAMPO DA ENERGIA NUCLEAR, E DA OUTRAS PROVIDENCIAS.

\section{Decreto-Lei 1.865 de 26/02/81}

DISPÕE SOBRE A OCUPAÇÃO PROVISORIA DE IMOVEIS PARA PESQUISA E LAVRA DE SUBSTANCIAS MINERAIS QUE CONTENHAM ELEMENTOS NUCLEARES.

Decreto-Lei 1.810 de 23/10/80

DISPÕE SOBRE A CONSTRUÇÃO DE USINAS NUCLEOELÉTRICAS.

Decreto-Lei 1.809 de 07/10/80

INSTITUI O SISTEMA DE PROTEÇÃO AO PROGRAMA NUCLEAR BRASILEIRO, E DÁ OUTRAS PROVIDÊNCIAS.

\section{Decreto-Lei 542 de 18/04/69}

APROVA O ACORDO DE COOPERAÇÃO SOBRE A UTILIZAÇÃO DA ENERGIA ATOMICA PARA FINS PACIFICOS, ASSINADO EM MADRID, A 27 DE MAIO DE 1968, COM A ESPANHA. 
Decreto-Lei 537 de 17/04/69

APROVA O ACORDO DE COOPERAÇÃO SOBRE A UTILIZAÇÃO PACIFICA DA ENERGIA NUCLEAR, ASSINADO NO RIO DE JANEIRO, EM 18 DE DEZEMBRO DE 1968, COM A INDIA.

\section{Decreto-Lei 330 de 13/09/67}

REVOGA DISPOSITIVOS DO DECRETO-LEI 227, DE 28 DE FEVEREIRO DE 1967, ALTERADO PELO DECRETOLEI 318, DE 14 DE MARÇO DE 1967 (CODIGO DE MINAS) E RESTAURA VIGENCIA DO ARTIGO 33, DA LEI 4.118, DE 27 DE AGOSTO DE 1962. 
DECRETO LEGISLATIVO - Relação histórica com respectivos objetos

\section{Decreto Legislativo 4626 de 17/04/06}

APROVA O TEXTO DO ACORDO DE COOPERAÇÃO ENTRE O GOVERNO DA REPÚBLICA FEDERATIVA DO BRASIL E O GOVERNO DA REPÚBLICA DO CHILE NO CAMPO DOS USOS PACÍFICOS DA ENERGIA NUCLEAR, CELEBRADO EM ARICA, REPÚBLICA DO CHILE, EM 20 DE MARÇO DE 2002.

\section{Decreto Legislativo 1018 de 11/11/05}

APROVA O TEXTO DO ACORDO REGIONAL DE COOPERAÇÃO PARA A PROMOÇÃO DA CIÊNCIA E DA TECNOLOGIA NUCLEAR NA AMÉRICA LATINA E NO CARIBE - ARCAL, CELEBRADO NO ÂMBITO DA AGÊNCIA INTERNACIONAL DE ENERGIA ATÔMICA - AIEA, ASSINADO EM VIENA, EM 25 DE SETEMBRO DE 1998.

Decreto Legislativo 787 de 08/07/05

APROVA O TEXTO DO ACORDO ENTRE O GOVERNO DA REPÚBLICA FEDERATIVA DO BRASIL E O GOVERNO DA REPÚBLICA DA CORÉIA PARA COOPERAÇÃO NOS USOS PACÍFICOS DA ENERGIA NUCLEAR, CELEBRADO EM SEUL, EM 18 DE JANEIRO DE 2001.

\section{Decreto Legislativo 770 de 30/06/05}

APROVA O TEXTO DO ACORDO DE COOPERAÇÃO ENTRE O GOVERNO DA REPÚBLICA FEDERATIVA DO BRASIL E O GOVERNO DA REPÚBLICA FRANCESA PARA O DESENVOLVIMENTO DAS UTILIZAÇÕES PACÍFICAS DA ENERGIA NUCLEAR, CELEBRADO EM 25 DE OUTUBRO DE 2002, EM PARIS. 


\section{Decreto Legislativo 67 de 25/08/99}

APROVA O TEXTO DO ACORDO DE COOPERAÇÃO SOBRE OS USOS PACIFICOS DA ENERGIA NUCLEAR, CELEBRADO ENTRE O GOVERNO DA REPUBLICA FEDERATIVA DO BRASIL E O GOVERNO DOS ESTADOS UNIDOS DA AMERICA, EM BRASILIA, EM 14 DE OUTUBRO DE 1997.

\section{Decreto Legislativo 65 de 02/07/98}

APROVA O TEXTO DO TRATADO SOBRE A NÃO-PROLIFERAÇÃO DE ARMAS NUCLEARES, CONCLUIDO EM 1 DE JULHO DE 1968, COM VISTAS A ADESÃO PELO GOVERNO BRASILEIRO.

\section{Decreto Legislativo 64 de 02/07/98}

APROVA O TEXTO DO TRATADO DE PROIBIÇÃO COMPLETA DE TESTES NUCLEARES - CTBT, CONCLUIDO EM NOVA IORQUE, EM 24 DE SETEMBRO DE 1996.

\section{Decreto Legislativo 9 de 28/01/97}

APROVA O TEXTO DO ACORDO PARA COOPERAÇÃO NOS USOS PACIFICOS DA ENERGIA NUCLEAR, CELEBRADO ENTRE O GOVERNO DA REPUBLICA FEDERATIVA DO BRASIL E O GOVERNO DO CANADA, EM BRASILIA, EM 22 DE MAIO DE 1996.

\section{Decreto Legislativo 4 de 22/01/97}

APROVA O TEXTO DA CONVENÇÃO DE SEGURANÇA NUCLEAR, ASSINADA PELO BRASIL EM 20 DE SETEMBRO DE 1994. 
Decreto Legislativo 190 de 15/12/95

APROVA O TEXTO DO ACORDO PARA COOPERAÇÃO NOS USOS PACIFICOS DA ENERGIA NUCLEAR, CELEBRADO ENTRE O GOVERNO DA FEDERAÇÃO DO BRASIL E O GOVERNO DA FEDERAÇÃO DA RUSSIA, EM BRASILIA, EM 15 DE SETEMBRO DE 1994.

\section{Decreto Legislativo 29 de 13/12/94}

APROVA A ALTERAÇÃO DE CONTRATO DE EMPRESTIMO ACORDADA ENTRE FURNAS CENTRAIS ELETRICAS S.A. E UM CONSORCIO DE BANCOS ALEMÃES, PARA TRANSFERIR RECURSOS FINANCEIROS DESTINADOS A CONSTRUÇÃO DE USINA NUCLEAR ANGRA III PARA A USINA NUCLEAR ANGRA II, E CRIA COMISSÃO DE AVALIAÇÃO DAS ATIVIDADES DO SETOR NUCLEAR.

\section{Decreto Legislativo 19 de 13/05/94}

APROVA OS TEXTOS DAS RESOLUÇÕES 267(E-V) E 268(XII) DA CONFERENCIA GERAL DO ORGANISMO PARA A PROSCRIÇÃO DAS ARMAS NUCLEARES NA AMERICA LATINA E NO CARIBE (OPANAL), QUE ALTERAM, RESPECTIVAMENTE, A DENOMINAÇÃO LEGAL DO TRATADO PARA A PROSCRIÇÃO DAS ARMAS NUCLEARES NA AMERICA LATINA E O PARAGRAFO 2 DE SEU ARTIGO 25, BEM COMO O TEXTO EMENDADO DO REFERIDO TRATADO.

\section{Decreto Legislativo 13 de 03/03/94}

APROVA O TEXTO DO ACORDO ENTRE O GOVERNO DA REPUBLICA FEDERATIVA DO BRASIL E A AGENCIA BRASILEIRO-ARGENTINA DE CONTABILIDADE E CONTROLE DE MATERIAIS NUCLEARES - ABACC SOBRE SUAS OBRIGAÇÕES, PRIVILEGIOS E IMUNIDADES, FIRMADO EM BRASILIA, EM 27 DE MARÇO DE 1992. 


\section{Decreto Legislativo 11 de 09/02/94}

APROVA O TEXTO DO ACORDO ENTRE A REPUBLICA FEDERATIVA DO BRASIL, A REPUBLICA ARGENTINA, A AGENCIA BRASILEIRO-ARGENTINA DE CONTABILIDADE E CONTROLE DE MATERIAIS NUCLEARES - ABACC E AGENCIA INTERNACIONAL DE ENERGIA ATOMICA - AIEA PARA APLICAÇÃO DE SALVAGUARDAS, FIRMADO EM VIENA, EM 13 DE DEZEMBRO DE 1991.

\section{Decreto Legislativo 02 de 23/03/93}

APROVA O TEXTO DO ACORDO DE COOPERAÇÃO NO CAMPO DOS USOS PACIFICOS DA ENERGIA NUCLEAR ENTRE O GOVERNO DA REPUBLICA FEDERATIVA DO BRASIL E O GOVERNO DA ESPANHA, CELEBRADO EM BRASILIA, A 12 DE MAIO DE 1983.

\section{Decreto Legislativo 223 de 12/12/91}

APROVA O ATO TEXTO DO ACORDO DE COOPERAÇÃO NA AREA DE ENERGIA NUCLEAR PARA FINS PACIFICOS ENTRE O GOVERNO DA REPUBLICA FEDERATIVA DO BRASIL E O GOVERNO DA REPUBLICA DA VENEZUELA, CONCLUIDO EM CARACAS, A 30 DE NOVEMBRO DE 1983.

\section{Decreto Legislativo 221 de 11/12/91}

APROVA O TEXTO DO ACORDO PARA O USO EXCLUSIVAMENTE PACIFICO DA ENERGIA NUCLEAR, ASSINADO EM GUADALAJARA, EM 18 DE JULHO DE 1991, BEM COMO O TEXTO DO PROTOCOLO ADICIONAL SOBRE PRIVILEGIOS E IMUNIDADES DO ACORDO EM EPIGRAFE, FIRMADO EM BRASILIA, EM 20 DE AGOSTO DE 1991 - OS DOIS CELEBRADOS ENTRE O GOVERNO DA REPUBLICA FEDERATIVA DO BRASIL E O GOVERNO DA REPUBLICA DA ARGENTINA. 


\section{Decreto Legislativo 24 de 29/08/90}

APROVAM OS TEXTOS DA CONVENÇÃO SOBRE PRONTA NOTIFICAÇÃO DE ACIDENTE NUCLEAR E DA CONVENÇÃO SOBRE ASSISTENCIA NO CASO DE ACIDENTE NUCLEAR OU EMERGENCIA RADIOLOGICA, APROVADAS DURANTE A SESSÃO ESPECIAL DA CONFERENCIA GERAL DA AGENCIA INTERNACIONAL DE ENERGIA ATOMICA - AIEA, EM VIENA, DE 24 A 27 DE SETEMBRO DE 1986.

\section{Decreto Legislativo 02 de 11/02/88}

APROVA O TEXTO DO TRATADO SOBRE A PROIBIÇÃO DE COLOCAÇÃO DE ARMAS NUCLEARES E OUTRAS DE DESTRUIÇÃO EM MASSA NOS FUNDOS MARINHOS E LEITOS OCEANICOS E NOS SEUS SUBSOLOS, CONCLUIDO A 11 DE FEVEREIRO DE 1971, NAS CIDADES DE MOSCOU, LONDRES E WASHINGTON, E ASSINADO PELO BRASIL A 3 DE SETEMBRO DE 1971.

\section{Decreto Legislativo 12 de 25/11/87}

APROVA O TEXTO DO ACORDO DE COOPERAÇÃO NO CAMPO DOS USOS PACIFICOS DA ENERGIA NUCLEAR, CELEBRADO ENTRE O GOVERNO DA REPUBLICA FEDERATIVA DO BRASIL E O GOVERNO DA REPUBLICA POPULAR DA CHINA, EM PEQUIM, A 11 DE OUTUBRO DE 1984.

\section{Decreto Legislativo 03 de 09/04/85}

DETERMINA QUE SEJAM SUBMETIDOS À APROVAÇÃO DO CONGRESSO NACIONAL TODOS OS AJUSTES, ATOS E CONTRATOS COMPLEMENTARES AO ACORDO SOBRE COOPERAÇÃO NO CAMPO DOS USOS PACIFICOS DA ENERGIA NUCLEAR, ASSINADO ENTRE A REPUBLICA FEDERATIVA DO BRASIL E A REPUBLICA FEDERAL DA ALEMANHA, EM BONN, A 27 DE JUNHO DE 1975. 


\section{Decreto Legislativo 50 de 27/11/84}

APROVA O TEXTO DA CONVENÇÃO SOBRE A PROTEÇÃO FISICA DO MATERIAL NUCLEAR, ASSINADO EM VIENA, A 15 DE MAIO DE 1981.

\section{Decreto Legislativo 55 de 16/08/83}

APROVA O TEXTO DO ACORDO DE COOPERAÇÃO CELEBRADO ENTRE O GOVERNO DA REPUBLICA FEDERATIVA DO BRASIL E O GOVERNO DA REPUBLICA ARGENTINA PARA O DESENVOLVIMENTO E A APLICAÇÃO DOS USOS PACIFICOS DA ENERGIA NUCLEAR, EM BUENOS AIRES, A 17 DE MAIO DE 1980.

\section{Decreto Legislativo 06 de 08/04/83}

APROVA O TEXTO DO ACORDO SOBRE OS USOS PACIFICOS DA ENERGIA NUCLEAR, ASSINADO ENTRE OS GOVERNOS DA REPUBLICA FEDERATIVA DO BRASIL E DA REPUBLICA DA COLOMBIA, EM BOGOTA, A 12 DE MARÇO DE 1981.

\section{Decreto Legislativo 113 de 02/12/82}

APROVA O TEXTO DO ACORDO DE COOPERAÇÃO NO CAMPO DOS USOS PACIFICOS DA ENERGIA NUCLEAR, FIRMADO ENTRE O GOVERNO DA REPUBLICA FEDERATIVA DO BRASIL E O GOVERNO DA REPUBLICA DO PERU, EM LIMA, A 26 DE JUNHO DE 1981.

\section{Decreto Legislativo 61 de 21/10/81}

APROVA O TEXTO DO DECRETO-LEI 1.865, DE 26 DE FEVEREIRO DE 1981, QUE 'DISPÕE SOBRE A OCUPAÇÃO PROVISORIA DE IMOVEIS PARA PESQUISA E LAVRA DE SUBSTANCIAS MINERAIS QUE CONTENHAM ELEMENTOS NUCLEARES'. 


\section{Decreto Legislativo 49 de 01/10/81}

APROVA O TEXTO DO ACORDO SOBRE OS USOS PACIFICOS DA ENERGIA NUCLEAR, CONCLUIDO ENTRE O GOVERNO DA REPUBLICA FEDERATIVA DO BRASIL E O GOVERNO DA REPUBLICA DO IRAQUE, A 5 DE JANEIRO DE 1980.

\section{Decreto Legislativo 04 de 26/03/81}

APROVA O TEXTO DO DECRETO-LEI 1.809, DE 7 DE OUTUBRO DE 1980, QUE 'INSTITUI O SISTEMA DE PROTEÇÃO AO PROGRAMA NUCLEAR BRASILEIRO, E DA OUTRAS PROVIDENCIAS'.

\section{Decreto Legislativo 61 de 21/09/78}

APROVA O TEXTO DO DECRETO-LEI 1.630, DE 17 DE JULHO DE 1978, QUE CONCEDE BENEFICIOS TRIBUTARIOS AO PROGRAMA NUCLEAR BRASILEIRO E DA OUTRAS PROVIDENCIAS.

\section{Decreto Legislativo 36 de 11/05/77}

APROVA O TEXTO DO DECRETO-LEI 1.511, DE 28 DE DEZEMBRO DE 1976, QUE ALTERA A REDAÇÃO DO ARTIGO 1 DO DECRETO-LEI 343, DE 28 DEZEMBRO DE 1967.

\section{Decreto Legislativo 85 de 20/10/75}

APROVA O TEXTO DO ACORDO SOBRE COOPERAÇÃO NO CAMPO DOS USOS PACIFICOS DA ENERGIA NUCLEAR, ASSINADO ENTRE A REPUBLICA FEDERATIVA DO BRASIL E A REPUBLICA FEDERAL DA ALEMANHA, EM BONN, A 27 DE JUNHO DE 1975. 


\section{Decreto Legislativo 72 de 28/11/72}

APROVA O TEXTO DO CONVENIO SOBRE A ENTRADA DE NAVIOS NUCLEARES EM AGUAS BRASILEIRAS E SUA PERMANENCIA EM PORTOS BRASILEIROS, CELEBRADO, ENTRE OS GOVERNOS DA REPUBLICA FEDERATIVA DO BRASIL E DA REPUBLICA FEDERAL DA ALEMANHA, EM BRASILIA, A 7 DE JUNHO DE 1972.

\section{Decreto Legislativo 49 de 14/09/72}

APROVA O TEXTO DO ACORDO DE COOPERAÇÃO ENTRE O GOVERNO DA REPUBLICA FEDERATIVA DO BRASIL E O GOVERNO DOS ESTADOS UNIDOS DA AMERICA REFERENTE AOS USOS CIVIS DA ENERGIA ATOMICA, CELEBRADO EM WASHINGTON, A 17 DE JULHO DE 1972, E O TEXTO DA EMENDA AO ACORDO ENTRE A AGENCIA INTERNACIONAL DE ENERGIA ATOMICA, O GOVERNO DA REPUBLICA FEDERATIVA DO BRASIL E O GOVERNO DOS ESTADOS UNIDOS DA AMERICA PARA A APLICAÇÃO DE SALVAGUARDAS, FIRMADO EM VIENA, A 27 DE JULHO DE 1972.

\section{Decreto Legislativo 70 de 22/10/70}

APROVA O TEXTO DO ACORDO SOBRE COOPERAÇÃO NO CAMPO DOS USOS PACIFICOS DA ENERGIA ATOMICA, ENTRE A REPUBLICA FEDERATIVA DO BRASIL E A REPUBLICA DO EQUADOR, FIRMADO EM QUITO, A 11 DE JUNHO DE 1970 .

\section{Decreto Legislativo 44 de 15/10/68}

APROVA O TEXTO DO ACORDO PARA A APLICAÇÃO DE SALVAGUARDAS ASSINADO EM VIENA, A 10 DE MAIO DE 1967, ENTRE A REPUBLICA FEDERATIVA DO BRASIL E OS ESTADOS UNIDOS DA AMERICA E A AGENCIA INTERNACIONAL DE ENERGIA ATOMICA. 


\section{Decreto Legislativo 11 de 12/03/68}

APROVA O TEXTO DO ACORDO SOBRE COOPERAÇÃO NO CAMPO DOS USOS PACIFICOS DA ENERGIA ATOMICA, ENTRE O BRASIL E A REPUBLICA DO PERU, ASSINADO EM LIMA, A 30 DE NOVEMBRO DE 1966.

\section{Decreto Legislativo 51 de 30/11/67}

APROVA O ACORDO DE COOPERAÇÃO PARA A UTILIZAÇÃO DA ENERGIA ATOMICA PARA FINS PACIFICOS ENTRE O BRASIL E A CONFEDERAÇÃO DA SUIÇA, ASSINADO NO RIO DE JANEIRO, A 26 DE MAIO DE 1965.

\section{Decreto Legislativo 50 de 30/11/67}

APROVA O TRATADO PARA A PROSCRIÇÃO DE ARMAS NUCLEARES, NA AMERICA LATINA, ASSINADO, NA CIDADE DO MEXICO, EM 09 DE MAIO DE 1967.

\section{Decreto Legislativo 49 de 30/11/67}

APROVA A EMENDA AO ARTIGO VI-A. 3 DO ESTATUTO DA AGENCIA INTERNACIONAL DE ENERGIA ATOMICA, ADOTADA A 4 DE OUTUBRO DE 1961, PELA CONFERENCIA GERAL DAQUELA AGENCIA, POR OCASIÃO DE SUA QUINTA SESSÃO REGULAR.

\section{Decreto Legislativo 38 de 26/10/67}

APROVA O TEXTO DO DECRETO-LEI 330, DE 13 DE SETEMBRO DE 1967, QUE REVOGA DISPOSITIVOS DO DECRETO-LEI 227, DE 28 DE FEVEREIRO DE 1967, ALTERADO PELO DECRETO-LEI 518, DE 14 DE MARÇO DE 1967 (CODIGO DE MINAS) E RESTAURA A VIGENCIA DO ARTIGO 33 DA LEI 4.118, DE 27 DE AGOSTO DE 1962, QUE TRATA DE CONCESSÃO DE LAVRA DE MINERAIS NUCLEARES. 


\section{Decreto Legislativo 35 de 26/09/67}

APROVA O ACORDO ENTRE O GOVERNO BRASILEIRO E O GOVERNO DA REPUBLICA PORTUGUESA PARA A COOPERAÇÃO NA UTILIZAÇÃO DA ENERGIA NUCLEAR PARA FINS PACIFICOS, ASSINADA NO RIO DE JANEIRO, EM 18 DE JUNHO DE 1965.

\section{Decreto Legislativo 68 de 30/11/66}

APROVA O ACORDO SOBRE COOPERAÇÃO NO CAMPO DOS USOS PACIFICOS DA ENERGIA ATOMICA, CELEBRADO ENTRE A REPUBLICA DOS ESTADOS UNIDOS DO BRASIL E A REPUBLICA DA BOLIVIA, EM 11 DE JANEIRO DE 1966.

\section{Decreto Legislativo 48 de 04/10/66}

APROVA O ACORDO DE COOPERAÇÃO PARA USOS CIVIS DA ENERGIA ATOMICA, ENTRE O GOVERNO DOS ESTADOS UNIDOS DA AMERICA E O GOVERNO DOS ESTADOS UNIDOS DO BRASIL, ASSINADO EM WASHINGTON, A 08.07 .65 .

\section{Decreto Legislativo 11 de 25/04/66}

APROVA O ACORDO BASICO DE ASSISTENCIA TECNICA, ASSINADO EM 29.12.64, NA CIDADE DO RIO DE JANEIRO, ENTRE O GOVERNO DOS ESTADOS UNIDOS DO BRASIL, A ORGANIZAÇÃO DAS NAÇÕES UNIDAS E OUTROS ORGANISMOS INTERNACIONAIS.

\section{Decreto Legislativo 42 de 21/05/65}

APROVA O TEXTO DO ACORDO DE COOPERAÇÃO NO CAMPO DAS UTILIZAÇÕES PACÍFICAS DA ENERGIA ATOMICA, ENTRE O GOVERNO DOS ESTADOS UNIDOS DO BRASIL E A COMUNIDADE EUROPEIA DE ENERGIA ATOMICA (EURATOM) FIRMADO EM BRASILIA, A 09 DE JUNHO DE 1961. 


\section{Decreto Legislativo 30 de 05/08/64}

APROVA O TRATADO DE PRESCRIÇÃO DAS EXPERIENCIAS COM ARMAS NUCLEARES NA ATMOSFERA, NO ESPAÇO COSMICO E SOB A AGUA, FIRMADO PELO BRASIL EM MOSCOU A 9 DE AGOSTO DE 1963.

\section{Decreto Legislativo 33 de 16/12/63}

APROVA O TEXTO DO ACORDO DE COOPERAÇÃO SOBRE UTILIZAÇÃO DA ENERGIA ATOMICA PARA FINS PACIFICOS, CELEBRADO ENTRE OS ESTADOS UNIDOS DO BRASIL E A REPUBLICA FRANCESA, A 2 DE MAIO DE 1962, NA CIDADE DO RIO DE JANEIRO.

\section{Decreto Legislativo 14 de 23/11/62}

APROVA O ACORDO SOBRE COOPERAÇÃO NO CAMPO DOS USOS PACIFICOS DA ENERGIA ATOMICA ENTRE OS ESTADOS UNIDOS DO BRASIL E A REPUBLICA DO PARAGUAI FIRMADO EM ASSUNÇÃO A 18 DE AGOSTO DE 1961.

\section{Decreto Legislativo 13 de 23/11/62}

APROVA O ACORDO DE COOPERAÇÃO ENTRE OS ESTADOS UNIDOS DO BRASIL E A REPUBLICA ITALIANA PARA USO PACÍFICO DA ENERGIA NUCLEAR, FIRMADO NO RIO DE JANEIRO A 6 DE SETEMBRO DE 1958.

\section{Decreto Legislativo 24 de 24/07/57}

APROVA O ESTATUTO DA AGENCIA INTERNACIONAL DE ENERGIA ATOMICA. 


\section{LEI - Relação histórica com respectivos objetos}

Lei 10.463 de 23/05/02

ALTERA A SEDE E O FORO DA INDÚSTRIAS NUCLEARES DO BRASIL S.A - INB.

Lei 10.308 de 20/11/01

DISPÕE SOBRE A SELEÇÃO DE LOCAIS, A CONSTRUÇÃO, O LICENCIAMENTO, A OPERAÇÃO, A FISCALIZAÇÃO, OS CUSTOS, A INDENIZAÇÃO, A RESPONSABILIDADE CIVIL E AS GARANTIAS

REFERENTES AOS DEPÓSITOS DE REJEITOS RADIOATIVOS, E DÁ OUTRAS PROVIDÊNCIAS.

\section{Lei $\mathbf{n}^{0}$ 9.112, de 10.10 .95}

DISPÕE SOBRE A EXPORTAÇÃO DE BENS SENSÍVEIS E SERVIÇOS DIRETAMENTE VINCULADOS

Lei 9.765 de 17/12/98

INSTITUI TAXA DE LICENCIAMENTO, CONTROLE E FISCALIZAÇÃO DE MATERIAIS NUCLEARES E RADIOATIVOS E SUAS INSTALAÇÕES.

Lei 9.425 de 24/12/96

DISPÕE SOBRE A CONCESSÃO DE PENSÃO ESPECIAL AS VÍTIMAS DE ACIDENTE NUCLEAR OCORRIDO EM GOIANIA, GOIAS.

\section{Lei 9.112 de 10/10/95}

DISPÕE SOBRE A EXPORTAÇÃO DE BENS SENSIVEIS E SERVIÇOS DIRETAMENTE VINCULADOS. 


\section{Lei 7.915 de 07/12/89}

DISPÕE SOBRE A TRANSFERENCIA DAS AÇÕES REPRESENTATIVAS DO CAPITAL DA NUCLEBRAS ENGENHARIA S.A - NUCLEN, DA NUCLEBRAS EQUIPAMENTOS PESADOS S.A- NUCLEP E DO ACERVO DO CENTRO DE DESENVOLVIMENTO DE TECNOLOGIA NUCLEAR - CDTN, E DA OUTRAS PROVIDENCIAS.

\section{Lei 7.781 de 27/06/89}

DA NOVA REDAÇÃO AOS ARTIGOS 2, 10 E 19 DA LEI 6.189, DE 16 DE DEZEMBRO DE 1974, E DA OUTRAS PROVIDENCIAS.

\section{Lei 6.571 de 30/09/78}

DISPÕE SOBRE O REGIME JURIDICO DO PESSOAL DA COMISSÃO NACIONAL DE ENERGIA NUCLEAR- CNEN E DA OUTRAS PROVIDENCIAS.

\section{Lei 6.453 de 17/10/77}

DISPÕE SOBRE A RESPONSABILIDADE CIVIL POR DANOS NUCLEARES E A RESPONSABILIDADE CRIMINAL POR ATOS RELACIONADOS COM ATIVIDADES NUCLEARES E DÁ OUTRAS PROVIDÊNCIAS.

\section{Lei 6.189 de 16/12/74}

ALTERA A LEI No 4.118, DE 27 DE AGOSTO DE 1962, E A LEI N 5.740, DE 1 DE DEZEMBRO DE 1971, QUE CRIARAM, RESPECTIVAMENTE, A COMISSÃO NACIONAL DE ENERGIA NUCLEAR -CNEN E A COMPANHIA BRASILEIRA DE TECNOLOGIA NUCLEAR- CBTN, QUE PASSA A DENOMINAR-SE EMPRESAS NUCLEARES BRASILEIRAS SOCIEDADE ANÔNIMA - NUCLEBRÁS, E DÁ OUTRAS PROVIDÊNCIAS. 
Lei 5.942 de 29/11/73

DENOMINA DE 'ALMIRANTE ALVARO ALBERTO' A CENTRAL NUCLEAR DE ANGRA DOS REIS, LOCALIZADA NO ESTADO DO RIO DE JANEIRO.

\section{Lei 5.877 de 11/05/73}

AUTORIZA A COMISSÃO NACIONAL DE ENERGIA NUCLEAR - CNEN A INTEGRALIZAR PARCIALMENTE O CAPITAL SOCIAL AUTORIZADO DA COMPANHIA BRASILEIRA DE TECNOLOGIA NUCLEAR - CBTN.

\section{Lei 5.740 de 01/12/71}

AUTORIZA A COMISSÃO NACIONAL DE ENERGIA NUCLEAR - CNEN A CONSTITUIR A SOCIEDADE POR AÇÕES COMPANHIA BRASILEIRA DE TECNOLOGIA NUCLEAR- CBTN, E DÁ OUTRAS PROVIDÊNCIAS.

\section{Lei 5.299 de 23/06/67}

DISPÕE SOBRE A CONTRATAÇÃO DE PESSOAL TECNICO ESPECIALIZADO DE NIVEL MEDIO E SUPERIOR PELA COMISSÃO NACIONAL DE ENERGIA NUCLEAR - CNEN E DA OUTRAS PROVIDENCIAS.

\section{Lei 4.857 de 25/11/65}

AUTORIZA O PODER EXECUTIVO A ABRIR, PELA COMISSAO NACIONAL DE ENERGIA NUCLEAR - CNEN, O CREDITO ESPECIAL DE CR 3.170.703.600,00 (TRES BILHOES, CENTO E SETENTA MILHOES, SETECENTOS E TRES MIL E SEISCENTOS CRUZEIROS), PARA ATENDER AO PAGAMENTO DAS DESPESAS COM A DESAPROPRIACAO DO ACERVO DOS BENS PERTENCENTES À ORQUIMA - INDÚSTRIAS QUIMICAS REUNIDAS S/A, SITUADOS NA CAPITAL DO ESTADO DE SAO PAULO, DESTINADOS A INDUSTRIALIZACAO DA MONAZITA AMBLIGONITA E ZIRCONITA. 


\section{Lei 4.156 de 28/11/62}

ALTERA A LEGISLAÇÃO SOBRE O FUNDO FEDERAL DE ELETRIFICAÇÃO E DA OUTRAS PROVIDENCIAS.

\section{Lei 4.118 de 27/08/62}

DISPÕE SÔBRE A POLÍTICA NACIONAL DE ENERGIA NUCLEAR, CRIA A COMISSÃO NACIONAL DE ENERGIA NUCLEAR - CNEN, E DÁ OUTRAS PROVIDÊNCIAS.

\section{Lei 3.730 de 04/03/60}

AUTORIZA O PODER EXECUTIVO A ABRIR, PELO MINISTERIO DA FAZENDA O CREDITO ESPECIAL DE CR 976.700.000,00 DESTINADO AO PAGAMENTO DE DESPESAS DA COMISSAO NACIONAL DE ENERGIA NUCLEAR- CNEN.

\section{Lei 3.541 de 02/02/59}

AUTORIZA O PODER EXECUTIVO A ABRIR PELO MINISTERIO DA FAZENDA, O CREDITO ESPECIAL DE CR 736.000.000,00 PARA ATENDER AO PAGAMENTO DE DESPESAS NO EXERCICIO DE 1958, DA COMISSAO NACIONAL DE ENERGIA NUCLEAR- CNEN.

\section{Lei 3.332 de $05 / 12 / 57$}

AUTORIZA O PODER EXECUTIVO A ABRIR, PELO MINISTERIO DA FAZENDA, O CREDITO ESPECIAL DE CR 158.000.000,00 PARA ATENDER AS DESPESAS COM A INSTALACAO E FUNCIONAMENTO DA COMISSAO NACIONAL DE ENERGIA NUCLEAR- CNEN. 
Lei 1.303 de 31/12/50

CRIA, NO QUADRO PERMANENTE DO MINISTERIO DA EDUCAÇÃO E SAUDE, UM CARGO DE PROFESSOR CATEDRATICO DE FISICA NUCLEAR.

\section{Lei 1.234 de 14/11/50}

CONFEREM DIREITOS E VANTAGENS A SERVIDORES QUE OPERAM COM RAIOS X E SUBSTANCIAS RADIOATIVAS ${ }^{39-40}$. 


\section{GLOSSÁRIO}

Acidente: É quando a situação potencial que se torna real atingi a população e feri os seus limites de dose anuais primários e secundários, isto é, $1 \mathrm{mSv}$ se for irradiação de corpo inteiro.

Água-pesada: É o óxido de deutério de fórmula $\mathrm{D}_{2} \mathrm{O}$. É quimicamente semelhante à água normal, $\mathrm{H}_{2} \mathrm{O}$, porém com átomos de hidrogênio mais pesados denominados deutérios cujos núcleos atômicos contém um nêutron além do próton encontrado em todos os átomos de hidrogênio.É útil na indústria nuclear em conseqüência de sua capacidade de reduzir as energias de nêutrons rápidos para energias térmicas.

Ciclo do combustível nuclear: É uma série de processos envolvidos no preparo e recuperação de combustível para reatores nucleares de potência. Inclui mineração, refino, enriquecimento, fabricação de elementos combustíveis, uso no reator, processamentos químicos para recuperar e reconverter o material fissionável ainda existente no combustível usado e re-enriquecimento do material combustível para uso no ciclo seguinte.

Combustível nuclear: É o material físsil ou fissionável utilizado num reator nuclear para produzir energia. O termo é também usado para definir uma mistura como a do Urânio natural - na qual somente pequena parte dos átomos presentes é constituída de materiais físseis -, se esta mistura for capaz de manter uma reação em cadeia.

Comunicações de segurança: São as ligações internas e externas, estabelecidas pelos órgãos do SIPRON, com a finalidade de atender as suas necessidades de segurança.

Efluentes radioativos: São as substâncias resultantes do tratamento dado aos rejeitos e cuja concentração de material radioativo é tão pequena que não requer um novo tratamento, permitindo sua liberação de forma programada e controlada.

Energia nuclear: É a energia que o núcleo do átomo possui, mantendo prótons e nêutrons juntos. Pode ser liberada por uma reação nuclear de fissão ou por decaimento radioativo. 
Equipamento especificado: É o equipamento especialmente projetado ou preparado para o processamento, uso ou produção de material nuclear ou material especificado.

Equipamento vital: É o equipamento, sistema, dispositivo ou material cuja falha, destruição, remoção ou liberação é capaz de, direta ou indiretamente, provocar uma situação de emergência.

Exposição: É o ato ou condição de estar submetido à radiação ionizante.

Exposição anormal: É qualquer ocorrência de exposição não previsível com certeza virtual, mas que tem uma previsão de que possa ocorrer, ainda que ela seja indesejável. Ela é expressa por uma probabilidade de ocorrência por ano e uma dose previsível de ocorrer.

Exposição normal: É aquela previsível de ocorrer com virtual certeza durante o trabalho normal da instalação que opera com fonte de radiação. Porém, ela também engloba as exposições anormais que tenham probabilidade previsível de ocorrência igual ou maior do que $10^{2} \mathrm{a}^{-1}$. As exposições normais obrigatoriamente devem obedecer aos padrões de radioproteção pertinentes. São considerados padrões de proteção radiológica os seguintes:
a) Limites de dose anuais básicos primários;
b) Limites de dose anuais básicos secundários;
c) Restrições de dose;
d) Doses de radiação autorizadas;
e) Doses de radiação otimizadas e
f) Níveis de referência.

Exposição potencial: Se elas se tornarem reais constituem-se no que se convencionou chamar de incidente ou acidente nuclear ou radiológico dependendo se ela ocorreu em instalações do ciclo do combustível nuclear, incluindo os reatores, ou se ocorreu em instalações radiativas, isto é, demais instalações não incluídas no ciclo do combustível.

Fonte de radiação: É qualquer objeto que causa exposição à radiação ionizante, tanto pela emissão de radiação ionizante como pela liberação de substâncias ou materiais radioativos. Por exemplo, materiais que emitem o radônio são fontes que se encontram no meio ambiente (ex: cimento), uma unidade de irradiação gama de esterilização é uma fonte na 
prática de preservação de alimentos por radiação, uma máquina de raios $\mathrm{X}$ pode ser uma fonte para a prática de radiodiagnóstico e uma instalação de potência nuclear é uma fonte na prática de geração de eletricidade por meio de potência nuclear. Uma instalação complexa ou múltipla situada numa localidade ou num sítio pode, quando apropriado, ser considerada uma única fonte para os propósitos da aplicação dos padrões de proteção e segurança.

Força de apoio: São consideradas forças de apoio a Organização Militar das Forças Armadas, Organização Policial-Militar ou de Bombeiros Militares, Repartições da Polícia Federal, da Polícia Civil Estadual e de outras Polícias, que tenham jurisdição na área em que a proteção física se faça necessária e que sejam capazes de apoiar o Sistema.

Fusão nuclear: A fusão nuclear é um processo de produção de energia que consiste na fusão dos núcleos de dois átomos leves (como, por exemplo, o Hidrogénio, o Hélio, o Deutério ou o Trítio) para formarem elementos mais pesados, com redução da massa dos reagentes.

Gamagrafia: É o processo de impressão de radiação gama em filme fotográfico. A gamagrafia industrial é a radiografia de peças metálicas.

Incidente: É quando a exposição potencial que se torna real permanece confinada na área de propriedade da instalação e, portanto, infringi unicamente os limites de dose primários e secundários anuais dos trabalhadores.

Instalação nuclear: É a instalação na qual o material nuclear é produzido, processado, reprocessado, utilizado, manuseado ou estocado em quantidades relevantes, assim compreendidos:

a) reator nuclear;

b) usina que utilize combustível nuclear para a produção de energia térmica ou elétrica para fins industriais;

c) fábrica ou usina para a produção ou tratamento de materiais nucleares, integrante do ciclo do combustível nuclear;

d) usina de reprocessamento de combustível nuclear irradiado; e 
e) depósito de materiais nucleares, não incluindo local de armazenamento temporário usado durante os transportes.

Instalação radioativa: É o local onde se produzem, utilizam, transportam ou armazenam fontes de radiação; excetuam-se desta definição:

a) as instalações nucleares;

b) os veículos transportadores de fontes de radiação quando essas não são parte integrante dos mesmos.

Inteligência: São as atividades que versem sobre a produção e à proteção dos conhecimentos acerca da energia nuclear considerados de interesse do Estado, particularmente os que envolvam projeto, atividade ou instalação nuclear.

Material especificado: É o material especialmente preparado para o processamento, uso ou produção de material nuclear.

Material nuclear: São os elementos nucleares ou seus subprodutos definidos na Lei n. ${ }^{\circ}$ 4.118, de 27 de agosto de 1962.

Material radiativo: É o material emissor de qualquer radiação eletromagnética ou particulada, direta ou indiretamente ionizante.

Mcmahon-act: No período imediatamente após a segunda guerra mundial, o método e o grau em que o governo controlaria materiais nucleares e de conhecimento foi amplamente debatida. A Lei de Energia Atômica de 1946, também conhecida como a Lei McMahon, decidiu em favor do controle civil, mas continuou um estrito monopólio público em ambos os conhecimentos científicos e tecnológicos, e de materiais cindíveis.

Plano de emergência: É o conjunto de medidas a serem implementadas em caso de situação potencial ou real de acidente.

Programa Nuclear Brasileiro: É conjunto dos projetos e atividades relacionados com a utilização da energia nuclear, segundo orientação, controle e supervisão do Governo Federal. 
Proteção: Entende-se como proteção aquela efetuada em condições normais de trabalho onde há o respeito aos padrões fixados para este propósito. A proteção pode ser realizada na própria fonte, diz-se relativa à fonte geralmente por blindagens adequadas. Pode também ser realizada no meio ambiente, isto é, o ambiente no qual a radiação se difunde até alcançar o indivíduo. Neste caso, a proteção é realizada suprimindo uma ou mais vias de transmissão do ambiente ou diminuindo o valor da radiação no percurso para alcançar o indivíduo. Por fim, podemos fornecer proteção ao individuo fornecendo equipamentos de proteção radiológica, interpondo barreiras entre ele e o meio ambiente ou ainda por controle remoto.

Proteção física: É o conjunto de medidas destinadas a evitar ato de sabotagem contra material, equipamento e instalação, a impedir a remoção não autorizada de material, em especial nuclear, e prover meios para rápida localização e recuperação de material desviado, e a defender o patrimônio e a integridade física do pessoal de uma unidade operacional.

Radiação: É a energia que se propaga através da matéria ou do espaço em forma de onda ou partícula.

Radiação ionizante: É qualquer radiação capaz de “arrancar” elétrons dos átomos, produzindo pares de íons em materiais biológicos.

Radiação natural: É a radiação existente no meio ambiente, proveniente de raios cósmicos, de elementos radioativos naturais, etc.

Radioatividade: É o decaimento espontâneo ou desintegração de um núcleo atômico instável.

Radiofármacos: São compostos radioativos para o uso in vivo no diagnóstico e terapia de "desordens" humanas.

Radioisótopos: É o isótopo radioativo. O isótopo instável de um elemento que decai ou se desintegra, emitindo radiação. 
Radioproteção: É o conjunto de medidas legais, técnicas e administrativas que visam a reduzir a exposição de seres vivos à radiação ionizante, a níveis tão baixos quanto razoavelmente exeqüível.

Rejeitos radioativos: É qualquer material resultante de atividades relacionadas à radionuclídeos (materiais radioativos) em quantidades superiores aos limites estabelecidos por normas da CNEN, para o qual a reutilização é imprópria ou não prevista. Comumente emprega-se a expressão lixo atômico como referência ao rejeito radioativo.

Resíduos radioativos: São aqueles materiais radioativos que serão armazenados e no futuro poderão ser reutilizados.

Salvaguardas nucleares: É o conjunto de medidas destinadas à proteção e ao controle de material nuclear, existente em qualquer planta ou instalação do chamado ciclo do combustível nuclear. Atividade que permite identificar, em tempo hábil, eventuais desvios de material nuclear, de forma a impedir sua utilização para fins não autorizados e a resguardar dado técnico cujo sigilo seja de interesse para o Estado no campo da utilização da energia nuclear. A base legal das Salvaguardas provém de normas e acordos internacionais e do preceito constitucional que trata do uso exclusivamente pacífico da energia nuclear.

Segurança: É uma "proteção" destinada a evitar, detectar e tomar as primeiras medidas em situações anormais de operação da fonte, isto é, destina-se a exposições potenciais. Estas são definidas como aquelas exposições que não são esperadas de serem recebidas com certeza, mas que podem resultar de um acidente em uma fonte ou devido a um evento ou seqüência de eventos com uma natureza probabilística, incluindo falhas de equipamento e erros operacionais (falhas humanas). A segurança é considerada separadamente da proteção, isto é, fonte, meio ambiente e indivíduo. No caso da segurança e proteção é realizada por meio do que se convencionou chamar de "em profundidade", isto é, a colocação de múltiplas barreiras em distâncias diferentes entre a fonte e o indivíduo. Por exemplo, o reator de pesquisa IEA-R1 do IPEN tem como primeira barreira à piscina do reator, a segunda barreira são as paredes da piscina, como terceira o prédio do reator que é estanque, a quarta barreira é a portaria que dá acesso ao prédio do reator e laboratórios anexos e finalmente como quinta barreira a portaria geral do IPEN. 
Segurança nuclear: É o conjunto de medidas preventivas de caráter técnico incluídas no projeto, na construção, na manutenção e na operação de uma Unidade Operacional do SIPRON, destinadas a evitar a ocorrência de acidente ou a atenuar o efeito deste.

Seguridade: Abrange técnicas, teorias e práticas relacionadas aos sistemas que utilizam fonte de radiação e de proteção física das fontes de radiação, fazendo com que estes atuem de forma segura.

Separação isotópica: É a centrifugação utilizada em programas de desenvolvimento nuclear, para fins de enriquecimento de Urânio que tem dois isótopos principais, ${ }^{235} \mathrm{U}$ e ${ }^{238}$ U. O gás hexafluoreto de urânio pode ser centrifugado de modo a separar os dois isótopos: o ${ }^{238} \mathrm{U}$ é mais pesado e tende a depositar-se nas paredes da centrífuga, enquanto que o ${ }^{235} \mathrm{U}$ é extraído do centro da mesma.

Situação de emergência: É uma situação anormal de um projeto ou atividade do PNB que, a partir de um determinado momento, foge ao controle planejado e pretendido pelo órgão encarregado de sua execução, demandando a implementação do Plano de Emergência.

Tratado de Tlatelolco: Tratado para a proscrição das armas nucleares na América Latina e no Caribe, concluído na Cidade do México, em 14 de fevereiro de 1967, México.

Turn-key: Chave na mão em tradução livre é uma operação em que a empresa contratada fica obrigada a entregar a obra em condições de pleno funcionamento. O preço do serviço e o prazo para entrega são definidos no processo licitatório.

Unidade operacional: É a unidade cuja atividade se relaciona com a produção, utilização, processamento, reprocessamento, manuseio, transporte ou estocagem de materiais de interesse para o PNB.

Unidade de transporte: É o conjunto de meios de transporte, sob chefia única, quando utilizado em proveito de projeto, de atividade ou de instalação nuclear. 
Usina hidrelétrica de Serra da Mesa: É uma usina hidrelétrica localizada na Bacia do Alto Tocantins, em Goiás, possui grande importância no panorama energético brasileiro. Um aspecto que a diferencia das demais obras do setor é o fato de ela ser fruto de parceria com a iniciativa privada. Por meio de estudos realizados junto ao DNAEE (Departamento Nacional de Águas e Energia Elétrica) e Eletrobrás, o Governo Federal iniciou, em 1993, o programa que unia uma empresa estatal e o setor privado. Serra da Mesa Energia S.A. foi a empresa vencedora do Processo de Seleção de Parceiros. A ela coube a responsabilidade da conclusão da usina, recebendo, em contrapartida, 51,54\% da energia que Serra da Mesa produz.

Yellow cake: Durante as etapas do ciclo de fabricação e utilização do combustível nuclear, uma dessas etapas compreende a prospecção, mineração, extração e beneficiamento do minério de urânio, e tem como objetivo a obtenção de um concentrado de urânio na forma de diuranato de sódio, Na2U2O7, ou de amônio, (NH4)2U2O7, que é denominado genericamente de bolo amarelo, na prática é conhecido e denominado como yellow cake. 


\section{REFERÊNCIAS}

1 TENNENBAUM, J. Energia nuclear uma tecnologia feminina. 2. ed. Rio de Janeiro: Carpax Dei, 2007.

2 TENNENBAUM, J. A economia dos isótopos. Rio de Janeiro: Carpax Dei, 2007.

3 CARPES, M. M. A política nuclear brasileira no contexto das relações internacionais contemporâneas. Domínio tecnológico como estratégia de inserção internacional. 2006. Dissertação (Mestrado) - Pontifícia Universidade Católica do Rio de Janeiro, Rio de Janeiro.

4 COIMBRA, G. L. A história e o desenvolvimento da energia nuclear no Brasil. In: Nuclear Inter Jura'2001. Proceedings. Budapeste, 2001.

5 SANTOS, T.S.G.F. A política nuclear brasileira até 1964. 2007. Dissertação (Mestrado) - Pontifícia Universidade Católica de São Paulo, São Paulo.

6 BRASIL. Decreto-Lei No 2.464, de 31 de agosto de 1988. Altera a denominação da Empresas Nucleares Brasileiras S.A. - NUCLEBRAS transfere bens de sua propriedade e dá outras providências. Diário Oficial da União, de 1 de setembro de 1988. Seção I, p.16.793.

7 COMASE - Comitê Coordenador das Atividades de Meio Ambiente do Setor Elétrico. Legislação ambiental de interesse do setor elétrico: nível federal. Atualização de Carlos Frederico S. Menezes e Claudia Blanco de Dios. 3. ed. Rev. e atual. Rio de Janeiro: Eletrobrás, 2008. 199p.

8 BASTOS, C. R. Hermenêutica e interpretação constitucional. São Paulo: Celso Bastos Editor, 1997.

9 BRASIL, Constituição da República Federativa do Brasil. Vade Mecum. PINTO, A.L.T; SANTOS, M.C.V; WINDT, L.C. 3. ed. São Paulo: Saraiva, 2007.

10 MEIRELLES, H. L. Direito administrativo brasileiro. 32 ed., atual. São Paulo: Malheiros, 2006.

11 BRASIL. Lei No 4.118, de 27 de agosto de 1962. Dispõe sobre a política nacional de energia nuclear, cria a Comissão Nacional de Energia Nuclear, e dá outras providências. Diário Oficial da União, de 17 de setembro de 1962. Seção I, p. 9.701.

12 BRASIL. Lei № 6.189, de 16 de dezembro de 1974. Altera a Lei n. ${ }^{\circ} 4.118$, de 27 de agosto de 1962, e a Lei ${ }^{\circ} 5.740$, de 1 de dezembro de 1971, que criaram, respectivamente, a Comissão Nacional de Energia Nuclear - CNEN e a Companhia Brasileira de Tecnologia Nuclear-CBTN, que passa a denominar-se Empresas Nucleares Brasileiras Sociedade Anônima - NUCLEBRÁS, e dá outras providências. Diário Oficial da União, de 17 de dezembro de 1974. Seção 1, p.14493. 
13 BRASIL. Lei No 6.571. Dispõe sobre o regime jurídico do pessoal da Comissão Nacional de Energia Nuclear (CNEN) e dá outras providências. Diário Oficial da União, de 3 de outubro de 1978. Seção I, p. 16.033.

14 BRASIL. Lei $\mathrm{N}^{\mathrm{o}} 7.781$, de 27 de junho de 1989. Dá nova redação aos artigos $2^{\circ}, 10^{\circ} \mathrm{e}$ $19^{\circ}$ da Lei $n^{\circ} 6.189$, de 16 de dezembro de 1974, e dá outras providências. Diário Oficial da União, de 28 de junho de 1989. Seção I, p. 10.473.

15 BRASIL. Lei $n^{0} 5.740$, de 01 de dezembro de 1971. Autoriza a Comissão Nacional de Energia Nuclear (CNEN) a constituir a sociedade por ações Companhia Brasileira de Tecnologia Nuclear - C.B.T.N., e dá outras providências. Diário Oficial da União, de 2 de dezembro de 1971. Seção I, p.9.825.

16 BRASIL. Decreto-Lei No 2.464, de 31 de agosto de 1988. Altera a denominação da Empresas Nucleares Brasileiras S.A. - NUCLEBRAS, transfere bens de sua propriedade, e dá outras providências. Diário Oficial da União, de 1 de setembro de 1988. Seção I, p.16.793.

17 BRASIL. Decreto $N^{0} 76.805$, de 16 de dezembro de 1975. Autoriza a criação da Nuclebrás Equipamentos Pesados S.A. - NUCLEP, sociedade por ações, subsidiária da Empresas Nucleares Brasileiras S.A. - NUCLEBRÁS Diário Oficial da União, 17 de dezembro de 1975. Seção I, p.16.747.

18 BRASIL. Decreto sem número, de 23 de maio de 1997. Autoriza a cisão de FURNAS Centrais Elétricas S.A., altera o objeto social da NUCLEN Engenharia e Serviços S.A., autoriza a transferência da autorização para construção e operação da Central Nuclear Almirante Álvaro Alberto e dá outras providências. Diário Oficial da União, 24 de maio de 1997. Seção I.

19 BRASIL. Decreto sem número, de 23 de dezembro de 1997. Aprova alterações do Estatuto Social e da denominação da NUCLEN Engenharia e Serviços S.A. Diário Oficial da União, 26 de dezembro de 1997. Seção I.

20 BRASIL. Decreto $n^{\circ} 4.899$, de 26 de novembro de 2003. Aprova alterações no Estatuto Social da Eletrobrás Termonuclear S.A. - ELETRONUCLEAR, aprovado pelo Decreto de 23 de dezembro de 1997. Diário Oficial da União, 27 de novembro de 2003. Seção I.

21 BRASIL. Lei ${ }^{0} 10.308$, de 20 de novembro de 2001. Dispõe sobre a seleção de locais, a construção, o licenciamento, a operação, a fiscalização, os custos, a indenização, a responsabilidade civil e as garantias referentes aos depósitos de rejeitos radioativos, e dá outras providências. Diário Oficial da União, 21 de novembro de 2001. Seção I.

22 COMISSÃO NACIONAL DE ENERGIA NUCLEAR. Normas para Transporte de material radioativo - Resolução n. ${ }^{\circ}$ 13/1988 - D.O.U. 01/08/88.

23 COMISSÃO NACIONAL DE ENERGIA NUCLEAR. Normas para Transporte, Recebimento, Armazenagem e Manuseio de elementos combustiveis de usinas nucleoelétricas - Portaria DExI CENEN n. ${ }^{\circ}$ 02/1986 - Publicação D.O.U. de 29/10/86. 
24 BRASIL. Decreto-lei no ${ }^{\circ} .865$, de 26 de fevereiro de 1981. Dispõe sobre a ocupação provisória de imóveis para pesquisa e lavra de substâncias minerais que contenham elementos nucleares. Diário Oficial da União, 27 de fevereiro de 1981.

25 ALMEIDA, I. P. S. Avaliação de fatores que afetam a eficácia de órgãos reguladores: uma aplicação ao setor nuclear. 2005. Tese (Doutorado) - Universidade Federal do Rio de Janeiro, Rio de Janeiro.

26 COMISSÃO NACIONAL DE ENERGIA NUCLEAR. Normas para Licenciamento de Reatores de Potência - Resolução n. ${ }^{\circ}$ 06/1972 - D.O.U. 22/05/72.

27 COMISSÃO NACIONAL DE ENERGIA NUCLEAR. Normas Básicas de Proteção Radiológica - Resolução n. ${ }^{\circ}$ 06/1973 - D.O.U. 19/09/73.

28 COMISSÃO NACIONAL DE ENERGIA NUCLEAR. Normas para escolha de locais para instalação de reatores de potencia. Resolução n. ${ }^{\circ}$ 09/1969 - D.O.U. 31/07/69.

29 COMISSÃO NACIONAL DE ENERGIA NUCLEAR. Normas para escolha de locais para instalação de reatores de potencia. Resolução n. ${ }^{\circ}$ 11/1969 - D.O.U. 21/09/69.

30 INTERNATIONAL ATOMIC ENERGY AGENCY. Radiation Safety Infrastructure Appraisal (RaSIA) for Brazil. Vienna. 2006.

31 FONTAINE, P. A Europa em 12 lições. Luxemburgo: Serviço das Publicações Oficiais das Comunidades Europeias. 2003.

32 UNIÃO EUROPEIA. Tratado que institui a Comunidade Europeia. Jornal Oficial n. ${ }^{\circ}$ C 115 de 09 de maio de 2008.

33 VOLPI. A. Desafios políticos da união européia. 2006. Tese (Doutorado) - Pontifícia Universidade Católica de São Paulo, São Paulo.

34 LOBO, M.T.C. Ordenamento jurídico comunitário. Belo Horizonte : Del Rey, 1997.

35 FORTE, U. Comunidade econômica Europeia. (Direito das Comunidades Europeias e harmonização fiscal). São Paulo: Malheiros, 1994.

36 PROGRAMA INDICATIVO NUCLEAR: Comunidades Europeias. Portal Europa. Sínteses da legislação da UE. Bruxelas. 1995-2009. Disponível em: $<$ http://europa.eu/legislation_summaries/energy/nuclear_energy/127072_pt.htm>. Acesso em: 10 mar. 2009.

37 TRATADO QUE INSTITUI A COMUNIDADE EUROPEIA DA ENERGIA ATÔMICA (EURATOM). Comunidades Europeias. Portal Europa. Sínteses da legislação da UE. Bruxelas. 1995-2009. Disponível em:

$<\mathrm{http}$ ://europa.eu/legislation_summaries/energy/nuclear_energy/treaties_euratom_pt.ht m> Acesso em: 12 mar. 2009. 
38 JORNAL OFICIAL DA UNIÃO EUROPEIA. COM (2006) 844 (JO C 138 de 22.6.2007). COM (2007) 565 (JO C 256 de 27.10.2007). Base de dados em EUR-Lex. Disponível em: $<$ http://eur-lex.europa.eu/JOIndex.do?ihmlang=pt $>$ Acesso em: 15 mar. 2009.

39 PRESIDÊNCIA DA REPUBLICA FEDERATIVA DO BRASIL. Apresenta textos sobre a legislação brasileira. Disponível em:

$<$ http://www.presidencia.gov.br/legislacao>. Acesso em 27 nov. 2008.

40 ASSOCIAÇÃO BRASILEIRA DE DIREITO NUCLEAR. Legislação nuclear. Rio de Janeiro. ABDN, 1980. 


\section{BIBLIOGRAFIA RECOMENDADA}

1 ASPECTOS POLÍTICOS E ECONÔMICOS. Apêndice I (parte do documento de revisão do Programa Nuclear Brasileiro - comentários sobre a área nuclear). In: Angra III - Subsídios para a tomada de decisão. CNEN, 2005. 6p.

2 BATISTA, P. N. O Acordo Nuclear Brasil - República da Alemanha In: ALBUQUERQUE, A.G (org.). Sessenta anos de Política Externa (1930 - 1990) Prioridades, atores e políticas. São Paulo: NUPRI/USP, 2000. Vol. 4, p. 19-64.

3 BECHARA, F. R. Legislação especial. 2. ed. São Paulo: Saraiva, 2006.

4 BERMANN, C. Energia Nuclear no Brasil: uma história de controvérsia, risco e incertezas. In: MATTHES, F.; ROSENKRANZ, G; BERMANN, C. (org.). A energia nuclear em debate. Mitos, realidade e mudanças climáticas. Rio de Janeiro: Fundação Henrich Böll, 2005. p.140-152.

5 BRASIL NUCLEAR. A verdade sobre os rejeitos nucleares. Rio de Janeiro: ABEN, n. 31, jun. 2007.

6 BRASIL NUCLEAR. O novo ciclo da energia nuclear. Rio de Janeiro: ABEN, n. 23, abr. 2002.

7 CAMARGO, G. O fogo dos deuses: uma história da energia nuclear. Rio de Janeiro: Contraponto, 2006.

8 CIÊECIA HOJE. A energia nuclear e seus usos na sociedade São Paulo, v. 37, n. 220, out. 2005.

9 CHASSOT, W. C. F (org). Ata do Simpósio sobre a utilização da energia atômica para fins pacíficos no Brasil (cadernos SBPC 15,16,17). Rio de Janeiro: SBPC, 2006. 3 vols.

10 CHIMENTI, R.; Capez, F.; Rosa, M. F. E.; Santos, M. F. Curso de Direito Constitucional. 3. ed. São Paulo, 2006.

11 CLERY, D. Nuclear Industry Dares to Dream of a New Dawn. Science, Washington, EUA, v. 309, p. 1172-1175, 19 ago. 2005.

12 DANTAS, M. B. Tutela de urgência nas lides ambientais. São Paulo: Forense, 2006.

13 DE MELLO, C. A. B. Curso de Direito Administrativo. 21 ed. São Paulo: Malheiros Editores, 2006.

14 FILGUEIRAS, S. A. Indústria nuclear: estratégia tecnológica e parceria com um instituto de pesquisa. 2002. Tese (Doutorado) - Universidade de São Paulo, São Paulo.

15 FERNANDES, P.V. Impacto ambiental. São Paulo: RT, 2005.

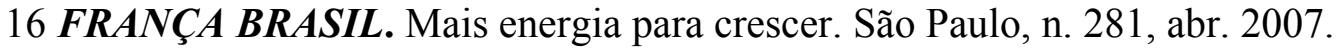


17 GOLDEMBERG, J. Energia, meio ambiente e desenvolvimento. São Paulo: USP, 2001.

18 GORDON, A. M. P. L. Um estudo de caso a luz da história da ciência, da tecnologia e da cultura brasileira. 2003. Tese (Doutorado) - Instituto de Pesquisas Energéticas e Nucleares, São Paulo.

19 GARCIA, J. C. V.; ROCHA FILHO, A. Renato Archer - Energia Atômica, Soberania e Desenvolvimento. Rio de Janeiro: Contraponto, 2006.

20 ISHIGURO, Y. A energia nuclear para o Brasil. São Paulo: Makron Books, 2002.

21 MILARÉ, E. Direito do ambiente. 4. ed. São Paulo: RT, 2005.

22 MONTANARI, V. Energia nossa de cada dia. São Paulo: Moderna, 2003.

23 PRADO, L. R. Direito Penal do ambiente. São Paulo: RT, 2005.

24 RIBEIRO, V. M. Tutela penal nas atividades nucleares. São Paulo: Revista dos Tribunais, 2004.

25 RODRIGUES, M. C.; Arantes, O. M. N. Direito Ambiental e biotecnologia. Curitiba: Juruá, 2004.

26 SANTOS, T. S. G. F. A política nuclear brasileira até 1964. 2007. Dissertação (Mestrado) - Pontifícia Universidade Católica de São Paulo, São Paulo.

27 SCIER, Paulo. Direito Constitucional anotações nucleares. São Paulo: Juruá, 2001.

28 SILVA, P. Vocabulário jurídico. 27 ed. Rio de Janeiro: Forense, 2006.

29 SORDI, G. M. A. A.; TODO, A. S. Fundamentos de tecnologia nuclear: proteção radiológica. São Paulo: IPEN, 2007. 31 p. Apostila.

30 WIGHT, Martin. A Política do Poder. Brasília: UnB, Instituto de Pesquisa de Relações Internacionais; São Paulo: Imprensa Oficial do Estado de São Paulo, 2002. 